Stratigraphy of the

Mascot-Jefferson City

Zinc District, Tennessee

GEOLOGIGAL SURVEY PROFESSIONAL PAPER 277

Prepared with the cooperation of the

Tennessee Department of Conservation,

Division of Geology

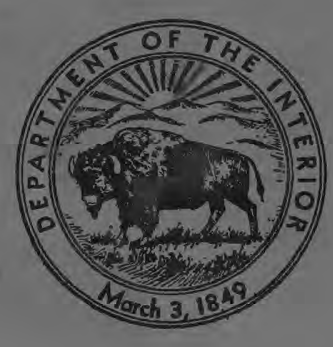




\section{Stratigraphy of the}

Mascot-Jefferson City

Zinc District, Tennessee

By JOSIAH BRIDGE

With an introduction by JOHN RODGERS

GEOLOGICAL SURVEY PROFESIONAL PAPER 277

Prepared with the cooperation of the

Tennessee Department of Conservation,

Division of Geology

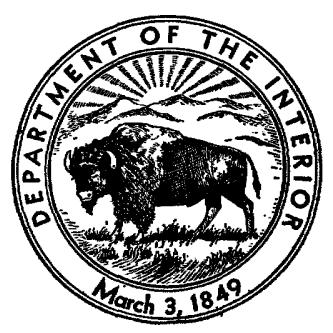


UNITED STATES DEPARTMENT OF THE INTERIOR

Douglas McKay, Secretary

GEOLOGIGAL SURVEY

W. E. Wrather, Director

For sale by the Superintendent of Documents, U. S. Government Printing Office Washington 25, D. C. 


\section{CONTENTS}

Abstract. . . Introduction, by John Rodgers Scope and purpose of the present report Work before 1929._. Recent work in the Knox group of East Tennessee.. The geologic map and mapping procedures.......Acknowledgments

Geography

Stratigraphy - .

Pre-Knox formations .....

Summary description Names and distribution Rome formation. Rutledge limestone.......

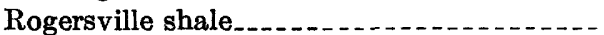
Maryville limestone......... Nolichucky shale Maynardville limestone member of Nolichucky shale.

General features.......

Facies relationships. .

Topographic expression

Paleontology and correlation..........

Knox group......

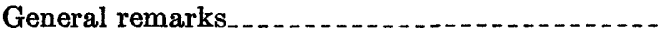

Definition

History

Present usage . .

Ozarkian and Canadian systems of Ulrich.-

Copper Ridge dolomite....

Name.

Distribution . .

Limits and thickness. ...

Bedrock lithology

Residual products................

Subdivisions...........

Facies relationships _...........

Paleontology and correlation.........

Chepultepec dolomite. . . . . . .

Name...

Limits_..............

Thickness

\begin{tabular}{|c|c|c|}
\hline Page & & Page \\
\hline 1 & Stratigraphy-Continued & \\
\hline 1 & Knox group-Continued & \\
\hline 1 & Chepultepec dolomite-Continued & \\
\hline 3 & Bedrock lithology & 38 \\
\hline 3 & Residual products. & 40 \\
\hline 5 & Facies relationships & 41 \\
\hline 5 & Paleontology and correlation & 41 \\
\hline 6 & Relation to the Longview dolomite & 45 \\
\hline 7 & Longview dolomite..... & 46 \\
\hline 7 & Name & 46 \\
\hline 7 & Limits_... & 47 \\
\hline 7 & Thickness_._. & 47 \\
\hline 8 & Bedrock lithology & 47 \\
\hline 8 & Residual products. & 48 \\
\hline 8 & Paleontology and correlation & 48 \\
\hline 10 & Kingsport limestone & 49 \\
\hline 10 & Name & 49 \\
\hline & Limits__-_. & 50 \\
\hline 11 & Thickness-1-. & 53 \\
\hline 17 & Bedrock lithology & 53 \\
\hline 17 & Correlation & 54 \\
\hline 18 & Mascot dolomite & 54 \\
\hline 19 & 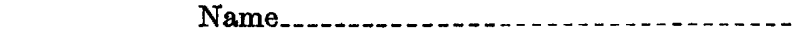 & 54 \\
\hline 21 & Limits and thickness. & 54 \\
\hline 21 & Bedrock lithology & 55 \\
\hline 21 & Correlation & $\mathbf{5 5}$ \\
\hline 21 & pression._. & 55 \\
\hline 23 & ations___ & 56 \\
\hline 24 & The name Chickamauga limestone & 56 \\
\hline 25 & Unconformity at base of Lenoir limestone & 57 \\
\hline 25 & Lenoir limestone._. & 59 \\
\hline 26 & Mosheim member & 59 \\
\hline 26 & Lenoir limestone exclusive of Mosheim & \\
\hline 30 & member.a.t. & 60 \\
\hline 31 & ' & 61 \\
\hline 33 & Appalachian Valley & 61 \\
\hline & Mascot belt & 61 \\
\hline 33 & Jefferson City belt & 62 \\
\hline 34 & Shields Ridge belt & 66 \\
\hline 37 & Mechanics of rock structure & 68 \\
\hline 37 & Economic generalizations & 69 \\
\hline 37 & ture cited... & 72 \\
\hline 38 & $x^{2}$ & 75 \\
\hline
\end{tabular}

III 


\section{ILLUSTRATIONS}

[All plates are in pocket]

Plate 1. Geologic map and sections of the Mascot-Jefferson City zinc mining district, Tennessee.

2. Map showing the relation of the Mascot-Jefferson City area to the main structural features of the Appalachian Valley.

3. Geologic maps of type areas of formations in the Mascot-Jefferson City zinc district, Tennessee.

1. Index map of part of East Tennessee, showing location of Mascot-Jefferson City district.

2. Generalized columnar section for the Mascot-Jefferson City district . . . . . .

CharT 1. History of the stratigraphic terminology applied to the Knox group and associated Cambrian and $\mathrm{O}^{\text {-dovician }}$ In pocket formations in the southern Appalachians.

\section{TABLES}

TaBle 1. Distribution of species from the Chepultepec dolomite.

2. Distribution of species from the Longview dolomite and equivalent formations 


\title{
STRATIGRAPHY OF THE MASCOT-JEFFERSON CITY ZINC DISTRICT, TENNESSEE
}

\author{
By Jostah BRIDGe
}

\begin{abstract}
The Mascot-Jefferson City zinc district is underlain by Cambrian and Ordovician sedimentary rocks. Sulfide zinc deposits, the only ores now being exploited in the district, occur in limestone and dolomite layers of the Knox group. This group in East Tennessee has been divided, on the basis of work begun in this district but carried also into other areas, into five formations-in ascending order, the Copper Ridge dolomite, the Chepultepec dolomite, the Longview dolomite, the Kingsport limestone, and the Mascot dolomite. These units are distinguished and mapped by key beds of sandstone and limestone, by minor differences in type of dolomite, and especially by differences in the residuum overlying them. In the Mascot-Jefferson City district, the rocks have been deformed by large folds and thrust faults; the pattern of folding and faulting generally conforms to but is less regular than that in East Tennessee as a whole. The zinc deposits are found in the lower part of the Kingsport limestone (and locally in the top of the Longview dolomite) where the beds show brecciation or recrystallization or most commonly both, especially near the ends of minor thrust faults in the vicinity of anticlinal changes in strike.
\end{abstract}

\section{INTRODUCTION}

\section{By John Rodgers}

The Mascot-Jefferson City zinc district, one of the principal metal mining districts in the southeastern United States, is located in Knox and Jefferson Counties, Tenn., eastward from and within 25 miles of the city of Knoxville. Its location is shown in figure 1. The present report, which includes a geologic map (first published in 1945) of the zinc district and immediately surrounding area, emphasizes the stratigraphy of the district in relation to the stratigraphy of the whole southern Appalachian region; it is only secondarily concerned with the economic geology of the zinc deposits, which are described by Brokaw (1955). The manuscript for the present report was left unfinished at the death of its author in April 1953 and has been prepared for publication by John Rodgers, who has written the abstract and most of the introduction. Except for these, no sections were added to the report as Bridge left it, though several were expanded from other material that he left or in accordance with his instructions on the manuscript. As a result, some parts of the report are incomplete, notably the descriptions of some of the Ordovician formations. Incomplete as it is, however, the report summarizes the stratigraphy of the zinc-bearing rocks and of the Knox group in East Tennessee generally as no one but Bridge could have summarized it.

\section{SCOPE AND PURPOSE OF THE PRESENT REPCRT}

The present report is the result of a project of long standing, begun in 1929 as a pioneer attempt to subdivide stratigraphically the Knox dolomite of East Tennessee. For this attempt, the Mascot-Jefferson City zinc district was chosen for several reasons: the area includes a belt continuous with the type section of the Knox at Knoxville, information was desired on the unknown relation of the zinc deposits in the district to the surrounding geology, and a large-scale map of the vicinity of the Holston River within the ares, had recently been issued by the U. S. Army Engineers. Three general aims were set for the project: to test how far the Knox dolomite could be subdivided, to cetermine the stratigraphic and structural control, if any, of the zinc deposits, and to provide data for a possible revision of the State geologic map.

It was hoped from the beginning that this project would be only the first in a series of projects dirseted toward these aims; its success in achieving them in this area was indeed a major stimulus to the great amount of geologic work that has been carried out in East Tennessee in the last two decades. The original aims have now been almost completely achieved: the Knox dolomite is now a group divided into named formations in every part of East Tennessee and adjacent areas where detailed work has been done, the stratigraphic and structural control of the zinc deposits is fairly well understood (Brokaw, 1955), and a new geologic map of East Tennessee has been compiled and published (Rodgers, 1953). All these developments are outgrowths of Bridge's pioneering project.

Bridge was of course in close touch with all thesa new projects-which he aided enormously by his enthu- 


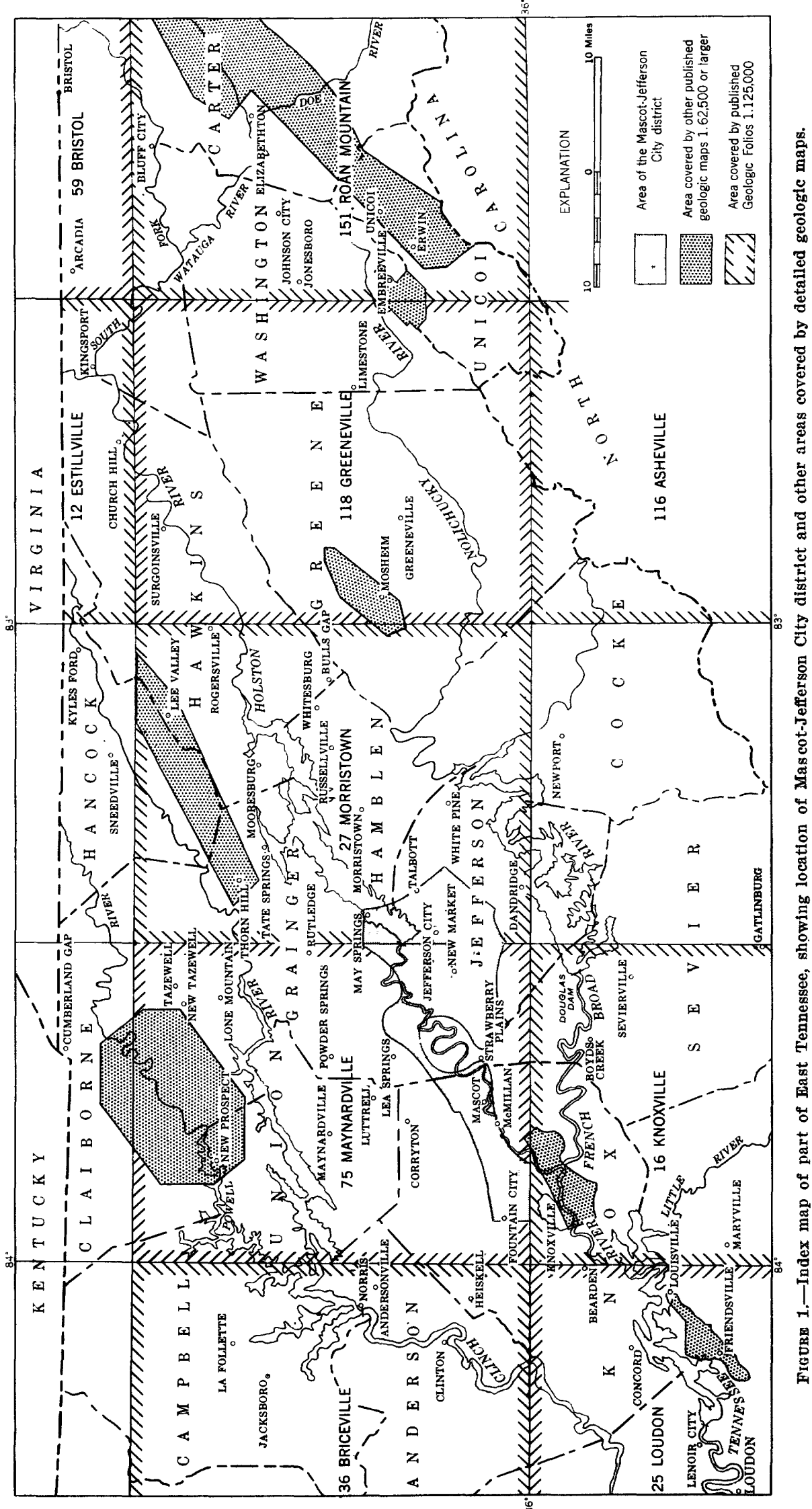


siastic encouragement and assistance-and, as they developed, his project also changed in scope. At his death, then, the aims of his report were to set forth the evidence on which his geologic map of the zinc district was based, to discuss the regional aspects of the geologic control of the zinc deposits, and, above all, to provide a definitive description of the subdivisions of the Knox to serve as a standard of comparison for other areas in the southern Appalachians.

\section{WORK BEFORE 19291}

In his pioneer work in Tennessee, Safford $(1869, \mathrm{p}$. 204) named the Knox group and divided it into three units which he termed the Knox sandstone, the Knox shale, and the Knox dolomite, respectively (chart 1). He placed these, together with the underlying Chilhowee sandstone and Ocoee series, in a large group which he termed the Potsdam, and he referred the Chilhowee sandstone to the Potsdam proper (that is, the Potsdam of New York). The limestones overlying the Knox dolomite, which was the youngest member of Safford's Potsdam group, were termed the Lebanon, Trenton, or Maclurea limestones. The name Knox was taken from Knoxville and Knox County (Safford, 1869, p. 204), and Safford's original section was measured along Second Creek in the city of Knoxville. This section lies just west of the area studied for the present report, partly in direct prolongation of the Mascot belt (p. 7 and pl. 2). Safford extended the term Knox dolomite to cover all the dolomitic limestones in this portion of the section in East Tennessee, and this classification was used with slight local modifications by various writers until about 1890 . Smith (1876 and later publications) used the term to include supposedly equivalent strata in northeastern Alabama.

Between 1890 and 1905, the U. S. Geological Survey mapped the greater portion of the southern Appalachian Valley in considerable detail and published a series of geologic folios covering most of eastern Tennessee and adjoining States. These folios were the work of several men, chiefly C. Willard Hayes, Marius R. Campbell, and Arthur Keith. In the folios, the Knox sandstone and shale were subdivided into a number of formations and Safford's terms were discarded. The name Knox dolomite was retained as a formation name with practically the same limits which Safford gave it, but the overlying Trenton, or Lebanon, limestone of Safford was called the Chickamauga limestone.

These men realized the composite nature of the Knox dolomite; in all their reports the Knox dolomite is

\footnotetext{
1 This section is taken with little change from one entitled "Previous work" In the preliminary report prepared by Bridge after his 1929 fleld season.
}

classed as Cambrian and Silurian ${ }^{2}$ or Cambrian and Ordovician in age. Moreover, they repeatedly stated that the base of the formation contained Cambrian fossils whereas the top contained Silurian (Calniferous) fossils and that it was impossible to drav any boundary between parts of the formation.

The most significant of these folios, for the present report, are the Knoxville folio (no. 16), the Morristown folio (no. 27), the Maynardville folio (no. 75), the Greeneville folio (no. 118), and the Roan Mountain folio (no. 151), all the work of Keith (fig. 1). The first of these folios covers the region immediately to the southwest of the area under discussion and contains Safford's original section. The second and third include the Mascot-Jefferson City area. In the other two, which embrace the area to the east and were published at a later date, there is a much more ext?nded discussion of the Knox dolomite, but still no at empt to subdivide it.

The first subdivision of the Knox was made by U1rich (1911, p. 633-640), who divided the Knox in the Knoxville area into three units: a lower unnamed limestone, the Copper Ridge chert, and an unnamed "Upper Division of the Knox." Ulrich stated the.t the sequence of units within the Knox is not the same in different parts of the Appalachian Valley. He also discussed many sections, proposed several new formations (including the Copper Ridge chert), and pointed out many of the unsolved problems of correlation.

For many years after this, Butts worked on problems of Appalachian stratigraphy. With the cooperation of Ulrich, he subdivided the Knox in Als.bama and Virginia (also later Georgia) into several units, and his results appeared on the geologic maps of those States. Before 1929, however, no attempt was made to map the areal distribution of these units in Tenrossee.

Purdue (1912) and Secrist (1924) described th ninc deposits of the district, but neither of them attempted a subdivision of the Knox, although Secrist published a correlation table for East Tennessee compiled by Nelson from data supplied by Ulrich.

\section{RECENT WORK IN THE KNOX GROUP OF EAST TENNESSEE}

In 1929, Captain Walter F. Pond, the State Geologist of Tennessee, employed Bridge, who was then teaching at the Missouri School of Mines and had recently completed mapping two 15-minute quadrengles in the Ozarks in formations equivalent to the Knox group, to undertake the project of subdividing the Knox in East Tennessee. In April, Bridge and Pond,

a The Ordovician period had not been recognized by the U. S. Geilogical Survey at the time the earlier folios were published. 
representing the Tennessee Division of Geology, took part in a field conference with Ulrich and Butts, of the U. S. Geological Survey, making a reconnaissance trip from Bristol to Knoxville by way of Bluff City, Johnson City, Greeneville, and Morristown. During this trip Ulrich and Butts gave Bridge the benefit of their knowledge of the sequence of units then recognized in the Knox group of the southern Appalachians, pointed out the criteria used for separating these units, and especially introduced him to the two principal standard sections of the Knox in East Tennessee-the section along Jockey Creek near Limestone in Washington and Greene Counties and the section along Forked Deer Creek near Thorn Hill in Grainger County. Following this field conference, Bridge spent the summer mapping the Mascot-Jefferson City zinc district on the maps available: the Holston River Survey of the U. S. Army Engineers, a map of the area between New Market and Jefferson City, compiled and kindly loaned by the Universal Exploration Co. (now part of the Tennessee Coal \& Iron Division of the U. S. Steel Corp.), and planetable traverses made especially for the project by W. B. Brewer and T. G. Andrews, of the U. S. Geological Survey. During the school year 1929-30, Bridge prepared a report of about 85 typescript pages which he transmitted to the Tennessee Division of Geology in 1930.

In 1930, Bridge became a member of the U. S. Geological Survey, and Pond employed C. R. L. Oder to carry forward the Tennessee Division of Geology project on the subdivision of the Knox group. From 1930 until 1934, when he became geologist with the American Zinc Co. of Tennessee, Oder worked on this project, mapping subdivisions of the Knox in several parts of East Tennessee, notably in the Morristown-Russellville area northeast of the Mascot-Jefferson City district. In 1934, he published a preliminary paper on the results of this work (Oder, 1934). More recently he has carried forward his detailed mapping in the MorristownRussellville area, but his report on this area has not appeared.

In 1932 and 1933, the late Professor George M. Hall and Professor H. C. Amick, of the University of Tennessee, made a detailed bed-by-bed measurement of the Thorn Hill section. This very useful document was published in 1934.

In 1934, the U. S. Geological Survey began a project to investigate the zinc deposits of southwest Virginia and East Tenmessee, under the direction of D. F. Hewett and L. W. Currier. Considerable material was assembled and some short articles were published, but no final report on the Tennessee phase of the project was completed. Shortly thereafter the Geologic Division of the Tennessee Valley Authority was or since then it has carried on a great deal of geologic work in East Tennessee. In the first years of the Division, a reconnaissance survey of the Nor is Reservoir area was made by James S. Cullison and others, who used some of the subdivisions of the Knox group already established by Bridge. The report on this survey has not been published. Several short papars on other projects have appeared, and a more general report on the work of the Division has been published by the Authority (Moneymaker, Leonard, and others, 1949).

In 1937, the Tennessee Valley Authority began the publication of large-scale planimetric maps of East Tennessee. As a joint project of the Tennessee Division of Geology and the U. S. Geological Survey, Bridge spent several months in 1937, 1938, and 1939 remapping the area on the new base and began a revision of the 1930 report. At this time, Oder and Bridge agreed upon a terminology for the subdivisions of the Knox group for their two reports; this terminology has been accepted and used in all more recent work in East Tennessee. Bridge's revision was interrupted, however, for strategic minerals defense projects in 1941, and neither he nor Oder was able to prepare a definitive publication of the new terminology.

In 1942, the U. S. Geological Survey, as a part of its strategic minerals program, continued its investigations of the zinc deposits of East Tennessee, loading to the publication beginning in 1943 of several preliminary maps and reports, depending for their stratigraphy on Bridge's unpublished report and makirg use of its terminology. The final report on this projact is in preparation by Brokaw. As a phase of this prcject, Bridge's data were transferred to the new topographic maps published jointly by the Tennessee Valloy Authority and the U. S. Geological Survey, and the map was published without text in $\mathbf{1 9 4 5}$ by the Tennessee Division of Geology.

Since 1945, much geologic work has been done in East Tennessee, and most of it through 1950 was incorporated into a new geologic map of East Tennessee compiled by Rodgers and published by the Tennessee Division of Geology in 1952. Again the terminology of the Knox group was taken from the unpublished reports by Bridge and Oder; a fairly detailed though not definitive discussion of this terminclogy was included in the text accompanying the mp (Rodgers, 1953).

In 1947 and again in 1950, Bridge and Rodgers reviewed the Mascot-Jefferson City report in order to begin a final revision, and from 1950 until his death in April 1953, Bridge carried forward his work on the report along with work on other commitnents. At the 
time of his death, he had completed in semifinal form the descriptions of the rock formations through the Chepultepec dolomite and the sections entitled "Structure" and "Economic generalizations" and had prepared less final and less complete material for all other parts of the report except the introduction. This material constitutes the present report.

\section{THE GEOLOGIC MAP AND MAPPING PROCEDURES}

Bridge intended to prepare a section for the introduction entitled "Accuracy of the map," in which he wished particularly to emphasize how the contacts between the formations of the Knox group were drawn and how uncertain they may be locally. Although the pre-Knox and post-Knox formations crop out fairly extensively in most areas where they occur, the rocks of the Knox group are mostly covered with a thick mantle of cherty residual clay. Scattered outcrops occur, and the map indicates nearly all by dip and strike symbols. Except where the outcrops form nearly continuous sections, however, they are of little direct help, for the various kinds of dolomite are repeated through most of the group and isolated outcrops are rarely critical. In most of the area, therefore, the contacts are based on evidence from residuum: on fossils in the chert if they can be found, on differences in the kinds of chert, or on other residual materials like sandstone. In a broad way, a first division of the Knox group in this area is made by finding the band of sandstone residuum from the zone of sandstone layers that straddles the boundary between the Copper Ridge and Chepultepec dolomites. On the stratigraphically lower side of this band, the sandstone blocks are commonly mixed with blocks of coarsely oolitic chert; there are also other differences in the chert on the two sides. This band, or more exactly the stratigraphically higher edge of the part with oolitic chert blocks, is assumed to indicate the CambrianOrdovician boundary. The part of the Knox group below this boundary, the Copper Ridge dolomite, is not further divided, except locally by special criteria, but the base of the group may also be mapped on the basis of residuum, for it is marked by the abrupt lower limit of abundant chert.

The Ordovician part of the Knox group can generally be further divided into three parts by a band in which the residuum is exceptionally cherty-the chert being normally in large massive light-colored blocks and containing molds of the gastropod Lecanospira-and over which the hills are generally somewhat higher than on either side. On the stratigraphically higher side of this band, limestone (or recrystallized dolomite, see p. 47, 54) is commonly found if outcrops are present. This band is mapped as the Longview dolomite (which includes several thinner limestone beds but excludes at the top a thick and fairly distinctive bed that can be found wherever exposures are sufficient), and the band bitween it and the contact in the sandstone band is mapped as the Chepultepec dolomite. The band stratigraphically above the Longview is further divided into the Kingsport limestone below and the Mascot dolomite above by finding residual float or outcrops of a characteristic sandstone with a chert matrix, which forms a valuable key bed in this part of East Tennessee.

But residual materials, such as chert or sardstone blocks, are very apt to creep downhill or to settle vertically far below the level at which they were originally released from the bedrock, and either process could introduce serious systematic errors into the mepping. Bridge was well aware of this difficulty, and, as far as possible, he checked the residuum against all available outcrops and against the projected dip and st:ike of any known contacts. Moreover, it should be mentioned that at no time during the mapping did Bridge have access to any underground information, except for a few scattered drill records. Despite these diffirulties, Bridge's mapping has proved in fact to be rmmarkably accurate, when checked by later drilling and underground development, and he often took considerable pride in these verifications, as, for example, his prediction of not only the surface trace but the subsurface position of the Rocky Valley fault under Koppick Knob south of Jefferson City.

\section{ACKNOWLEDGMENTS}

In a letter dated 1947 , Bridge states that "acknowledgments will of necessity be many," but unfortinnately he was unable to prepare the list. The one below, therefore, reconstructed by Rodgers after Bridge's death, runs the risk of injustices, both of omission and of misplaced emphasis.

Acknowledgments for assistance during the life of the project and in the preparation of the manuscript are due to Walter F. Pond, who originally proposed the project; H. A. Buehler, who suggested E ridge's assignment to it on the basis of his successful rork in Missouri; E. O. Ulrich, Charles Butts, August F. Foerste, and the others who helped train him in the paleontology and stratigraphy of the Knox group and its equivalents; the geologists in charge of the various field parties in the southern Appalachians with whom he collaborated-D. F. Hewett, L. W. Currier, E. C. Eckel, and C. H. Behre, Jr.; the zinc companies in the area-the American Zinc Co. of Tennessee, and the Universal Exploration Co., now part of the Tennessee Coal \& Iron Division of the U. S. Steel Corp.--and their officials and geologists-Hiram Mills, Mark H. 
Newman, Charles R. L. Oder, H. A. Coy, Floyd Weed, and Johnson Craw ford; and many other geologists, including George M. Hall, H. C. Amick, and R. E. Lee Collins; Robert A. Laurence, Benjamin Gildersleeve, Berlen C. Moneymaker, C. B. MacGavock, James S. Cullison, John C. Dunlap, and C. H. Prouty, Jr.; Mrs. Christina Lochman Balk, A. R. Palmer, and Arnold L. Brokaw, for their help at various stages in the project.

\section{GEOGRAPHY}

The Mascot-Jefferson City area lies in the Valley of East Tennessee, a part of the Appalachian Valley and Ridge province. The Valley extends entirely across Tennessee from Bristol to Chattanooga between the Unaka and Great Smoky Mountains along the North Carolina State line on the southeast and the Cumberland Plateau on the northwest. The Mascot-Jefferson City area lies about halfway from Bristol to Chattanooga, almost in the center of the Valley, here about 50 miles wide.

This part of the Valley of East Tennessee is chiefly rolling country, marked by several broad ridges trending northeast. The ridges crossing the area mapped are less regularly distributed than in most parts of the Valley. The most prominent is Shields Ridge (called Bays Mountain on the 1945 map, Bridge, $1945^{3}$ ), which reaches an altitude of about 1,750 feet above sea level. Narrower, sharper ridges with the same northeast trend extend along the northwest and southeast edges of the mapped area. Just to the north and northeast are House and Clinch Mountains, the southwesternmost of the prominent linear mountains that characterize the northwest part of the Valley and Ridge province in northeast Tennessee and Virginia. The total relief in the mapped area is about 900 feet, but House and Clinch Mountains add another 500 feet. The local relief rarely exceeds 600 feet. (See pl. 1.)

The Holston River winds westward across the center of the area, and just south of the southwest corner it joins the French Broad River to form the Tennessee.

\footnotetext{
The name Bays Mountain, or Bays Mountains, is indiscriminately applied to a series of disconnected ridges between Kingsport and Maryville, Tenn. The principal ridge and the one most universally known as Bays Mountain is the synclinal mountain group starting just southwest of Kingsport and extending southwestward past Bulls Gap to the Nolichucky River about 7 miles southeast of Morristown. The name is also applied to a series of three or four subparallel monoclinal ridges starting in the vicinity of Whitesburg, extending southwestward along the valley of Dumplin Creek, crossing the French Broad River, and finally dying out in the vicinity of Rockford north of Maryville. These ridges are not a continuation of the first one mentioned but are about 3 mile northwest of and in echelon to it. Still a third ridge, sometimes known as Bays Mountain, is the short, steep ridge forming the south wall of Rocky Valley within the New Market and Jefferson City quadrangles. This ridge lies 2 or 3 miles northwest of the second group described above and is entirely distinct from them. It is also known locally as Shields Ridge. That name appears on the new Jefferson City quadrangle map and will be used in this report.
}

North of Jefferson City, the Holston is ponded by Cherokee Dam to form Cherokee Reservoir, which covers several square miles in the northeast corner of the area and extends many miles farther eastward. Most of the mapped area drains into the Jolston, but south of Shields Ridge the streams flow generally southward to Dumplin Creek, a tributary of the French Broad. Important tributaries of the Holston within the area are, on the north side, Buffalo, Richland, Big Flat, and Roseberry Creeks, and, on the south side, Mossy, Lost, and Beaver Creeks. One of the striking hydrographic features of the region is the prominence of underground drainage; thus Lost Creek goes underground about a mile from the Holston River and perhaps 40 feet above it, and its waters apparently reappear in a large spring on the east bank of the river opposite McBee Island. Many smaller stre ms likewise disappear into sinks, and an area of several square miles east of Jefferson City, extending nearly to Morristown, 14 miles north-northeastward, is entirely without ordinary surface drainage but is pocked with innumerable sinks, large and small.

A very large proportion of the area is cleared, much of it for cultivation of tobacco, corn, and small grains, much of it for pasture. Woodland is sparse on low ground, commoner in hilly areas, and widest spread on the steeper slopes of the more prominent ridges, such as Shields Ridge. The principal towr 9 in the area are Jefferson City (1950 population, 3,633), New Market (600), Strawberry Plains (400), and Mascot $(1,800)$; the city of Knoxville $(124,769)$ lies at the southwest corner of the area. Mascot-a companyowned town-Jefferson City, and New Market are the main seats of the zinc mining industry, though Jefferson City has also several mills or shore and is the seat of Carson-Newman College (1950 enrollment, 895). A main line of the Southern Railway (here doubletracked) crosses the center of the area from east to west, connecting Washington, D. C., and Bristol, Va.Tenn., with Chattanooga, Tenn., Memphis Tenn., and Birmingham, Ala.; and Charleston, S. C., and Asheville, N. C., with Cincinnati, Ohio, and Lrisville, Ky. The railway maintains a large freight classification yard at John Sevier, near the west end of the area. U. S. Highway 11-E roughly parallels the railway across the area, U. S. Highway $11-W$ crosses the northwest part of the area, and U. S. Highwars $25-W$ and 70 (here following the same route) skirt the southern edge; the highways and the railroad converge at Knoxville at the southwest corner of the area. State Highway 92 passes north and south through Jefferson City, connecting it with U. S. Highway $11-\mathrm{W}$ at Rutledge and U. S. Highway 70 at Dandridge, both a little be- 
yond the limits of the map. U. S. Highway 25-E passes north and south through Morristown, about 10 miles to the east of the area.

A network of county roads, some paved, the others mostly macadamized, gives ready access to all parts of the area. The Holston River forms the most significant barrier to movement, and it is bridged at three points: just north of Jefferson City (State Highway 92), between Strawberry Plains and Mascot, and south of John Sevier (U. S. Highways 11-E, 25-W and 70).

\section{STRATIGRAPHY}

The rocks of the Appalachian Valley are almost entirely of sedimentary origin and consist of conglomerates, sandstones, shales, limestones, and dolomites. They range in age from Early Cambrian to Carboniferous. In the Mascot-Jefferson City district limestones and dolomites are by far the most abundant lithologic types, and no consolidated rocks younger than Middle Ordovician are present.

The stratigraphic column for the district is shown on chart 1 and in the columnar section, figure 2.

The Mascot-Jefferson City district may be divided into three distinct narrow subparallel structural belts, which strike approximately northeast, and which are separated from one another by thrust faults (pl. 2). Each belt is a portion of a great fault block which has been thrust over a part of the block lying to the northwest of it, and in each block the sequence of formations is repeated. In this report the following names will be used for these major thrust faults and belts, beginning at the northwest: Saltville thrust fault, ${ }^{4}$ Mascot belt, Mill Spring thrust fault, Jefferson City belt, Rocky Valley thrust fault, ${ }^{4}$ Shields Ridge belt, and Dumplin Valley thrust fault.

\section{PRE-KNOX FORMATIONS \\ SUMMARY DESCRIPTION \\ NAMES AND DISTRIBUTION}

The pre-Knox formations range from Early to Late Cambrian in age and consist of five easily differentiated formations. These, in ascending order, are the Rome formation (Lower Cambrian), the Rutledge limestone, Rogersville shale, and Maryville limestone (Middle Cambrian), and the Nolichucky shale (Upper Cambrian). The Rogersville shale is further divided into a lower and upper shale member separated by the Craig

4 On the geologic map issued in 1945 (Bridge, 1945), the Saltville fault was called the Richland fault, but the name Saltville is older and has been widely used for this fault. Likewise, the Rocky Valley fault was called the Bays Mountain fault, but that name had previously been used by Gordon (1918, p. 54) for an entirely different fault south of Knoxville, and it is therefore abandoned in this report. For a discussion of the various Bays Mountains of East Tennessee, see Safford (1869, p. 43) and the footnote on page 6 of this report.

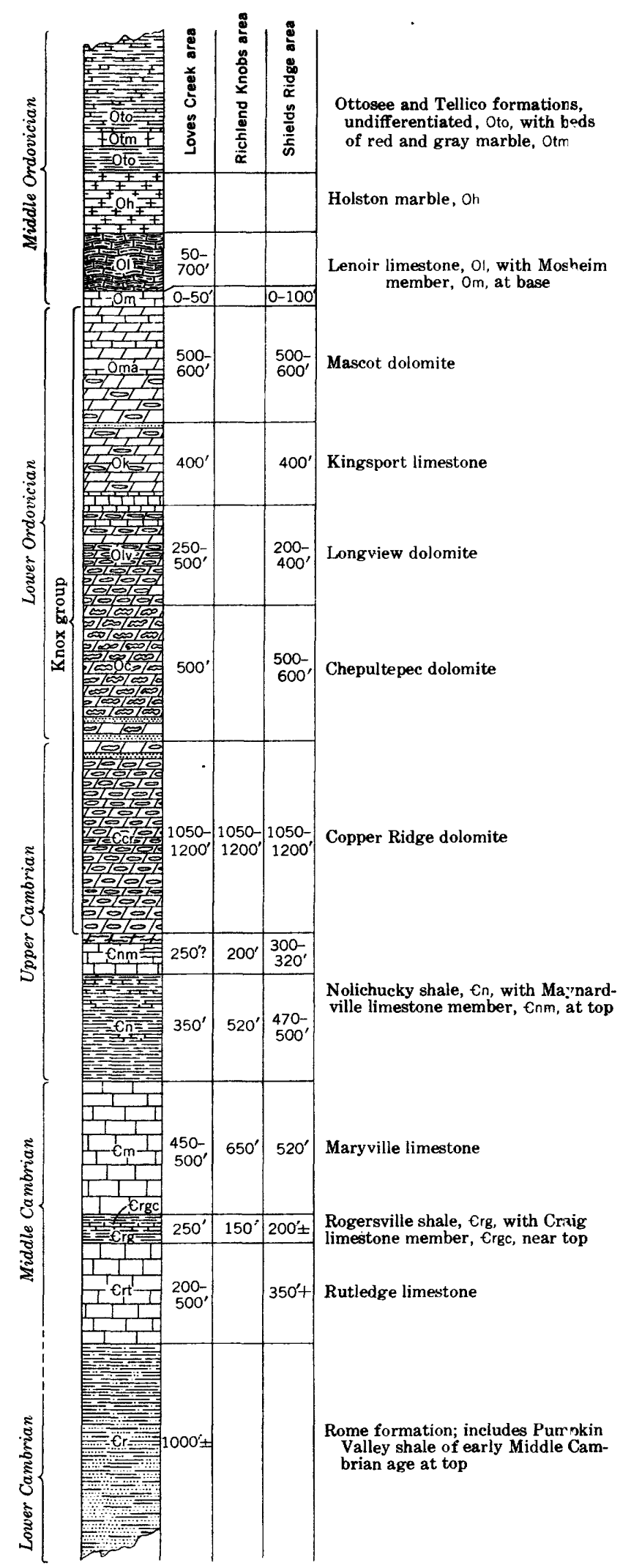

Figure 2.-Generalized columnar section for the Mascot-Jefferson City district. 
limestone member; the Nolichucky shale is divided into a lower shale member and an upper limestone and shale member, the Maynardville limestone member. All five formations were named and described in the early Appalachian Valley folios, and their distribution was well shown on the accompanying maps. More recently, their faunas have been figured and described (Resser, 1938). All five formations crop out within the mapped area; but, inasmuch as they have been well described in other reports, do not carry any of the zinc deposits in the area, and, with the exception of the Maynardville limestone member of the Nolichucky shale, are not connected with the problem of subdividing the Knox group-the original aim of this report (see p. 1) -only a generalized description will be given. They have been mapped throughout the Mascot-Jefferson City area partly for the sake of completeness but mostly because of their importance in interpreting structure.

\section{ROME FORMATION}

The Rome formation, named by Hayes (1891, p. 143146) from exposures in the city of Rome, Ga., forms the base of the section in the Mascot-Jefferson City district. Along the eastern edge of the Appalachian Valley, where complete sections of the formation are exposed, the Rome formation rests upon the Shady dolomite, also of Early Cambrian age. Throughout the central and western portions of the Valley, however, it is the oldest formation exposed in any section and either occupies the center of an anticline or is cut off below by a thrust fault. In the Mascot-Jefferson City district the Rome formation averages about 1,000 feet in thickness and consists largely of thick rusty sandstones below and of arenaceous varicolored shales above. Yellow, orange, and maroon tones are prominent in the shale, but the highest beds are mostly greenish; these greenish beds appear to correspond to the Pumpkin Valley shale as described by Rodgers and Kent (1948, p. 7-9) at Lee Valley, Hawkins County, Tenn. Thin beds and lenses of limestone and dolomite, some of which are fossiliferous, occur locally in the Rome formation.

Within the district the Rome formation crops out in three areas: in Legg, Rogers, and McAnnally Ridges along the northwestern edge of the Mascot belt in the John Sevier quadrangle; in the center of the Rocky Valley anticline in the New Market quadrangle; and in the high unnamed ridge between Piedmont in the New Market quadrangle and Oakland in the Jefferson City quadrangle along the southeastern border of the area. The material in the crest of the Rocky Valley anticline would now be classed as Pumpkin Valley shale; the other areas contain strata belonging to the underlying part of the Rome formation as well. Good exposures may be found in the gap north of Bethlehem Church (John Sevier quadrangle) and along State Highway 92 in the gap southeast of Flat Grp (Jefferson City quadrangle).

\section{RUTLEDGE LIMESTONE}

The remaining four formations were named by Keith for exposures in the Maynardville, Morristown, Knoxville, and Greeneville quadrangles, respect:vely (Keith, $1901,1896,1895,1905)$, but the first description of all four was given by Campbell $(1894$, p. 2). The descriptions of the formations in their type areas followed at intervals over a period of several years.

The Rutledge limestone was named for exposures "in the valley of Rutledge, Grainger Co'nty," Tenn. (Keith, 1901, p. 2). No type section has ever been designated, but there are good exposures of the formation in the valley of the unnamed tributary of Richland Creek about 1 mile, west of Rutledge (Dutch Valley quadrangle), and with further study a type section might be established here. Good exposures have also been made nearby along the new location of U.S. Highway 11-W west of Rutledge. Most of the formation is massive dark-blue to black limestone exhibiting banding, especially on weathered surfaces, and closely resembling much of the limestone in the overlying Cambrian formations, but according to Keith the lower part of the formation includes shale bed and grades imperceptibly into the underlying shales of the Rome formation. Resser (1938, p. 11), on the basis of Middle Cambrian fossils in these shales, considered them to be part of the Rutledge. Actually they were originally included in the Rome formation, and they are now placed in the Pumpkin Valley shale of Rodgers and Kent (1948).

Within the Mascot-Jefferson City area the Rutledge limestone is exposed near the northwest edge of the Mascot belt in the John Sevier quadrangle and in Rocky Valley in the Shields Ridge belt in the Ner Market and Jefferson City quadrangles. The limestores are highly soluble, and good exposures are rare; the best are in Rocky Valley about 3 miles south of New Market.

The Rutledge limestone is about 500 feet thick in the type area near Rutledge, but the limestone beds are replaced by shales toward the southwest. In the section along Loves Creek near the westerr edge of the Mascot belt (John Sevier quadrangle) the formation is difficult to recognize, for it is compos?d largely of shale.

\section{ROGERSVILLE SHALE}

The Rogersville shale was named from exposures near Rogersville, Tenn. (Keith, 1896, p. 2), but the 
exact type locality was never specified. It is a gray argillaceous shale that weathers to a fairly distinctive light-greenish color (5 GY 6/1, light greenish gray, to $10 \mathrm{Y} 6 / 2$, pale olive, according to color measurement by Robert A. Laurence, personal communication, 1953). It is remarkably persistent in this part of the Appalachian Valley in East Tennessee and, because of its color and persistence, is an excellent key bed. In the Mascot-Jefferson City district and in much of the surrounding region the shale is divided into upper and lower members by a thick bed of limestone, here termed the Craig limestone member (name first used by Rodgers and Kent, 1948, p. 10). The name is taken from the Craig quarry (pl. $3 C$ ) in the southern edge of the village of Rutledge, where the entire member is well exposed.

Type section of the Craig limestone member of the Rogersville shale, measured in the quarry 0.14 mile south of the junction of $U$. \$. 11-W and Tennessee 92 at Rutledge, Tenn., in bluff south of Richland Oreek and just east of sharp turn in Highway 92 (pl. $3 \mathrm{C}$ )

[Measured by Josiah Bridge, 1940]

Maryville limestone: Base, exposed in field about $100 \mathrm{ft}$ south of the quarry.

Rogersville shale:

Upper shale member: Exposed on flat at top of bluff. Shale, light-green, well-bedded, soft, calcareous, weathering to small, splintery chips. Strike N. $70^{\circ}$ E., dip $20^{\circ} \mathrm{S}$. Calculated thickness.

Craig limestone member :

13. Limestone, rather poorly exposed on flat south of the quarry, similar to the main mass described below. Calculated thickness

12. Limestone, dark-blue, flnely crystalline to aphanitic; massively bedded with irregular, wavy partings of black glistening carbonaceous material, also with irregular mottlings of gray finely crystalline dolomitic material, which weather into low relief and resemble fucoidal markings, especially when seen on bedding planes_-

11. Dolomite, gray, crystalline; weathers to a sugary surface.

10. Limestone, similar to bed 12_.....-

9. Limestone, similar to bed 12

8. Limestone, similar to bed 12 ; dolomitic portions weathered into high relief and closely resembling fucoids -_-_-_-

7. Limestone, similar to bed 12

6. Limestone, similar to bed 12

5. Limestone, similar to bed 12

4. Limestone, similar to bed 12 , forms the floor of the upper half of the quarry. Strike N. $70^{\circ}$ E., dip $25^{\circ}$ SE
Rogersville shale-Continued

Craig limestone member-Continued

3. Limestone, similar to bed $\mathbf{1 2}$

2. Limestone, similar to bed 12

1. Limestone, similar to bed 12 ; top of this bed is the floor of the lower half

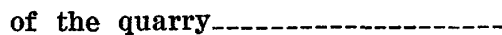

Total Craig member

\begin{tabular}{rr}
1 & 0 \\
\hline 83 & 0
\end{tabular}

Lower shale member: Poorly exposed below quarry but contact well shown in roạd cuts 100 yd west. About 30 ft exposed to creek.

The limestone of the Craig member was quarried for dimension stone and interior trim. It takes a high polish and is said to furnish a superior grade of black marble, though somewhat mottled. In the section above, the units are purely arbitrary and were selected with reference to the prominent bedding planes at this locality. Except for the nonpersistent bed of $\mathrm{do}^{\top}$ omite (unit 11), the limestones are remarkably uniform from top to bottom; such differences as appear to exist are merely due to differences in the amount of weatjlering of the particular surface studied.

The Craig limestone member is indistinguirhable lithologically from the Rutledge limestone beneath and the Maryville limestone and some of the limestone in the Maynardville limestone member above, but, occurring as it does between two bands of light-green shale, it is an extremely valuable key bed.

The Rogersville shale crops out in the Mascct, belt across the John Sevier, Mascot, and Luttrell quedrangles; it is well exposed in the center of the Rockr Valley anticline in the New Market and Jeffersor City quadrangles. Formerly there were poor exposures of the shale in the center of the Cherokee anticline east of Cherokee Dam in the Talbott quadrangle, but these were submerged by the filling of Cherokee Lake.

The Rogersville shale (including the Craig limestone member) reaches a maximum thickness of 250 feet in this area, but northeastward and southeastward it thins

\section{0}

0

6
0

6

0

0

0
and finally is completely replaced by limestone. To the southwest it becomes indistinguishable because of the replacement of the overlying and underlying limestones by shale, and it has not been recognized as a mappable unit much west of the longitude of Maryville, Plount County (see p. 18). The Craig limestone member is 86 feet thick in the type section and thins to the south and southwest, but it is present in all exposures of the Rogersville in the Mascot-Jefferson City district. It is about 50 feet thick in Rocky Valley where it commonly has a thin band of shale near the top. It comprises units 63 to 70, inclusive, of the Thorn Hill section (Hall and Amick, 1934) where it has a thickness of 36 feet, 
11 inches, ${ }^{5}$ and it forms unit 52 (47 feet thick) of the Lee Valley section (Rodgers and Kent, 1948, p. 11).

The shales of the Rogersville are quite fossiliferous, and the fauna from them has been described and figured by Resser (1938).

\section{MARYVILLE LIMESTONE}

The Maryville limestone was named for exposures near Maryville, Tenn. (Keith, 1895, p. 3). The exact location of the type area was not stated, but it is presumably in the belt of Cambrian rocks cropping out northwest of the town. This belt extends northeastward and occupies the valley of Dumplin Creek south of Jefferson City and just south of the area mapped. The Maryville limestone is composed of massive darkblue or bluish-black limestones, similar to the Rutledge limestone and the Craig limestone member of the Rogersville shale below and also to some phases of the Maynardville limestone member of the Nolichucky shale above. The formation is between 300 and 400 feet thick in the type area and apparently reaches a maximum of between 600 and 700 feet on the Richland Knobs escarpment south of Rutledge. Like the Rutledge, its limestones thin out rapidly to the southwest, and in the section along Loves Creek at the western end of the area it is largely replaced by shale. It has not been mapped as a distinct unit more than a short distance southwest of Madisonville, Monroe County.

The Maryville limestone crops out near the northern edge of the Mascot belt, in the John Sevier quadrangle, and also in Rocky Valley in the New Market and Jefferson City quadrangles. As with the Rogersville, there were once exposures of this formation in the center of the Cherokee anticline as shown on the Joppa and Talbott quadrangles, but these are now almost entirely submerged except at low stages of Cherokee Lake. There are good exposures in the abandoned quarry on the old route of U. S. Highway 11-W where it crosses Big Flat Creek at Brice Bridge (Mascot quadrangle), on State Highway 92 south of Rutledge, and on the road on the north face of Shields Ridge 3 miles south of Jefferson City.

For many years the Maryville limestone had been considered to be unfossiliferous, and its stratigraphic age was inferred from its position between the fossiliferous Rogersville and Nolichucky shales. Walcott (1916, p. 391-392, 396-401, 404) described species of Asaphiscus, Blountia, Maryvillia, and Lisania (?) from limestones classed as Maryville limestone at several localities, and on the basis of these placed the Mary-

\footnotetext{
5 few errors in addition in the section of Hall and Amick have been corrected in the thicknesses from the Thorn Hill section given in this report. See Rodgers and Kent, 1948 , p. 3.
}

ville limestone in East Tennessee in the Tpper Cambrian, but these fossils are now known to have come from the Maynardville limestone member of the Nolichucky shale (Resser 1938, p. 12, 15;1942, p. 3). About 1935 or 1936, fossils were found in a thin shale layer, unit 103 of the Thorn Hill section. The fauna from this layer was described and figured by Fesser (1938, p. $27,74,94,48)$ and consists of the following: Deltophthalmus halli Resser, Proagnostus maryvillensis Resser, Perioura masoni Resser, and Obolus sp. Resser (1938, p. 13) also mentions the occurrencs of oboloid brachiopods in a thin shale on U. S. Highway 25-E "a little more than 6 miles north of M"orristown." Later, Resser (1942) listed a number of faunas from the "Maryville formation" at various localities in Tennessee, Alabama, and Georgia. He was using the term "formation" in a faunal rather than a lithologic sense, and in most of the localities listed the fcrmation has either lost or nearly lost its distinctive litr ologic character and has been replaced by shale. All the faunas listed by him have been found either in shale or in limestone nodules in shale commonly mapped as Conasauga.

In 1943, P. E. Cloud, Jr., found a single trilobite in limestone at the base of unit 124, in the Thorn Hill section, and this was identified by N. M. Denson as Alokistocare cf. A. georgense Resser, a typical Middle Cambrian form (personal communication to Cloud, 1943). The specimen came from a bed $2 ?$ feet below the Nolichucky contact and was the first known occurrence of fossils in limestone in the formation in Tennessee; the present statement is probably the first published notice of the find. According to Denson, this fossil indicates a horizon very near the top of the Middle Cambrian in the Cordilleran trough, and its presence in the Appalachian Valley lends strong support to the current practice of drawing the top of the Middle Cambrian at the top of the Maryville limestone in East Tennessee. Early in 1953, the writer and $\mathcal{A}$. R. Palmer found additional fossils in the Maryville limestone that confirm this age assignment.

\section{NOLICHUCKY SHALE}

The Nolichucky shale was named by J'eith (1905, p. 5) from exposures along the Nolichucky River in the Greeneville region, but the name was first used by Campbell $(1894$, p. 2$)$ for strata in the Estillville quadrangle, which he correlated with those afterward described by Keith. No type section was designated, but the type area is certainly the long, narrow anticline crossed and recrossed by the Nolichucky River a few miles southeast of Greeneville. This is in the area cov- 
ered by the Greeneville folio, not by the Morristown folio as stated by Wilmarth (1938, p. 1505).

The bulk of the Nolichucky consists of soft wellbedded yellowish to olive-green calcareous shale. The slightly darker and browner color of the weathered shale (5 Y 5/2, light olive green, to 10 YR 5/4, moderate yellowish brown, according to color measurements by Robert A. Laurence, personal communication, 1953) and the much greater thickness of the unit serve to distinguish it from the Rogersville shale. Locally, some of the shales near the base are maroon and in this respect resemble the thick shales of the Rome formation. Thin beds of limestone from a fraction of an inch to a few inches thick commonly occur at irregular intervals throughout the formation-another distinction from the Rogersville shale. Some of these limestones are fine grained, others coarser. Beds of edgewise conglomerate as much as 18 inches thick occur at various levels, but the number of these beds varies from place to place and some sections reveal none. Toward the top of the formation the limestone beds become much thicker and much more abundant; therefore in this report this limestone unit is separated from the lower shale unit as the Maynardville limestone member. Because these beds have been included in the Knox group by some authors, the Maynardville member is more fully discussed in this report than the formations underlying it.

\section{MAYNARDVILIE LIMESTONE MEMBFR OF NOLICHUCKY} SHALE

Keith and other early workers noted the thick limestone beds in the upper part of the Nolichucky shale. Where these beds were separated from the overlying Knox by a distinct bed of shale they were considered to be a portion of the Nolichucky, but, where the shale bed was missing, the uppermost limestones, especially the fine-grained magnesian varieties, were included in the Knox.

Ulrich recognized these beds as a stratigraphic unit and, in his first subdivision of the Knox dolomite, called it the "Basal division of the Knox dolomite (s. st.)" and described it as "grayish dolomite and limestone, practically free of chert" (Ulrich, 1911, p. 635). He noted that it "varies considerably in thickness, possibly being absent altogether locally," and stated that it had been recognized at Knoxville and therefore was a part of the original Knox dolomite of Safford. He did not discuss the contact with the Nolichucky, although elsewhere in the same paper he states that "gradual transition is suggested either by increasing development of limestone upward in the Nolichucky or by interbedding of thin layers of shale with relatively pure and more highly magnesian limestone in the basal part of the Knox" (Ulrich, 1911, p. 627). At the same time he carefully excluded all strata carrying identifiable Nolichucky fossils from his "Basal division." Despite the evidence cited above, he believed the contact bitween this basal division of the Knox and the Nolichucky to be unconformable and placed the "Six Mile series" of Alabama in this hiatus (see p. 26).

In 1933, in fieldwork around Norris Dam for the Tennessee Valley Authority, Arthur Keith recconized two mappable units-the limestone and the chert-free dolomite-between the shale of the Nolichucky and the cherty dolomites of the Knox group, but the results of this work have not been published.

The name Maynardville was proposed by Oder (1934, p. 475-476) for essentially the same limestones that were included in Ulrich's "Basal division of the Knox." Like Ulrich, he regarded it as a distinct formation and considered it the basal unit of the Knox group, al though he realized that the rocks contained in it had at times been considered wholly or in part a portion of tha Nolichucky. Oder's type section (unpublished) was measured along old Tennessee State Highway 33, at the mouth of Fall Creek on the northwest slope of Chestnut Ridge, $51 / 2$ miles north of Maynardville and just southwest of Ousley Bridge (Oder, 1934, p. 475; Keith, 1901, map). Inasmuch as this section is now covered by Norris Lake and is no longer accessible ever at extreme low lake stages, a new section has been salected on the present State Highway 33, at a point 7 miles northeast of Maynardville between the bridge crossing Cox Branch and the south end of the Clincl River bridge crossing Norris Lake (pl. $3 B$ ). This is in the vicinity of Needham Ford on the Maynardville folio map. The old and new sections are only abcrit $31 / 2$ miles apart and are located on the same belt of ortcrop, so that the transferring of the type section to tl is new locality does not raise any serious question of miscorrelation.

Oder's original locality is well shown on the new $71 / 2^{\prime}$ Maynardville quadrangle and the new locality is shown on the adjoining Powder Springs quad "angle.

Oder, like Ulrich, excluded all beds carrying Nolichucky trilobites from the Maynardville and limited his formation to the aphanitic to fine-grained laminated slightly magnesian unfossiliferous limastones that occur in the top of the member in the sections north of Clinch Mountain. This in part accounts for some of the astonishing variations in the thickness of the Maynardville as given by Oder, for in some sections thin beds of coarsely crystalline limestone carrying trilobites occur high in the section above th a finer grained unfossiliferous limestones which he thought characteristic of the member. 
The Maynardville, as interpreted by the writer, is different from Ulrich's and Oder's concepts; he considers it the upper member of the Nolichucky shale and includes in it the bulk of the limestones and magnesian limestones occurring between the shale of the lower Nolichucky and the cherty dolomite of the Knox group.

The Maynardville is a highly variable unit and exhibits regional facies changes that throw much light on the sedimentary history of the Appalachian Valley and are in harmony with facies relationships observed in older and younger strata. In the sections northwest of Clinch Mountain along Chestnut and Copper Ridges, the lower portion commonly consists of thin- to thickbedded fine to coarsely crystalline dark-blue limestone. Some layers contain beds of edgewise conglomerate, some are oolitic, and many are highly fossiliferous. Bedding surfaces are commonly rough and uneven, and the limestone units are separated by various amounts of shale of the Nolichucky type. One conspicuous bed of black oolitic chert in the Maynardville limestone member is represented by unit 167 of the Thorn Hill section (Hall and Amick, 1934, p. 167) and by unit 76 of the Lee Valley section (Rodgers and Kent, 1948, p. 13). What appears to be this same bed has also been recognized at many other localities, and it is the lowest conspicuous bed of oolitic chert observed in the stratigraphic column in this part of the Valley. The individual ooids are large, ranging from 1 to 2 millimeters in diameter.

In the upper part of the member, the limestones are fine grained to aphanitic, subcrystalline, light colored, laminated, and somewhat magnesian. Shale partings are fewer and much thinner and more highly calcareous than those lower in the section. In places a thin shale parting marks the contact with the overlying Copper Ridge, but more commonly the contact is drawn at the base of the massive, more coarsely crystalline dark dolomites. The dolomite beds in the Maynardville weather light gray, almost white, and the fine laminations stand out in low relief on most weathered surfaces. These beds are magnesian limestones rather than true dolomites and are almost totally devoid of chert. They are included in units 159 to 202 of the Thorn Hill section.

In the Mascot belt in the vicinity of Rutledge, the crystalline fossiliferous limestones in the lower part of the member are overlain by a great thickness of massive, compact sublithographic light-gray unfossiliferous limestone, which is well exposed in the quarry at the top of the hill on State Highway 92, about 2 miles south of Rutledge (Dutch Valley quadrangle, see section, p. 15). The contact with the Copper Ridge is concealed, but its approximate position is readily ascertained by the abrupt appearance of abundant residral chert in the soil. The member thins in a short distance to the southwest, along the strike, and is barely present in the area between Millertown and Loves Creek (John Sevier quadrangle).

In the southeastern part of the area, along Shields Ridge in the New Market and Jefferson City quadrangles, the Maynardville member consists of two units composed mainly of medium to coarsely crystalline dark-blue somewhat fossiliferous limestone, separated by a thick unit of shale-similar in all respects to that of the underlying mass of the Nolichuck 7 - and also separated from the overlying Copper Ridge dolomite by a similar but thinner shale unit.

The limestones in this section are more heterogeneous in color and texture than in the sect:ons farther north. It is especially noteworthy that magnesian limestones are almost wanting, and that beds of coarsegrained fossiliferous limestones overlie beds of lightcolored fine-grained to lithographic limertones. The percentage of shale in these sections is also rauch greater than in those farther north. It seems that from north to south there is a gradual increase in the amount of pure limestone, as contrasted with magnesian limestone; an increase in the proportionate amount of coarsely crystalline limestone present in the section and a decrease in the amount of fine-grained aphanitic limestone; and an increase in the proportion of shale present.

Very little chert is produced by the weatl aring of the Maynardville member or by any of the pre-Knox formations, but chert is abundant in the residual soil over all the formations of the Knox group. At some places, the upper part of the Maynardville, consisting of very pure chert-free fine-grained to aphanitic dolomitic limestone, leaches to a banded chert-free clay, the banding being interpreted as traces of the original bedding. Such clay has been observed at many places within the Mascot district. At one time it was well erposed along State Highway 92 about $21 / 2$ miles north of Jefferson City, at the point where the highway crossed the divide on the west side of Mossy Creek; these exposures are now covered by Cherokee Dam and Lake. It was also noted in creekbank exposures along Legg and Strong Creeks in the John Sevier quadrangle and at many other places. Normally, where the clay is found, the upper beds of the Maynardville member fail to crop out, but the basal beds of the Copper Ridge are vell exposed. In other areas, notably along Richland Knobs and Shields Ridge, the fine-grained limestones of the Maynardville resist solution more than the ccarse-grained dolomites of the Copper Ridge, and commonly they crop out, forming the crest of the ridge, whereas the Copper 
Ridge is represented on the south slope of the ridge by an orange-red cherty soil in which there are few outcrops.

The contact of the Maynardville limestone member with the main body of the Nolichucky shale is gradational, and it is drawn at that level in the section above which limestone predominates over shale. It is a facies and not a time boundary.

The contact between the Maynardville and the overlying Copper Ridge dolomite is marked by a change in types of rock. Below the contact there is blue crystalline commonly fossiliferous limestone of the type common in the Maynardville (and found locally, though rarely fossiliferous, in the Maryville and Rutledge limestones) or fine-grained thin-bedded wellstratified light-colored noncherty unfossiliferous somewhat calcitic dolomite. Above the contact there is more coarsely crystalline rather heavy-bedded poorly stratified virtually unfossiliferous dark dolomite typical of the Copper Ridge. The contact is not abrupt. The rock types alternate through a zone of several feet; there is no evidence of a disconformity. Oder states that in sections along the west side of the Valley of East Tennessee the contact is "usually marked by 2 feet of dark-gray, shaly dolomite, with an undulating upper contact" (Oder, 1934, p. 475). Such undulating contacts are common throughout the lower Paleozoic sequence in the Appalachian Valley, and no especial importance is to be attached to most of them. For convenience in mapping, the writer has consistently drawn the base of the Copper Ridge dolomite at the base of the lowest bed of dark coarsely crystalline dolomite; this practice has been followed by most field parties in recent years. The advantages of this boundary are

1. The first appearance of the dark coarse dolomite reflects a change in the conditions of sedimentation; it is readily picked in well-exposed sections.

2. The dark coarse dolomite produces much chert on weathering; therefore the boundary can be readily determined in areas covered by residual materials by mapping the edge of the residual chert.

3. The boundary lies between the upper limit of the Aphelaspis fauna, which is the highest of the Dresbach faunas and is here confined to the Maynardville, and the lower limit of Franconia faunas, representatives of which are found sparingly in the Copper Ridge. Thus it corresponds to an important faunal change that has been recognized and used as a datum plane over a large part of North America.

As thus drawn, the boundary is one of the more easily recognized and mapped contacts in the area. In the Thorn Hill section it is placed at the base of unit 203 of the Hall and Amick section (1934). This is essentially the contact pointed out to the writer in 1929 by Ulrich as the boundary between the Cambrian and "Ozarkian" systems, and he believed that a great unconformity existed at this contact.

The following detailed sections show the character of the Maynardville member in the Mascot-Jeff $3 x$ son City district and adjoining territory.

New type section of the Maynardville limestone member of the Nolichucky shale, exposed on the south side of State Highway 33 , between the briage across Cox Branch and the Clinch River bridge across Norris Lake ( $p l . s B$ )

[Measured by Josiah Bridge, probably about 1938]

Copper Ridge dolomite:

Covered interval, concealing possibly $50 \mathrm{ft}$ of beds. Hillside above road is strewn with chert float of Copper Ridge type, and there are scattered outcrops of coarse-grained dolomite. No outcrops in road ditch.

Nolichucky shale :

Maynardville limestone member:

47. Limestone, blue, fine-grained, heavily bedded with gray, coarser grained mottlings. This limestone is similar to rocks in unit 32 , and the gray mottlings are evidently a weathered phase of the buff and tan mottlings in the lower beds

46. Dolomite, dark-bluish-gray, finely crystalline; weathering moderately light, thick bedded, laminated, the laminae standing in low relief on weathered surfaces. A few layers of irregular soft porous siliceous nodules along the bedding planes in the upper portion of the unit

45. Shale, olive-green, hard, well-bedded, with thin dolomite layers near top. Hand specimens would be indistinguishable from the bulk of the Nolichucky shale

44. Dolomite, similar to unit 46 but without the siliceous nodules

43. Limestone, light-blue, fine-grained, becoming dolomitic toward the top---

42. Dolomite, similar to unit 46 but without siliceous nodules; shaly at top and base

41. Limestone, dove-colored, sublithographic, massive

Feet inches

Shale, olive-green, hard, well-bedded, with thin platy fine-grained limestone layers averaging less than 1 in. thick

39. Dolomite, like unit 46

38. Shale, olive-green, hard, with thin platy layers of dolomitic limestone

37. Dolomite, dark bluish-gray ; weathering light colored, finely crystalline, heavy bedded, finely laminated..---

36. Limestone, dark-blue, finely crystalline

35. Dolomite, like unit 37

34. Limestone, like unit 36

33. Dolomite, similar to unit 37 
Nolichucky shale-Continued

Maynardville limestone member-Continued

32. Limestone, dark-blue, weathering to bluish gray, finely crystalline to sublithographic, with broad irregular tan and buff stripes and mottlings arranged roughly parallel to the bedding surfaces

31. Dolomite, similar to unit 37

30. Limestone, light-blue to dove-colored, fine-grained to sublithographic, mottled and striped

29. Limestone, dark-blue, crystalline, oolitic and conglomeratic; pebbles of limestone, seemingly from the underlying beds, flat, as much as 6 to $8 \mathrm{in}$. long; most abundant in lower $10 \mathrm{in}$. of unit

28. Shale, greenish-gray, hard; well-stratifled with thin layers of dark-blue fine crystalline laminated dolomite

27. Dolomite, finely crystalline, laminated, dark-blue-gray, weathering light; locally crossbedded; one layer of stylolites

26. Limestone, dark-bluish-gray, with tan stripes and mottlings similar to unit 32 ; upper part badly shattered..-.-

25. Limestone, light-dove-gray, fine-grained to sublithographic; in some places showing mottlings as above, other places with no traces of bedding -...

24. Limestone, blue, crystalline, somewhat banded, massively bedded.

23. Limestone, dark-blue, somewhat banded with irregular buff and tan stripings and mottlings similar to unit 32 ; rather poorly exposed...

22. Limestone, dark-blue, coarsely crystalline, magnesian, with few but broad bandings and mottlings_-.--.

21. Limestone, dark-blue, finely crystalline to sublithographic, with buff and tan stripings and mottlings as in unit 32

20. Shale, olive-green, hard, well-stratified.

19. Limestone, finely crystalline to aphanitic, massively bedded, with irregular tan stripes and mottlings similar to those in preceding units, a 2-ft

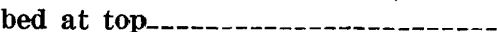

18. Covered interval.

17. Limestone, blue, nodular.

16. Shale, olive-green, hard, well-stratified -

15. Limestone, similar to unit 19.......

14. Covered interval

13. Limestone, similar to unit 19 , largely covered

12. Shale, olive-green, hard, well-stratified

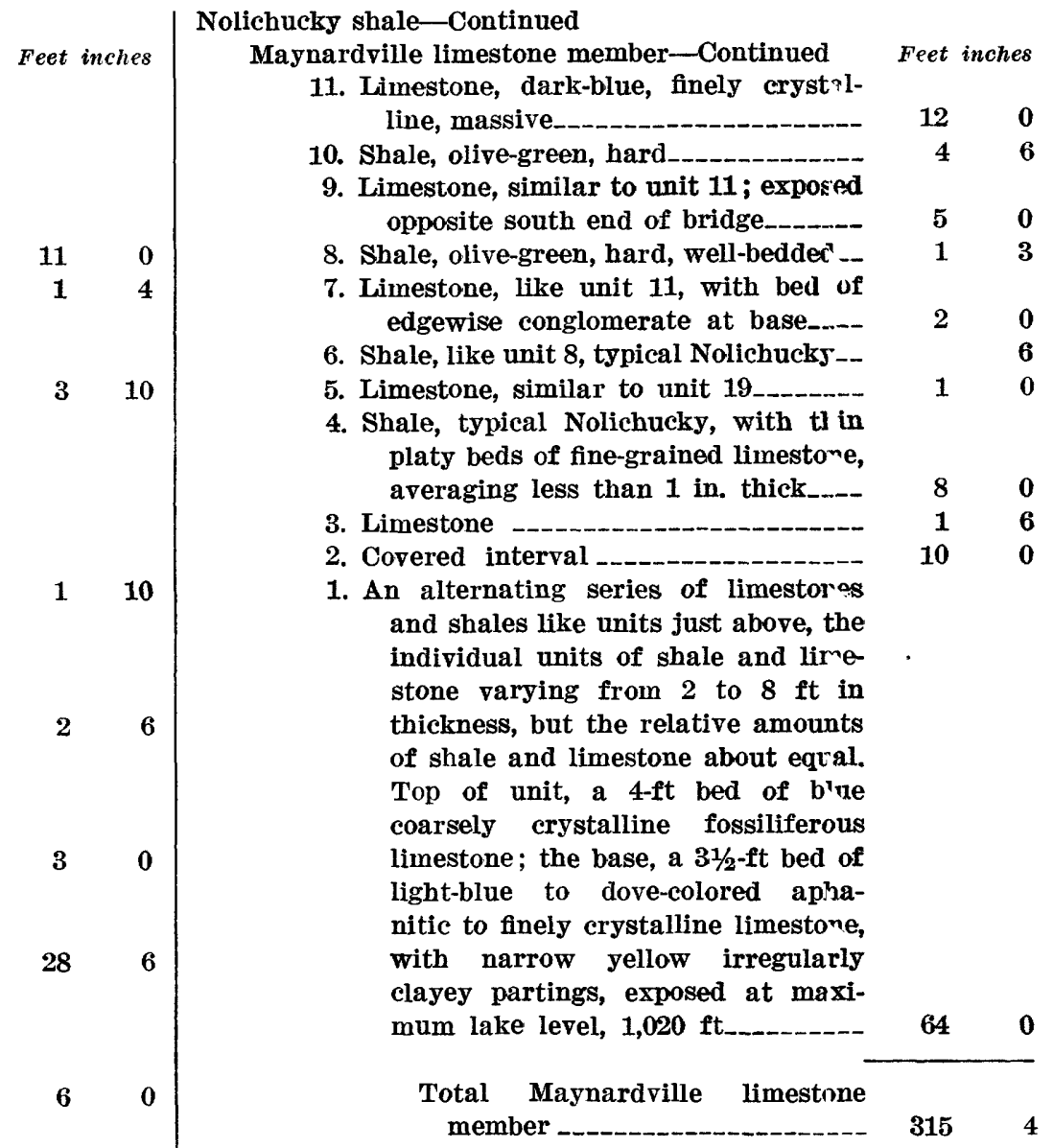

At low stages of Norris Lake a part of the underlying section is exposed; it consists of alternate beds of shale and limestone much as in unit 1 , lut the thicknesses of the individual units are greater, and shale predominates. This is considered the rpper part of the shale member of the Nolichucky shal?.

This section can be divided into three major parts. At the base is a division about 124 feet thick (units 116) composed of alternating beds of limestone and shale in about equal amounts. This is overlain by a division 103 feet thick (units 17-26) concisting almost Finally an upper division about 88 feet thick (units $27-47$ ) is composed of alternating beds of shale, limestone, and noncherty dolomite. This gradation from shale and limestone, to limestone, to limestone and dol-

omite is characteristic of sections in the northwestern part of the Valley.

Although the upper contact is not exr osed, it seems certain that the base of the dark coarse-grained cherty Copper Ridge is not far above the last limestone cropping out along the highway. Scattered outcrops show that a large part of the covered interval above the measured section is occupied by coarse-grain ad dark dolo- 
mite, a type of rock characteristic of the Copper Ridge. The hillside is also covered with abundant chert float, which is not derived from the Maynardville or any older unit.

The lower contact is taken at about the point below which shale is the predominant lithologic type; it could have been drawn at the base of some other limestone unit either higher or lower in the section. In the Thorn Hill section (pl. $3 A$ ) the writer refers units 136 to 202 to this member (Hall and Amick, 1934, p. 166-168). The total thickness is 168 feet 9 inches. In the Lee Valley section, units 69 to 85 with a total thickness of 181 feet are assigned to this member (Rodgers and Kent, 1948, p. 13-14). The gradations from limestone and shale, through limestone, to limestone and magnesian limestone with subordinate amounts of shale are much the same as in the type section, although the entire unit is much thinner.

The Maynardville limestone member is fairly thick along the northern edge of the Mascot-Jefferson City area and forms the crest of the north-facing escarpment known as the Richland Knobs that extends northeastward just south of U. S. Highway 11-W from the vicinity of Blaine in Grainger County to a point a few miles east of Tate Springs, near the Grainger-Hawkins County boundary (see Luttrell, Dutch Valley, and Bean Station quadrangles). The lower part of the member is well exposed along State Highway 92, about 2 miles south of Rutledge (Dutch Valley quadrangle), where the following section was measured:

Section of the lower part of the Maynardville limestone member of the Nolichucky shale, measured in State Highway Department rock quarry on State Highway 92, and along the highway at top of hill 2 miles south of Rutledge, Tenn.

[Measured by Josiah Bridge, 1940]

Top of quarry.

8. Limestone, exposed in back wall of quarry, subcrystalline to lithographic, light bluish to pearl gray, often mottled with buff and pink tones. Thick bedded, the individual layers 8 to $10 \mathrm{ft}$ thick. Individual layers often finely and indistinctly laminated, the laminations more conspicuous on weathered surfaces. Laminations often wavy, sometimes contorted, apparently caused by thin films of clayey and organic matter. In the lower 15 or $20 \mathrm{ft}$, toward the edges of the quarry are large irregular gray to buff-colored masses of finegrained dolomitic material, of irregular shape and size, evidently a selective replacement of the limestone. Thickness to fioor of quarry

7. Limestone, exposed along road at north end of quarry, similar to the preceding, with fine irregular yellow laminations; weathers smooth and to a light bluish gray
6. Covered

Feet inches

1

5. Limestone, fine-grained to aphanitic, dove-colored, with semiconchoidal fracture; beds as much as 4 in. thick, but averaging 1 in. Massive on fresh surfaces; bedding developed by weathering. Bedding irregular, gently wavy

4. Shale, thin-bedded, fissile, olive-green, weathering to small, thin, rusty, and yellowish flakes, interbedded with thin layers of platy aphanitic to finely crystalline limestone, the individual layers less than 1 in. thick

3. Limestone, a single bed of edgewise conglomerates; matrix of aphanitic to finely crystalline light-bluish limestone, pebbles of the same material as much as 1 in. thick and 6 in. long. Thickness of bed variable, average

2. Shale, similar to unit 4 , but without the limestone partings

1. Limestone, fine-grained to aphanitic, light-gray to dove-colored. Bedding slightly irregular, wavy. Some layers weather to smooth surfaces, others to a rough matte surface. Strike N. $40^{\circ}$ E., dip $10^{\circ} \mathrm{SE}$

Below unit 1 the limestone units are fewer and thinner and finally give way to a mass of shale that makes up the great bulk of the Nolichucky. The lower contact of the Maynardville member in this section is gradational and for convenience is drawn at the base of unit 7 , thus giving a thickness of 70 feet for the part exposed in the quarry. The section extends 140 feet abc ve the floor of the quarry to the top of the knob to the northeast and, as the average dip is $11^{\circ}$, this part of tl a unit has a minimum thickness of about 250 feet. Similar beds also crop out at intervals along the highway between the quarry and a point 0.25 mile north of Hammer Store (Joppa quadrangle). If the dip remains constant, the computed thickness of the Maynardville member in this section is at least 350 feet. The upper contact cannot be located definitely, but the characteristic residual cherts of the Copper Ridge dolomite cover the hillsides between the last outcrops seen and Hammer Store, and a few yards south of the store there are outcrops of typical Copper Ridge dolomite.

About 33/4 miles southwest, along the road trrough Owl Hole Gap (northwest corner of Joppa quaddrangle), the contact is fairly well indicated ly the abrupt change from outcrops to residual cherty clays. Strata believed to lie near the top of the Maynardville are exposed in a roadside quarry in Owl Hole Gap. In

this quarry several small veinlets of sphalerite. have been found by Robert A. Laurence. The quantity is insignificant, but the locality is of interest as the only reported occurrence of sphalerite in the Maynardville in 
the Mascot-Jefferson City district. A short distance south of the quarry all outcrops disappear, and roadside cuts show only residual clays and cherts of the Copper Ridge dolomite. This somewhat abrupt change from ontcrops to residuum is characteristic of the Maynardville-Copper Ridge contact over much of the Mascot-Jefferson City area.

In the southern part of the district, the Maynardville member is thinner, and its limestones are commonly more crystalline, resembling more closely those of the upper Nolichucky. The following section, measured in the southern part of the New Market quadrangle, will serve to illustrate this phase:

Section of the Maynardville limestone member of the Nolichucky shale, measured along the secondary road between Rocky Valley and Piedmont, 0.9 mile south of Rocky Valley Church

[Measured by Josiah Bridge and C. R. L. Oder, October 1940]

Copper Ridge dolomite: Lower part of formation forms top of Shields Ridge.

25. Covered, orange to red residual clays with fragments of black-banded cherts showing cryptozoan structures.

24. Largely covered but road cuts show thin platy black cherts in clay, preserving a rude orientation, which is interpreted as stratification modified by slump. At the base a thin platy brown sugary sandstone, 1 to 2 in. thick, also not definitely in place. This is taken as the base of the Copper Ridge. Calculated thickness

Nolichucky shale:

Maynardville limestone nember :

23. Largely covered, but with a few small outcrops of greenish calcareous shale of Nolichucky type. The most prominent of these is about 10 ft above the first limestones. Calculated thickness

22. Limestone, dark-bluish-gray to leadcolor, slightly magnesian, weathers dull gray. Fine grained, finely laminated, the laminations accentuated by weathering, rather evenly bedded, beds from 6 in. to $2 \mathrm{ft}$ thick, a conspicuous 3-in. shale parting 9 in. below the top, other thinner partings throughout the mass.

21. Covered (possibly shale)

20. Limestone, similar to the above, with a few beds and lenses of light-gray fne-grained dolomitic limestone..-

19. Covered

18. Limestone, similar to unit 20
Nolichucky shale-Continued

Maynardville limestone member-Continued

17. Limestone, medium to finely crystalline, heavy-bedded, minor beddiro irregular; contains irregular dol?mitic lenses, rarely more than an inch thick, which weather light ccrored and stand out in low relief. Strike N. $55^{\circ}$ E., dip $30^{\circ}$ SE. Forn's summit of pass. Fossiliferous, contains typical upper Nolichucky tril?bites

16. Limestone, shaly, fine-grained, thinly and irregularly bedded becomiro more massive toward the base

15. Shale, hard, platy, fissile, blue to olive when fresh, weathering greenirh buff. Contains a few thin beds of fine-grained platy sparingly fossiliferous limestone. Unit incornpletely exposed

14. Limestone like unit 17. Alternatir $\%$ irregular layers of medium-crysta.lline dark-blue, and finely crystallirg dull-blue-gray limestone, the latter weathering shaly and occasionally more nearly pure shale than lim?stone; lowest bed a massive crystalline limestone $2 \mathrm{ft}$ thick. Nolichucky trilobites in the more cry talline layers

13. Shale, hard, platy, olive-green

12. Limestone, like unit 14, a single massive layer exposed at bend in road.-

11. Shale, hard, platy, olive-green, upper part poorly exposed, fossiliferous_-.-

10. Limestone, fine-grained to aphanitic; the two varieties intricately mottle-, light bluish to pearl gray; massive, the individual beds 8 to $10 \mathrm{ft}$ thick but splitting into thinner slabs where weathered; fracture variable, suhconchoidal to splintery; weathe"s dirty grayish white, with yellow mottlings which seem to represent tl ? more crystalline part of the origin? rock. Exposures almost continuous. This limestone is identical with that exposed in units 7 and 8 in the se?tion south of Rutledge (p. 15)

9. Covered, but exposed in woods abore the road. Similar to unit 10.

8. Limestone, similar to unit 10 , but gradually becoming more coarsely cryst lline in texture and darker in color, toward the base, the lowermo beds greatly resembling those in units 16 and 17 above the big shale break... 
Nolichucky shale-Continued

Maynardville limestone member-Continued Feet inches

6. Limestone, dark- to medium-blue, finely to medium crystalline similar to lowest beds of unit

Total Maynardville limestone member

Lower shale member:

5. Shale, hard, thin-bedded, olive-green

4. Limestone, crystalline, like Maynardville

3. Shale -

2. Limestone -..--

1. Shale, calcareous, platy with a few thin limestone partings

Estimated thickness to base of Nolichucky shale

Total lower shale member

Total Nolichucky shale.

The Maynardville member is well exposed at many other localities outside the Mascot-Jefferson City area. The type area north of Maynardville and the Thorn Hill section have been discussed. Dolomitized limestone in the lower part of the Maynardville member is exposed in the workings of the old lead-zinc mine at New Prospect (Ausmus quadrangle; Kent, Rodgers, and others, 1945 , erroneously state that the mine is in the upper dolomitic part of the Maynardville), and at one time there was an excellent section of the lower limestone part of the member (not dolomitized) between the mine and the old bridge across Powell River (Keith, 1901, geologic map). Most of this section is now covered by Norris Lake. According to Rodgers the total thickness of the Maynardville in this area is 350 feet. Keith (1901) included all the dolomite and nearly all the limestone beds in this area in the Knox dolomite.

Another good section is exposed in the Knox County workhouse quarry on Blackoak Ridge at Tecoy (Bearden quadrangle). The limestone is highly fossiliferous at this locality and yields a fauna similar to that found on Shields Ridge. Still another good exposure is in another Knox County quarry (Biagiotti quarry), on the northwest side of Rogers Ridge, about 0.7 mile northwest of Bethlehem Church (John Sevier quadrangle). This is within the mapped area, but it is just north of the Saltville fault that bounds the northern edge of the Mascot belt. Strata of equivalent age are exposed around the Straight Creek mine (Clouds quadrangle), along the Kingsport-Gate City highway 2 miles north of Kingsport (Kingsport quadrangle), and along Gass Creek 1 mile northeast of Greeneville
(Greeneville quadrangle). The last two localitis are described by Oder and have not been studied in detail by the writer.

The Maynardville member shows considerable variation in thickness, which is what would naturally be expected if the interpretation of the member as a calcareous facies of the Nolichucky shale is correct. Oder $(1934$, p. $475,494,497)$ gives the thickness as between 60 and 250 feet, allowing 120 feet for the thickn'ss in the Thorn Hill section (units 147-202 of Hall and Amick, 1934), and 250 feet for the section on Jockey Creek in Greene County. He does not give the thickness in the type section. As previously stated, the present interpretation includes a greater thickness of beds at the base. The measurements in 6 sections here discussed are-new type section on Highway 33 , 31: feet; Thorn Hill section, 172 feet; Lee Valley section, 181 feet; section along Slate Highway 92, south of Rutledge, about 350 feet (calculated thickness) ; section on Loves Creek, north of Caswell, about 300 feet; saction on Shields Ridge southeast of New Market, 33i feet. Large variations from these figures have been noted elsewhere in the Valley, and they suggest that Oder's minimum figure is correct.

Ulrich (1911, p. 636) estimated the thickness of his lower Knox in the Thorn Hill section at 345 feet.

\section{GENERAL FEATURES}

FACIES RELATIONSHIPS

The limestone units of the Rutledge, Rogersville, Maryville, and Nolichucky formations show many lithologic similarities, and, in isolated outcrops where the sequence cannot be determined, it is commonly difficult to identify the particular formation to which the outcrop belongs. In general, the limestones of the Rutledge are more dolomitic, and those of the Maynardville member of the Nolichucky contain a greater variety of lithologic types and locally many thin shale layers. Certain types of limestone are common in all these formations however, and the entire sequence was probably deposited in a relatively constant environment in which the proper conditions of deposition were frequently repeated. The most abundant type is a dark-bJue to black finely crystalline massively bedded noncherty limestone that appears to be quite uniform in composition and texture when seen in fresh exposures. It is commonly quarried as a source of crushed store for roadbuilding; some layers yield large blocks the.t can be sawed and polished and used as a decorative marble.

Weathered outcrops are light bluish gray in color and commonly display a characteristic mottling of lighter and darker colored stripes and patches. Limestone showing this mottling is made up of an intricate mix- 
ture of two types of rock, the difference between which is almost invisible on freshly broken surfaces but is brought out conspicuously by weathering. The two types of rock differ in grain size: one type is composed of very fine calcite crystals visible only under low magnification, averaging 0.04 millimeter in diameter; the other type is composed of coarser crystals of dolomite (with a little calcite), quite distinct to the unaided eye, averaging 0.1 millimeter in diameter. The finer grained variety may be slightly silty. The two types generally are arranged in rather irregular layers 0.25 to 0.5 inch thick and roughly parallel to the bedding, but the coarser material lenses in and out through the fine and is much more abundant at some levels than at others. The coarser material weathers to lighter shades than the fine and on weathered face perpendicular to the bedding produces an unusual and highly characteristic striped and mottled appearance. On strongly weathered faces the coarser grained lenses commonly stand out in high relief. Weathered bedding planes show an irregular mottling, and in some places branching anastomosing rodlike masses that strongly resemble fucoids. No limestones in the Knox group possess these peculiar textures or weather in this fashion; and the occurrence of such limestone in the four pre-Knox formations indicates that they are closely related, which is one of the reasons for excluding the Maynardville member from the Knox group.

Another similarity of the limestones of all four formations is the absence of appreciable quantities of chert in any of them. A single thin zone of black oolitic chert and one or two thin layers of rather soft, spongy chert nodules have been noted near the top of the Maynardville at a few localities (p. 12, 13), but in general the limestones and the deep red residual soils derived from them are remarkably free from chert. On the other hand, practically all the strata of the Knox group yield chert under most conditions, indicating an entirely different set of environmental factors during deposition. The absence of chert in the Maynardville is a second reason for grouping it with the lower chertfree strata and not with those of the Knox group.

Northeastward from the Mascot-Jefferson City district the Rutledge, Craig, and Maryville limestone units merge into a single limestone and dolomite unit, the Honaker, for the Rogersville shale ceases to be recognizable in Russell County, Va. Still farther northeastward, between Marion and Roanoke, Va., the Nolichucky shale is also replaced by limestone and ceases to be identifiable as a distinct unit; here the entire limestone and dolomite mass between the Rome and the base of the Knox group is known as the Elbrook dolomite (Butts, 1933, p. 6-7; 1940b, p. 67, 74).
Southwestward from the district, on the other hand, the limestones thin out and eventually disappear, the formations lose their identity, and the entire section between the Rome and the base of the Knox group is represented by a thick mass of calcareous shale with thin irregular limestone beds and lenses known as the Conasauga formation.

Thus it would appear that the limestones forming the Rutledge, Craig, Maryville, and Maynardville units are westward-trending tongues of a great limertone unit in the northeastern part of the Appalachian Valley, and that they interfinger with shale tongues-the Rogersville and the Nolichucky-that extend northeastward from the Conasauga formation. The sequence is one of the finest and clearest examples of intergrading facies known in the Appalachian region (see diagram on chart, Howell and others, 1944, but the limestone tongues should be shown at the southeast side of this diagram) and the fact that the Maynardville limestone member participates in this intergradation is a third reason for classing it with the formations of the Conasauga group, rather than with those of the overlying Knox group.

Still farther south in Alabama and Georgia other limestone and dolomite tongues invade the Conasauga shale (p. 26), but this does not alter the interpretation presented here.

The fossils found in the Maynardville are yet a fourth reason for grouping it with the Nolichucky shale rather than with the Knox group; this evidence is discussed below under paleontology (p. 19 ff.).

\section{TOPOGRAPHIC EXPRESSTON}

The alternate limestone and shale units of the Cambrian have a strong influence on the topography of the region which they underlie, so much so that on wellmade topographic maps, especially those cc mpiled from aerial photographs by the multiplex method, it is often possible to identify individual formations and groups of formations and to trace their approximate boundaries by the characteristic topographic patterns.

The topography developed on the Rome is quite.distinctive. The thick sandstones in the lower part of the formation are resistant to weathering, and, in areas where moderate or steep dips prevail, the formation forms long, narrow, rugged second-order ridges that rise from 300 to 500 feet above the valley f ors. These ridges are notched at intervals by wind and water gaps and are generally heavily forested becanse the soil developed over the Rome is not fertile. The deeply notched profile and the heavy forest cover are usually sufficient to distinguish a ridge over the Rome from one over the Copper Ridge dolomite. 
The Rutledge limestone commonly forms a valley at the foot of the dip slope of the ridge consisting of the Rome formation, though in some places, in areas of steeply dipping rocks, it may stand up as a low discontinuous ridge between valleys cut on the shales of the Upper Rome and Rogersville formations. The Rogersville shale forms a valley, commonly continuous with the one developed on the Rutledge. Where the beds are steeply dipping, the Craig limestone member may locally be identified by a row of low knolls scarcely more than 20 feet high. Where the dip is gentle, the Craig commonly forms a low but well-defined and persistent escarpment, the flat surface at its summit being developed on the upper shale member of the Rogersville and the basal beds of the Maryville. An excellent example of this scarp may be seen in the valleys of Ray and Richland Creeks, at the foot of the Richland Knobs escarpment, on the Joppa, Dutch Valley, and Avondale quadrangles. In areas where the rocks dip steeply (over $60^{\circ}$ ), the Maryville limestone, especially its upper part, forms a low steep-sided, narrow ridge cut by many water gaps. The Nolichucky shale forms a distinct valley behind the ridge, and the Maynardville member beyond forms a second, parallel, lower and less definite ridge, generally merely a row of spurs. Good examples of these features occur on the John Sevier quadrangle in the area north of Mascot and south of U. S. Highway 11-W, also on the Luttrell quadrangle south and east of Blaine. Where the dip of the strata is gentle, the Maryville forms a steep but strongly dissected scarp along one side of the valley, the basal part of the Nolichucky forms a much dissected bench at the top of the Maryville, and the remainder of the formation rises in a steep escarpment capped and upheld by the Maynardville limestone member and the Copper Ridge dolomite. This sequence is well shown in the Richland Knobs escarpment on the Luttrell, Joppa, and Dutch Valley quadrangles beyond the limits of the map, and on the north face of Shields Ridge on the New Market and Jefferson City quadrangles. The topographic profile is highly characteristic and easily identified and has been recognized on many of the new TVA quadrangles between Knoxville and Bristol.

\section{PALEONTOLOGY AND CORRELATION}

Many of the fossils found in these five formations have been listed and figured by Resser (1938). Butts (1926, p. 67, 72-78, pls. 5, 8, 9; 1940b, pt. 2, pls. 65-67) has figured many of the species and has discussed their distribution in equivalent strata in Alabama and Virginia ; Resser and Howell (1938) have figured and described the Lower Cambrian faunas of the Appalachian Valley.
The Rome formation is classed as chiefly Lower Cambrian, ${ }^{6}$ the Rutledge, Rogersville, and Mar' formations as Middle Cambrian, and the Nolicl ucky shale as Upper Cambrian. The regional correlctions of these formations have been discussed by hesser (1938), and a somewhat revised correlation has appeared on the Cambrian correlation chart, prejared by the Committee on Stratigraphy of the National Research Council (Howell and others, 1944).

The relations of Nolichucky and Maynardville to each other and to the Copper Ridge are the only ones pertinent to the present report.

The Nolichucky shale, including the Maynardville limestone member, is highly fossiliferous and is correlated with the Dresbach formation ${ }^{7}$ of the Upper Mississippi Valley and its equivalents elsewhere in North America. The Cedaria, Crepicephahus, and Aphelaspis faunal zones, which characterize the Dresbach formation as here defined, are present in the Nolichucky shale. The Cedaria zone is found in the lower part of the shale member, and the species listed by Hall and Amick (1934, p. 166) from several levels in their unit 131 all belong to it. The Crepicephalus zorg occurs higher in the shale member, and elements of it are sometimes found in the lower part of the Maynardville limestone member. The number, kind, and relative abundance of species differ from shale to limestors.

The Aphelaspis fauna, as far as now known, is confined to the Maynardville limestone member, but it has not been found in all sections. Inasmuch as there is little or no evidence for unconformity at the top of the Maynardville, the failure to find this fauna at some localities is most probably due to a shift in facier that permitted the deposition of fine-grained unfossiliferous lime muds, now preserved as magnesian limestones. The fossils differ markedly in abundance from lithology to lithology ; they are most abundant in coarse-grained limestones, extremely rare in the aphanitic, sublithographic varieties, and virtually unknown in the magnesian limestones. Even in the coarsely crystalline strata, the fossils commonly occur in richly fossiliferous beds or lenses separated by barren areas of otherwise similar rock. Inasmuch as most of the fossils are dissociated fragments of trilobite tests, these accumulations are interpreted as the result of current

\footnotetext{
- Middle Cambrian fossils occur in the shale here classed as upper Rome. This shale corresponds to the Pumpkin Valley shale of rodgers and Kent $(1948$, p. $7-9)$, but the fossils were erroneously listed by Resser (1938, p. 27) as Rutledge.

7 The name Dresbach formation as used here conforms to thi usage of Trowbridge and Atwater (1934), and includes the Mt. Simcn, Ean Claire, and Galesville members. This is not the classification of the U. S. Geological Survey (Wilmarth, 1938, p. 631-632), but it conforms with generally accepted usage of Cambrian stratigraphers thrcughout North America (Howell and others, 1944).
} 
action. The scarcity of fossils in the fine-grained limestones is probably environmental, for it is well known that today areas of fine-grained lime muds are almost devoid of benthos.

Lochman and Duncan (1944, p. 31), discussing the ecology of these faunal assemblages, wrote:

Although a lack of knowledge of the physiologic processes of trilobites precludes a positive statement of water temperatures, the large diversified faunal assemblages of the Cedaria and Crepicephalus zones would by analogy indicate warm temperate conditions, while the assemblage of the Aphelaspis zone, rigidly restricted to five trilobite genera throughout the entire country, and represented by large numbers of individuals, may indicate the introduction of cooler waters.

Further, Lochman writes (personal communication) :

The Crepicehalus fauna contained a large number of species ; therefore some of the diagnostic forms are almost certain to be present, no matter what the lithology of the formation may be. It also appears that certain genera characteristic of the fauna, notably Crepicephalus, Uncaspis, and Llanoaspis, were able to live in environments containing quite a bit of clastic material; therefore species belonging to these genera are fairly well represented in shales and sandstones, as well as in limestones, and thus serve as a means of correlation between different facies.

In his discussion of the Upper Cambrian faunas of the Appalachian Valley, Resser (1938, p. 28-30) listed species occurring in the Cedaria and Crepicephatus zones, in eastern Tennessee, mentioned the presence of the Aphelaspis zone without listing its fauna, and stated that a fourth zone, his so-called Blountia zone, was present above the $A$ phelaspis zone. His list of species from this zone is lengthy and includes at least 8 forms known to be characteristic of the Aphelaspis zone, 23 known from the Crepicephalus zone, and a few species that are unknown in this part of the Cambrian and are thought to have been misidentified. Most Cambrian stratigraphers and paleontologists now believe that the socalled Blountia zone does not exist as a distinct unit, but that the fauna attributed to it is made up prinarily of species from the Aphelaspis and Crepicephalus zones, particularly those forms characteristic of coarsegrained limestones. This would account for the extraordinary development of the so-called Blountia zone in sections where such limestones are abundant and its scarcity or absence in sections where fine-grained limestones or dolomites make up the bulk of this member.

The lists of species characteristic of the Crepicephatus and Aphelaspis zones given below were prepared by Mrs. Christina Lochman Balk and have been checked for changes in generic assignments by her and A. R. Palmer.

All species listed are from the Appalachian Valley; those indicated (Va.) are known only from Virginia.
Aphelaspis zone

Aphelaspis camiro (Walcott)

hamblenensis Resser

laxa Resser

quadrata Resser

simulans Resser

tumifrons Resser

walcotti Resser (Va.)

Cheilocephalus breviloba (Walcott)

Raaschella appalachia (Resser) (listed by Resser as Stenochilina)

bristolensis (Resser) (Va.) (listed by Resser as

Terranovella)

Species listed by Resser that are probably referable to the Aphelaspis zone:

Blountia assimilis Resser

crassa Resser

Crepicephalus zone

Blountia alexas (Walcott)

anser (Walcott)

mimula (Walcott)

rogersvillensis Resser $=$ Blountiella lata Resser

Blountiella buttsi Resser (Va.)

Coosia robusta (Walcott)

Crepicephalus expansus Resser

rectiformis Resser

Kingstonia rotunda Resser

Llanoaspis blandensis (Resser) (Va.)

buttsi (Resser) (Va.)

campbelli (Resser) (Va.)

clinchensis (Resser)

peculiaris (Resser)

ulrichi (Resser)

virginica (Resser) (Va.) $=L$. rogersvillensis (Resser)

walcotti (Resser)

Maryvillia arion (Walcott)

keithi Resser

sp. $=$ Coosia alethes (Walcott)

Pemphigaspis appalachia Resser

Tricrepicephalus magnispinus (Walcott)

thoosa (Walcott)

walcotti Lochman

Uncaspis micans Resser

Species listed by Resser that probably belong in the Crepicephalus zone (ranges of those marked with an asterisk (*) may extend into the Cedaria zone) :

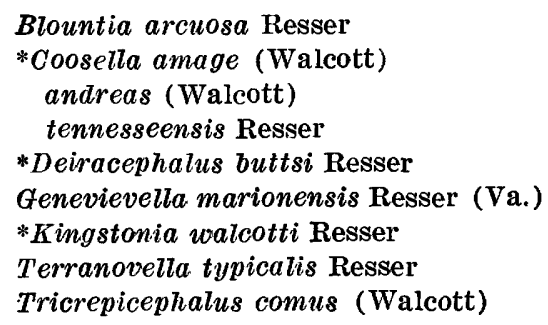

To the above lists should be added the species assigned by Resser (1938, p. 29) to the Crepicephahus zone. In compiling these lists a few okrious mistakes have been corrected, but no attempt has been made to eliminate possible homonyms and syronyms as this 
would involve a detailed paleontological study that is beyond the scope of this report.

Resser (1938, p. 28) also mentioned the presence of graptolites in some of the faunas from the Nolichucky shale. These are mostly dendroid forms and are commonly found associated with the Aphelaspis fauna in the Maynardville limestone member. One of the best localities is at the Knox County quarry at Tecoy (p. 17), but they have also been found at several other localities. Decker has studied this faunule but has not published a list of species.

\section{KNOX GROUP \\ GENERAL REMARKS DEFINITION}

The Knox group as used in this report comprises all strata above the Maynardville limestone member of the Nolichucky shale and below the Lenoir limestone or its Mosheim member. It is essentially the Knox dolomite of the Knoxville, Maynardville, and Morristown folios (Keith, 1895, 1901, 1896). The establishment of a satisfactory subdivision of the Knox dolomite was the major task undertaken when the author began the geologic work that led to this report. Such subdivision is important economically because mineral deposits in the Knox group are commonly confined to definite, rather thin, stratigraphic zones and at the same time are related to relatively minor structural features; therefore the more stratigraphic and structural detail that can be shown on a geologic map, the more valuable it will be to the mining geologist and mine operator and to any others who may have occasion to use it.

\section{HISTORY}

The history of the terminology of the Knox group and of the underlying and overlying formations is shown in chart 1. The columns of this chart list the names applied to Cambrian and Ordovician rocks in the publications cited, but the order is not necessarily that of the author cited; instead the names have been rearranged to show how the rocks included in the author's units are now classified. Thus, where a name, such as Sevier shale, was applied to two units now separately classified, the name appears in two places in the appropriate column. Similarly, Ulrich (1911, p. 637-638, pl. 27) places his Jonesboro limestone on the eastern side of the Appalachian Valley entirely above his "Upper Knox" on the western side; it is now known that the Jonesboro as originally defined includes the facies equivalent of the entire Knox sequence in the western belts, and it is so indicated on the chart.
Safford (1869, p. 203-226) proposed the term "J noxville or Knox Group" ${ }^{8}$ to include all the strata cronping out in the Valley of East Tennessee below the "Trenton and Nashville Series," now the Lenoir limeston: and higher formations. (The older Lower Cambrian quartzites and shales, which he assigned to the Chilhowee and Ocoee groups, do not crop out except in the mountains along the southeast margin of the valley.) In the group, he recognized three divisions: from below upward-the Knox sandstone, the Knox shale, and the Knox dolomite. This classification was used by others, notably the geologists of the early State Surveys of Alabama and Georgia (Smith, 1876, and many other publications).

The section that Safford considered "typical of the Knox Group" begins at the fault on "Webb's (or Rosebury's) Ridge, nearly three miles northwest from J'noxville, and extends to the Holston River. It is about three miles in length, and was taken along Sacond Creek." (Safford, 1869, p. 204 and fig.). W'ebb's Ridge is now known as Sharp Ridge. The saction crosses two belts of Knox dolomite, the northwestern of which is the southwest extension of the Mascot belt. Safford $(1869$, p. 205) gave a generalized section of the limestones and dolomites in this northwestern ridge and stated that their total thickness was 3,504 feet. This section is now entirely within the built-up part of the city of Knoxville-the valley of Second Creek is occupied by the tracks and yards of the Southern Railway-and at present little can be seen of the or:ginal section. The section on Loves Creek, about 6 miles northeast of Second Creek and in the western part of the area mapped for the present project, crosses the same belt of outcrop, and from it one can obtain a reasonably accurate picture of the Knox group of Safford in its type area. Even this is threatened by the growth of the city. A much better exposed section, and the one now commonly considered to be the most representative both of the Knox group of Safford and of the Knox group of present usage, is that at Thorn Hill, Grainger County (p. $25 ; \mathrm{pl} .3 A$ ).

In the 1890's the U. S. Geological Survey began to publish folios covering 30-minute quadrangles in the southern Appalachian region. In these, the Knox group of Safford was abandoned and new names were proposed for the two lower divisions. The upper third of the original Knox group retained the name of Knox dolomite. No attempt was made to map subdivisions within the Knox dolomite, although it was recognized

\footnotetext{
8 "The city of Knoxville is located on a ridge made un of its limastones and dolomites; and this circumstance, together with the fact tl at the threefold typical character of the series is well developed in Knox County, has induced me to name it the Knoxville, or the Knox Croup," (Safford, 1869, p. 204.)
} 
from the start that the formation contained both Cambrian and Silurian fossils. (At that time the term Ordovician period was not recognized by the U.S. Geological Survey.) The boundaries of the Knox dolomite were drawn on purely lithologic grounds, the presence of dolomite being the chief criterion. Thus it happened that, in Alabama, Georgia, and southeastern Tennessee, beds of pure limestone that are laterally equivalent to the upper third of the Knox dolomite farther north and northeast were excluded from the Knox and mapped with the overlying Chickamauga limestone. According to Butts (Butts and Gildersleeve, 1948, p. 18-19), the Chickamauga at its type locality contains the Newala limestone, which is equivalent to the Kingsport and Mascot formations of the present report. Similarly at the lower limit, beds of dolomite in central Alabama, now known to be equivalent to the Nolichucky and Maryville and perhaps also the Rogersville formations, and therefore older than the Knox dolomite of Safford and Keith, were mapped as, and considered a part of, the Knox dolomite. At the same time, equivalents of the Knox dolomite in States farther north received other names, such as Shenandoah, Natural Bridge, Kittatinny, and Conococheague limestones, and, owing to scarcity of fossils and the failure to utilize the few that were found, little progress was made for many years in correlating the rocks in the several areas.

The first attempt at correlation and subdivision of the Knox dolomite was made by Ulrich (1911, p. 633-640), who demonstrated that it could be zoned and divided. During the next two decades, a considerable amount of subdivision was accomplished in Alabama and Virginia through the detailed mapping of Butts $(1926 ; 1933 ; 1940 \mathrm{~b} ;$ Butts and Gildersleeve, 1948) and others (Woodward, 1932) aided by the paleontological work of Ulrich. The correlation of certain paleontological zones throughout the length and breadth of the Appalachian Valley was fully established, but little detailed mapping was done in Tennessee until the present investigation was started.

After the publication of the Revision of the Paleozoic Systems (Ulrich, 1911), Ulrich did not publish much concerning the subdivision of the Knox, but the subject was constantly in his mind. Some of the results of his studies are available in the form of correlation charts inspired by him and published by others (Bassler, 1915, pls. 1, 2; Gordon, 1924, p. 34; Secrist, 1924, p. 16; Ulrich and Cooper, 1938, pl. 58). For many years he was absorbed in regional stratigraphic studies of lower Paleozoic rocks in the Appalachian Valley and elsewhere in the eastern and central United States and was consulted on many occasions by geologists of the Federal and State Surveys as well as by many others who were interested in these problems. The inupress of his work upon studies of Appalachian stratigraphy will remain for a long time to come, and it is greatly to be regretted that he did not find time and or nortunity to publish more of his ideas. The writer was closely associated with Ulrich during the years that this study was in progress and is fully conscious and most appreciative of the help that this association $\varepsilon$,fforded. In spite of this, many of the interpretations presented herein are directly contrary to some of Ulrich's most firmly held convictions. This is regrettable but unavoidable as long as so many of the facts are unknown or at best imperfectly understood; at the same time it is fully realized that the results of this study are not final and that they will undoubtedly be modified and improved by subsequent workers.

In general, Ulrich believed that the sequence of formations and faunas in the Knox grouj is different in different areas; that facies changes are quite unimportant; that certain formations and their associated faunas are locally absent either because of nondeposition or because of subsequent uplift and erosion; and finally that formations are normally serarated from each other by disconformities. Butts, who was closely associated with Ulrich for many years, adl ared to these views during much of his earlier work in the Appalachian Valley, but he recognized several important facies changes (for example, between the Towville and Moccasin limestones and between the Conococheague limestone and the Copper Ridge dolomite).

As the present investigation progressec, and as the writer became familiar with the problems of the Knox group, the conviction grew on him that there are few, if any, unconformities of great magnitude within the Knox group; that the sequence of fauna: within the group is the same throughout the Appalachian Valley, at least in Tennessee; that any one of these faunas may be better developed or preserved and thus seemingly more abundant at one locality than at snother; and that this in turn may be due to the lithology of the rocks containing the fossils or to various environmental factors at the time of deposition.

It is now known that the Knox group contains the same series of faunas on both sides of the Valley, but that it is in a predominantly dolomitic facies on the northwestern side and a predominantly calcareous facies on the southeastern side. The interrening belts, among them the three belts included in the MascotJefferson City district, show various gradations between these two extremes. In general, an increase in the amount of dolomite in a given formation is accompanied by a decrease in the number of foss: Is preserved. Failure to recognize these facies relationships largely 
vitiated Ulrich's classification and correlation of the rocks of the Knox group, for, if fossils characteristic of a given unit were not recognized, the unit was presumed to be absent by unconformity. For example, Ulrich (1911, p. 671-674) considered the "Jonesboro" limestone on the east side of the Valley, which carries Canadian fossils in its upper part, to be much younger than the generally unfossiliferous dolomite on the west side, but when fossils were finally found in this dolomite they showed that the two sequences are to be correlated. Similar reasoning underlies Oder's remark that the Stonehenge limestone "intervenes between the Chepultepec formation and the Nittany [Longview] dolomite in the northeastern part of the valley, not being known elsewhere in the area" (Oder, 1934, p. 481), yet the fossils show that the Stonehenge and Chepultepec are facies equivalents within a single formation (Grabau, 1937, p. 66-67; Butts, 1940b, p. 101). Failure to take regional facies relationships into consideration was the cause of the unusual variations in thickness that Ulrich reported for certain formations, and also of the very great total thicknesses he assigned to the lower Paleozoic systems.

\section{PRESENT USAGE}

In this report the Knox group is divided into five formations, which are, in ascending order, the Copper Ridge dolomite of Late Cambrian age, and the Chepultepec, Longview, Kingsport, and Mascot formations of Early Ordovician age. (As previously noted, the Maynardville limestone of Oder is here considered to be a member of the Nolichucky shale and is excluded from the Knox group.) These formations are lithologic units; the confusion of formations with faunal units, that is, the definition of formations solely by their faunal content, has led to much of the confusion now existing in the correlation of the formations of the Knox group and of the overlying formations in the Appalachian Valley.

The names Kingsport and Mascot were chosen jointly by Bridge and Charles R. L. Oder for use in this report and a similar report being prepared by Oder on the area to the northeast. They were proposed by Oder and Miller (1945) and have been used in several abstracts and maps in the last few years. They replace the terms "Jefferson City formation" and "Cotter-Powell beds" used by Oder (1934) and also Forked Deer and Thorn Hill used by Hall and Amick (1934). Jefferson City, Cotter, and Powell are the names of formations exposed in Missouri and Arkansas, and there is no possibility that they can ever be traced into the Appalachian Valley. Even today, the limits of these three formations in their type areas and their relations to one another are not well known. More- over, no two workers define them with the same limits. It is true that the Kingsport limestone corresponds to some part of the Jefferson City formation of the Ozark region, and the Mascot dolomite corresponds to some portion of the Cotter, but there is no evidence to indicate that the Jefferson City-Cotter boundary is the same as the Kingsport-Mascot boundary; in fast, recent studies indicate that they are not exactly the same (Cullison, 1944). There is at present no evidence to indicate that any beds in the Appalachian Valley of Tennessee are equivalent to the Powell formation of the Ozark region; on the contrary, fossils from the top of the Mascot dolomite in several localities correlate it with the upper part of the Cotter.

The five formations into which the Knox gromp has been divided are generally recognizable within the Mascot-Jefferson City district and over much of the surrounding territory, but their recognition and delineation depend to some extent on the scale of the map on which they are to be shown. Moreover, they are not always easy to map because of similarities in litl ology from unit to unit, both in the bedrock and in the residual cherts, and because of lack of outcrops, co!luvial movement of residuum, and absence of fossils anc' other diagnostic criteria. Hence the boundaries on the geologic map are indefinite in many places.

For example, in the Mascot belt, the Chepultepec and Longview dolomites are both strongly dolomitic and can only be separated from one another with great difficulty, but in the area around Jefferson City the Chepultepec contains a great deal of limestone which makes it easier to differentiate. Similarly, the Jingsport and Mascot formations are reasonably distinct in the Mascot-Jefferson City district, the former being largely limestone, the latter dolomite. To the south and southwest of the Mascot-Jefferson City distrint, the percentage of limestone increases; in southern Tennessee, Georgia, and Alabama the two formations los' their identity in a great mass of limestone-the Newalc limestone. To the north and northwest, on the other hand, the limestone beds diminish in number and thirkness and, except for a few layers near the base of the J.ingsport, totally disappear, so that the separation of the two formations in the western belts of outcrop is also extremely difficult.

There is little evidence of an unconformity at the base of the Knox group. Although generally speaking it is fairly easy to separate the Maynardville frcm the Copper Ridge, in practice it is often difficult to draw the precise boundary, especially toward the western side of the Valley (see p. 13).

There is now ample evidence of an unconformity of some magnitude at the top of the Knox group in East 
Tennessee, though even here it is sometimes difficult to separate the uppermost limestones of the Mascot dolomite from the overlying Mosheim member of the Ienoir limestone. Fossils collected in the upper 50 feet of the Mascot at a few widely separated localities indicate that faunas of latest Beekmantown age, such as have been found in the Warm Springs Valley and at other localities in western Virginia, are not present in Tennessee. The Lenoir limestone, including the Mosheim member, carries a Chazyan fauna, and there does not seem to be a sufficient thickness of strata between the Mosheim above and the highest fossiliferous beds in the Mascot below to carry the upper Beekmantown (Cassin) faunas. Furthermore, a conglomerate occurs locally at the base of whatever unit overlies the Mascot dolomite; the pebbles of this conglomerate are chiefly chert fragments derived from the weathering of the upper formations of the Knox group and are clearly identifiable as such. This unconformity and the deposits upon it are discussed more fully below (p. 57-59).

The most probable break within the group itself is that between the Copper Ridge and Chepultepec dolomites, which corresponds to the break between the Cambrian and Ordovician periods, but even this break does not appear to involve a long interval of time as no faunas are known to intervene elsewhere.

\section{OZARKIAN AND CANADIAN SYSTEMS OF ULRICH}

Many of the papers cited in this report make frequent references to the proposed Ozarkian and Canadian systems of Ulrich. These systems, proposed by Ulrich in 1911, were never formally adopted by the U. S. Geological Survey. They were used, however, by a considerable number of geologists for three decades and were adopted either formally or informally by a number of State organizations. As a result, the names Ozarkian and Canadian have appeared in publications and maps issued by several State surveys and on certain maps and publications of the Geological Survey, at least as quoted from Ulrich. Since the death of Ulrich in 1944 and of Butts in 1946, these systems have received little support. But many questions concerning them are still unanswered, and, as the Mascot-Jefferson City district and East Tennessee lie in an area where these systemic terms were applied, some discussion is here devoted to them.

It may be stated at the outset that no evidence favorable to the recognition of the Ozarkian has been found in the course of this investigation. For the Canadian the results are more noncommital. A case for a somewhat enlarged Canadian system can be made if the establishment of a new system for the Lower Ordovician seems desirable; on the other hand there seems to be no valid reason for separating the so-callet Canadian rocks from the rest of the Ordovician, unless it be the unconformity at the top of the Canadian or Lower Ordovician. These results are not at all astonishing for, whereas the Canadian was simply split off from the early part of the Ordovician in order to lessen the amount of time allotted to that period and make it more nearly commensurate with other periods, notably the Silurian and Devonian, the Ozarkian was believed to be a new and hitherto unrecognized system wedged in between the Cambrian and the Canadian. It can now be stated that, with the possible exception of the Madison sandstone in Wisconsin, there is not a single formation among those assigned to the Ozarkian by Ulrich that cannot be and has not been properly correlated with formations that Ulrich hims olf placed in either the Cambrian or the Canadian. This seeming paradox came about because most of the formations assigned to the Ozarkian are predominantly dolomitic in character, whereas their equivalents elsewhere are limestones, shales, and sandstones. The dolomites, as always, are sparingly fossiliferous and many of the fossils found are those of forms adapted to this peculiar environment and hence at first sight seemingly differ-. ent from those found in the other rock tyras.

In defining the Ozarkian, Ulrich (1911, p. 627) included

all the formations in the Appalachian Valley that can be shown to be younger than (1) the top of the Upper Cambrian Nolichucky shale in northeastern Tennessee and (2) the top of the Conasauga shale in southeastern Tennessee, northwestern Georgia, and northeastern Alabama and which are older than the base of the Stonehenge limestone of the Canadian system in southern and central Pennsylvania.

Thus the Copper Ridge dolomite of Erst Tennessee and its equivalents elsewhere were considered to be of Ozarkian age. In more recent years, however, elements of a number of faunas of Late Cambrian age have been found in the Copper Ridge (p. 34 ff.), and it can now be shown that the formation is probably the equivalent of both the Franconia and the Trempealeau formations of Wisconsin and of their equivalents elsewhere.

The distinguishing feature of the Ozarkian faunas, according to Ulrich, was an association of trilobites of Upper Cambrian affinities with gastropods and cephalopods of Ordovician or Canadian affinities. Not all his trilobites, however, are distinctly Cambrian in character; in fact, those assigned to the upper Ozarkian are all types unknown in the Cambrian and all have definite relationships to the forms occurring higher in the Ordovician. The gastropods are about equally well represented on both sides of the period boundary. Their 
asseciation with the Cambrian trilobites in the lower Ozarkian is largely a matter of facies-the gastropods lived in a lime-mud environment, and, when this was invaded by trilobites, the characteristic Ozarkian assemblage was formed. Most formations recognized by Ulrich as being of Late Cambrian age are composed of crystalline limestones, shales, and sandstone. Trilobites are abundant in these rocks, but gastropods are comparatively rare. Even the trilobites vary in abundance, however, according to the type of sediment in which they are found. The well-known Upper Cambrian genus Dikelocephalus, once believed to be the index fossil for the Upper Cambrian, is actually restricted to a shale environment.

\section{COPPER RIDGE DOLOMTTE}

\section{NAME}

Ulrich (1911, p. 635-637) proposed the term "Copper Ridge chert" for his second division of the Knox dolomite of eastern Tennessee and southwestern Virginia. The name was taken from Copper Ridge, the long, narrow, monoclinal ridge at the northwest base of Clinch Mountain, recognizable as a distinct topographic feature from Russell County, Va., to a point some miles west of Knoxville." The type locality ${ }^{10}$ is along "the road from Bean Station ${ }^{11}$ to Evans Ferry, on Clinch River" (Ulrich, 1911, p. 636), now U. S. Highway 25-E. It is shown on the Morristown folio (Keith, 1896) and on the Avondale 71/2-minute quadrangle sheet of the TVA series (pl. $3 A$ ). No detailed section was included, but the approximate thickness of the various formations and some description of the lithology, paleontology, and correlation of each were given.

This remarkable section, commonly known as the Thorn Hill section from Thorn Hill P. O. at its southern end, exposes almost every foot of the beds included in the Knox group as well as a great thickness of the overlying and underlying strata. It is one of the best exposed most continuous sections of lower Paleozoic rocks in East Tennessee and is now considered the standard of reference for this region, not only for the strata

\footnotetext{
- East of the gap at Speers Ferry, Va., where Troublesome Creek cuts through the ridge to join Clinch River, this ridge is known as Moceasin Ridge, and the name Copper Ridge is transferred to the next structural belt to the northwest (see Estillville $\mathbf{3 0}^{\prime}$ quadrangle and the new Clinchport and Duffield $71 / 2^{\prime}$ quadrangles).

10 Wilmarth (1938, p. 519) states that the formation was "named for Copper Ridge, NE. of Knoxville, Tenn.," and Resser (1938, p. 17) says that "The type locality for the Copper RIdge formation is on Copper Ridge, Knox County, Tenn. (Ulrich, 1911)." Cooper (1944, p. 23) makes a similar statement. The only section of the formation on Copper Ridge mentioned by Ulrich in his original deseription is the one in Grainger County, discussed here, and Ulrich stated to the writer on several occasions that this is the section to which be was referring in the "Revision" and that he regarded it as the type section.

11 This locality is now submerged by Cherokee Lake, and Bean Station is in a new location, more than a mile to the west.
}

of the Knox group but for a number of older and younger formations as well. It differs in some details from the sections in the Mascot-Jefferson City district, and these differences are pointed out below in the descriptions of the various units. The section begins at a thrust fault about 700 feet north of the north end of the bridge across Indian Creek at the northwert base of Copper Ridge, where the Lower Cambrian Rome formation is thrust over the Moccasin limestone of Middle Ordovician age, and extends southward crossing Clinch Mountain to Poor Valley Ridge, where the Rome formation in the base of the next fault block to the south is thrust over the lower Mississippian Grainger formation.

The exposures in the older part of this section are practically continuous, and Hall and Amick (1934) measured a detailed section from the beds low in the Rutledge limestone exposed close to Indian Croek to the lowest red beds of the Moccasin limestone opposite Thorn Hill P. O. This was a bed-by-bed measurement using planetable, alidade, and steel tape and contains notes on the lithology and paleontology, but, although the Knox was divided into four formations and new names were applied to two of them, no discussion of formations or correlations was given. At the suggestion of the writer, Hall and Amick painted the numbers assigned to many of their units on the exposures. Many of these are still visible (1950) and make it eesy for anyone having their paper to orient himself in the section. Rodgers and Kent (1948) reinterpreted the section in the light of the further development of ideas by the writer and others, and correlated it with a similar one exposed along State Highway 66 at Lee Valley 16 miles northeast. In making these comparisons, they pointed out a few significant key beds missed by Hall and Amick and corrected a few errors in addition.

Oder (1934, p. 489-494) also measured and described this section, divided it into five formations, and correlated it with other sections in East Tennessee. These are the only detailed descriptions of the Copper Ridge dolomite in its type area that have been pullished. Hall and Amick's formations are not exactly the same as Oder's, and both differ in certain particulars from those used in this report.

As originally defined, the Copper Ridge incluted all the strata above Ulrich's "lower limestone" (roughly equivalent to the Maynardville limestone member of this report) and the base of the "Upper Knox" (Kingsport limestone and Mascot dolomite). It insluded, therefore, the Chepultepec dolomite and the Longview dolomite of this report. This was not Ulrich's intention but was due to failure to find the fossils characteristic of the Chepultepec and Longview in the Thorn 
Hill section; the absence of the fossils was considered evidence that the formations were missing because of a disconformity (see p. 22). Later the Copper Ridge dolomite was studied in greater detail in Alabama and Virginia by Butts $(1926$, p. 84-87; 1940b, p. 90-95) and Ulrich (mostly unpublished, but see charts in Bassler, 1915, pls. 1, 2; Gordon, 1924, p. 34 ; Secrist, 1924, p. 16; Ulrich and Cooper, 1938, pl. 58), and its position beneath the Chepultepec was clearly established. Subsequent work on the Thorn Hill section by Ulrich, Butts, Oder, the writer, and others has brought to light both the Chepultepec and Longview faunas in the upper part of the original Copper Ridge, and the formation in the type section is now restricted to the beds above the Maynardville limestone member of the Nolichucky shale and below the Chepultepec dolomite, more specifically to units 203 to 304 of Hall and Amick's section.

In Tennessee, Virginia, and northern Alabama the Copper Ridge is the oldest formation that has been assigned to the Knox group, but in central Alabama, particularly in the Cahaba Valley, other units, namely the Bibb, Ketona, and Brierfield dolomites, are believed by some (Ulrich, 1911, p. 633-634; Bassler, 1915, pl. 2; Butts, 1926 , p. 81-84; 1940a, p. 6) to lie above the Nolichucky shale or its equivalent but below the Copper Ridge dolomite. Other geologists, including the writer, believe that these formations, collectively known as the "Sixmile series" (Resser, 1938, p. 17), represent a dolomitic facies of the upper part of the Conasauga shale, being the stratigraphic equivalents of the Nolichucky, Maryville, and Rogersville formations of Tennessee, for the few fossils found in the immediately underlying Conasauga shale in the Sixmile area are Middle Cambrian forms similar to those found in the Rutledge limestone of Tennessee (Butts, 1926, p. 73, pls. 5, 8; 1940a, p. 5). If the Bibb, Ketona, and Brierfield were indeed younger than the Nolichucky shale and older than the Copper Ridge dolomite, then a notable disconformity would exist between these two formations in East Tennessee; this was always Ulrich's belief. The writer however finds no evidence for such a disconformity in East Tennessee (p. 13). Cooper (1944, p. 27) likewise found no physical evidence for an unconformity in the Burkes Garden area of Virginia, though he realized that one was to be expected if the Brierfield dolomite really overlies equivalents of the Nolichucky shale in Alabama. If, however, the Brierfield rests on equivalents of the Rutledge limestone, it and the Ketona and Bibb are represented in East Tennessee by the Rogersville, Maryville, and Nolichucky formations and not by the Copper Ridge dolomite or an unconformity beneath it.

\section{DISTRIBUTION}

In the Mascot-Jefferson City district the Copper Ridge covers a greater area than any other formation. It is found in all three belts of outcrop (p. 7) but is most extensively developed in the nort'western or Mascot belt, particularly in the region between Jefferson City and Rutledge, where, because of its nearly horizontal position, its outcrop belt covers an area of many square miles.

The best outcrops and most complete sertions of the Copper Ridge within this area-and for that matter of the other subdivisions of the Knox group-are in the western part of the Mascot belt between Knoxville and Richland (Ada on the Maynardville 30-minute quadrangle). Here the steeply dipping beds of the group form a belt 2,000 to 3,000 feet in wid ${ }^{t} h$, and there - are good sections along almost every creek crossing the strike. The best sections are along Loves (p. 27-30), Woods, Strong, and Roseberry Creeks (all on the John Sevier quadrangle), and along Big Flat Creek on the Mascot quadrangle. Northeast of Richland the outcrop belt of the formation widens abruptly lincause of a sudden flattening of the dip, reaching a maximum width of about 8 miles in the region just north of Jefferson City and gradually narrowing nortl sast of this point to a termination about 10 miles north of Morristown. Northeast of Mascot the exposures are small, discontinuous, and less common, and most of the mapping has had to be done on the basis of small outcrops and residual materials. An excellent se tion of the Copper Ridge dolomite in the Jefferson City belt was formerly exposed on Pearce Branch in the Talbott quadrangle, but the greater part of this section is now submerged beneath Cherokee Lake.

\section{IIMITS AND THICKNESS}

The contact of the Copper Ridge with tl a Maynardville limestone member of the Nolichucky shale has been discussed (p. 13); it is commonly taken at the base of the lowest bed of coarsely crystalline ravy-bedded knotty dark dolomite, for example, unit 203 of the Thorn Hill section (Hall and Amick, 1934, p. 168) and unit 86 of the Lee Valley section (Rodgers and Kent, 1948, p. 14).

The top of the formation lies somewhore within a thick zone characterized by beds of calcareous sandstone, thin-bedded fine-grained light-colored dolomite, and, in the lower part, oolitic chert, which taken altogether forms one of the most distinctive lithologic units within the Knox group. This zone comprises the beds from unit 295 to the lower part of unit 379 of the Thorn Hill section and is about 540 feet thick. 
Cullison ${ }^{12}$ placed the top of the Copper Ridge dolomite at the base of the lowest sandstone bed in this zone (unit 295) and, mostly for convenience, used this boundary consistently in all his mapping in the Norris Reservoir area. Oder (1934, p. 492, and personal communication in the field about 1938) placed the boundary about 30 feet below the top of Hall and Amick's unit 379 , about 444 feet above Cullison's contact. He also reported the finding of Stenochilina spinifera Ulrich, a Late Cambrian trilobite, in loose chert somewhere in the upper part of this sandy zone. Later (personal communication) he was inclined to place the upper contact of the formation at about the top of unit 348, the same point selected by Hall and Amick (1934, p. 201) for their Copper Ridge-Nittany ${ }^{13}$ boundary.

The contact agreed upon at informal field conferences in the forties and used consistently by most field parties working in East Tennessee during the past 10 years is at the base of a prominent sandstone, unit 305 of the Thorn Hill section. Admittedly it is an arbitrary boundary difficult to place accurately in many localities, but its approximate position can almost always be determined with enough accuracy for the purposes of a map, such as the one in this report, by drawing it just above the appearance of the highest white siliceous oolite, which commonly crops out where exposures are good and occurs as large float blocks in the soil where mapping must be done on residual materials. (See also p. 38.)

Ulrich (1911, p. 636) stated that the Copper Ridge dolomite is 1,345 feet thick in the Thorn Hill section; Hall and Amick (1934) assigned it a thickness of 1,217 feet 3 inches (after correction); Oder (1934, p. 492) gave it 1,379 feet; and according to the limits assigned in the immediately preceding paragraphs it is only 907 feet. The discrepancies between these figures are largely apparent, for no two measurements include exactly the same set of strata. Moreover, the published sections are difficult to compare because of the monotonous repetition of varieties of dolomite through most of the sequence. Two points can be almost certainly identified in all sections, however, and when the measurements between these points are compared, the agreement is remarkably close. These points are the rather abrupt transition from dominant shale to dominant limestone about the middle of the Maynardville limestone member of the Nolichucky shale, and the first appearance of aphanitic structureless limestone near the base of the Kingsport limestone. Ulrich's original

\footnotetext{
Tallison, J. S., 1937, Geology of Norris Reservoir basin : Ms. in files of Tenn. Valley Authority.

${ }^{13}$ Hall and Amick did not recognize the presence of the Chepultepec in this section and, following the usage of the time, used "Nittany" for what is now called Longview.
}

Copper Ridge chert included all strata between these limits except for 345 feet of "lower limestone," so that his total was 1,690 feet. Hall and Amick's figure for the beds in question is 1,961 feet; Oder's is 1,975 feet. An unpublished section, measured by the writer in 1929 and originally intended for this report, agress almost exactly with Oder's figure. Ulrich's section was measured in 1905, when the exposures along the highway were not as continuous as at present, and some of his thicknesses appear to have been estimated; the other three thicknesses are in close agreement.

The thickness of the formation as now delimited is 907 feet in the Thorn Hill section. Rodgers and Kent (1948, p. 14-19), measuring the same strata at Lee Valley, obtained a figure of 925 feet. Within the Mascot-Jefferson City area, the most satisfactory ssction is that on Loves Creek at the west edge of the area; here the calculated thickness is 943 feet. The formation probably retains approximately this thickness throughout the mapped area. The Loves Creek section is given below.

Section of the Copper Ridge dolomite and Nolichucky shale exposed along the tracks of the Southern Railway in the valley of Loves Creek, at the western edge of plate 1 of this report

[Measured by Josiah Bridge, November 1937]

Section begins opposite iron post with sign "Station 1 mile" and continues in a north-northwesterly direction on eith?r side of the track to the grade crossing where the old Millertown Pike crosses the tracks, $900 \mathrm{ft}$ south of the present ovirpass. Traverse distances were measured along the rail with a tapeline, and thicknesses of most units were computed from these horizontal measurements and the average dips. Thicl-nesses of some small units were measured directly across the outcrops. All thicknesses are computed to the nearest foot.

Ordovician system :

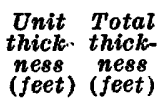

Chepultepec dolomite (Section measured in cut on east side of railroad track) :

15. Traverse distance $0-122 \mathrm{ft}$, unit distance $122 \mathrm{ft}$. Strike $65^{\circ}$, average dip $45^{\circ}$, bearing $155^{\circ}$; thickness calculated.

Dolomite, with many arenaceous layers and some distinctive chert beds. The dolomite is very poorly exposed, the interval being largely covered with residual materials-chiefly blocks of brown sandstone, derived from the weathering of arenaceous dolomite beds, and of chert. Certain layers of sandstone and chert are still approximately in place and show the general structure. A
$85 \quad 85$ 
Ordovician system-Continued

Chepultepec dolomite - Continued conspicuous bed of white siliceous oolite about $1 \mathrm{ft}$ thick crops out about $32 \mathrm{ft}$ stratigraphically ( $45 \mathrm{ft}$ horizontally) below the top of the section; above it are some layers of white compact platy chert containing long, narrow, oblong slots arranged parallel to the bedding: these are believed to be the molds of flat limestone pebbles that have been dissolved. A thin bed of sandstone crops out about $1 \mathrm{ft}$ below the oolite bed; 23 ft stratigraphically (33 ft horizontally) beneath this is a second bed of soft rusty brown sandstone about $2 \mathrm{ft}$ thick. The base of the unit consists of about $8 \mathrm{ft}$ of mediumgrained sandstone, soft, friable, and porous at the top, becoming harder and more quartzitic toward the base. This sandstone is commonly stained rusty brown but freshly broken surfaces are white.

Cambrian system :

Copper Ridge dolomite:

14. Traverse distance $122 \mathrm{ft}$ to $245 \mathrm{ft}$, unit distance $123 \mathrm{ft}$. Strike $65^{\circ}$, average dip $53^{\circ}$, bearing $155^{\circ}$; thickness calculated

Dolomite, with arenaceous layers, weathering to sandstones, the exposure in the railroad cut being made up largely of ledges of dolomite exposed in the creek bed to the west. Stratigraphically $44 \mathrm{ft}$ below the top of the unit is a zone of oolitic chert about $2 \mathrm{ft}$ thick, and $52 \mathrm{ft}$ stratigraphically below this are 2 thin beds of oolitic chert from 1 to 4 in. thick. These beds are $180 \mathrm{ft}$ and $243 \mathrm{ft}$, respectively, north of the initial point (horizontal measurement) and are believed to correspond to the oolites in units 304 and 282, respectively, of the Thorn Hill section (Hall and Amick, 1934, p. 198199). Both oolite beds are exposed in the bed of Loves Creek a few tens of feet west of the railroad. Beneath the lower oolite is about $2 \mathrm{ft}$ of soft porous brown sandstone.

13. Traverse distance 245 to $693 \mathrm{ft}$, unit distance $448 \mathrm{ft}$. Strike $65^{\circ}$, average dip $57^{\circ}$, bearing $155^{\circ}$; thickness calculated.
Unit Tota.

(feet) (feet)

Cambrian system-Continued

Copper Ridge dolomite-Continued

Dolomite, light-steel-gray with a few scattered layers that are dark gray to chocolate brown. Bedding distinct, zones with beds 1 to 3 in. thick alternating with zones in which the individual layers are from 5 to 8 in. thick. Texture compact and very fine grained, more fine grained than in unit 12. Weathered surfaces light gre. $y$, lighter than those in unit 12 , often streaked with shades of $t$ in and buff. Several horizons of chert in beds as much as 4 in. thick. Chert is commonly hon?y colored, compact, with a waxy texture and splintery fracture. Joints normal to bedding, w?ll developed and closely spaced.

12. Traverse distance, 693 to $770 \mathrm{ft}$, unit distance $77 \mathrm{ft}$. Strike $65^{\circ}$, dip $60^{\circ}$, bearing $155^{\circ}$; thickness calculated

Dolomite, medium-gray to brownish-gray; darker than in unit 13, much lighter than in unit 11; beds commonly 10 in. or more thick, bedding planes indistinct, somewhat wavy and minutely irregular. Fracture sharp and clean, but not conchoidal. Weathered surfaces smooth to granular (sandpaper texture), dark gray with tan and buff stains. Bers cut by widely spaced vertical joints belonging to two systems. Between traverse distances $\mathbf{7 1 5}$ ft and $747 \mathrm{ft}$ is a zone about $28 \mathrm{ft}$ thick composed largely of resirual chert with a few scattered outcrops of dolomite. The chert is platy and occurs in layers as much as 3 in. thick. It is block and semitranslucent when fresh but weathers to light-gray or cream-colored somewhat tripolitic chert. Surfaces are commonly stained by oxides of iron and manganese, and the fracture is hackly or splintery. Associated with the chert are beds of silicified cryptozoa irregular in outline because of crowding; the individual heads, which are as mvoh as 6 in. across, are grouped into confluent masses 2 ft or more across.
Unit Total

thick- thick-

$\begin{array}{cc}\text { ness } & \text { ness } \\ \text { (feet) } & \text { (feet) }\end{array}$ (feet) 
Cambrian system-Continued

Copper Ridge dolomite-Continued

11. Traverse distance $770 \mathrm{ft}$ to $895 \mathrm{ft}$, unit distance $125 \mathrm{ft}$. Strike and dip as in unit 12 ; thickness calculated.

Dolomite, dark-gray, brown, and chocolate-brown, finely to medium crystalline; individual layers 10 in. to $2 \mathrm{ft}$ thick, little or no sign of laminations, major bedding planes indistinct, somewhat wavy, minutely irregular. Fracture sharp and clean. Weathered surfaces dark gray but lighter than freshly broken surfaces, often stained with buff and tan shades, smooth to minutely granular. Beds cut by at least two systems of widely spaced vertical joints. Chert is present at various levels as irregularly laminated roughly tabular masses parallel to the bedding planes. Most of it was originally dark gray to black, but some of the masses are white. All of it weathers to a dead chalky white, the surfaces usually stained by oxides of iron and manganese. It breaks into small rectangular blocks and splinters with sharp edges. (The railroad cut ends 840 ft north of the initial point in the middle of this unit, and, from here north, the section is compiled from outcrops in the creekbed and in the fields and road cuts on either side of the track.)

10. Traverse distance 895 to $1,225 \mathrm{ft}$. unit distance $330 \mathrm{ft}$. Strike and dip as in units 11 and 12 ; thickness calculated

Dolomite, mostly light gray with some dark beds as in unit 11 . Beds commonly 1 to $3 \mathrm{ft}$ thick; lower beds poorly exposed. The base of this unit and the base of the Copper Ridge dolomite are about $140 \mathrm{ft}$ south of the point where the road to Spring Park Church crosses the railroad.

Nolichucky shale:

Maynardville limestone member:

9. Traverse distance 1,225 to $1,295 \mathrm{ft}$, unit distance $70 \mathrm{ft}$. Strike $65^{\circ}$, dip $63^{\circ}$, bearing $155^{\circ}$; thickness calculated

Limestone, somewhat dolomitic, aphanitic to very finely crystal-

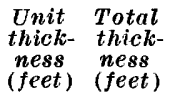

$\begin{array}{ll}\text { (feet) } & \text { (feet) }\end{array}$
Cambrian system-Continued

Nolichucky shale - Continued

Maynardville limestone member-Con. line. Thin bedded, commonly with many alternations of limestone and dolomite layers. Mostly light steel gray with a few thin shale partings. The lower $15 \mathrm{ft}$ more thickly bedded and more strongly dolomitic.

8. Traverse distance 1,295 to $1,489 \mathrm{ft}$, unit distance $194 \mathrm{ft}$. Strike and dip presumably as above; thickness calculated

Covered interval, a few scattered outcrops of limestone. (Road to church crosses railroad $1,439 \mathrm{ft}$ north of initial point.)

7. Traverse distance 1,489 to $1,565 \mathrm{ft}$, unit distance $76 \mathrm{ft}$. Strike $65^{\circ}$, dip $63^{\circ}$, bearing $155^{\circ}$; thickness calculated

Limestone, fine-grained to aphanitic, blue to bluish-gray, with thin nodules and seams of dolomitic and clayey material parallel to the bedding planes. These magnesian layers weather dark and stand out in relief, giving the outcrops a characteristic mottled and ribboned appearance. Beds 1 to $3 \mathrm{ft}$ thick in fresh exposures but breaking down into thin plates 1 to 5 in. thick on further weathering. This sequence is well exposed in the fields west of the road opposite Spring Place Church and in the creekbed between the road and the railroad.

Lower shale member :

6. Traverse distance 1,565 to $1,875 \mathrm{ft}$, unit distance $310 \mathrm{ft}$. Strike $65^{\circ}$. dip assumed to be $65^{\circ}$, bearing $155^{\circ}$; thickness calculated Shale, soft, thin-bedded, olivegreen; the interval mostly covered, best exposures toward the base. (At traverse distance, 1,875 ft the section appears to be broken by a small strike fault (not shown on the map), which is probably a sliver of the main Saltville thrust, and which repeats the upper part of the lower shale member of the Nolichucky shale and the Maynardville limestone member. This fault was not recognized when the section was measured and has not been traced laterally along the strike.)
Unit Total thici- thick$\begin{array}{cc}\text { ness } & \text { ness } \\ (\text { fee } & \text { (feet) }\end{array}$ 
Cambrian system-Continued

Nolichucky shale-Continued

Maynardville limestone member:

5. Traverse distance 1,875 to $2,075 \mathrm{ft}$, unit distance $200 \mathrm{ft}$. Strike $70^{\circ}$, dip averaging $70^{\circ}$, bearing $160^{\circ}$; thickness calculated.

Limestone, fine-grained to aphanitic, blue, with patches and thin layers of coarser grained lighter colored dolomitic material; similar to and probably a repetition by faulting of the beds in units 7 and 8.

Lower shale member:

4. Traverse distance 2,075 to $2,295 \mathrm{ft}$, unit distance $220 \mathrm{ft}$. Strike and dip as in unit 5 ; thickness calculated

Largely covered, but with a few outcrops of soft olive-green shale, similar to unit 6 .

3. Traverse distance 2,295 to $2,345 \mathrm{ft}$, unit distance $50 \mathrm{ft}$. Strike and dip as in unit 5 ; calculated thickness

Partly covered, but with several small outcrops of soft olive-green shale, similar to unit 4.

2. Traverse distance, 2,345 to $2,720 \mathrm{ft}$, unit distance $375 \mathrm{ft}$. Strike and dip as in unit 5; thickness calculated

Shale, olive-green to greenishgray, soft, well-bedded; well exposed in low railroad cut.

1. Traverse distance 2,720 to $3,095 \mathrm{ft}$, unit distance $375 \mathrm{ft}$. Strike and dip as above; thickness calculated

Shale, similar to unit 2 , not continuously exposed but with many exposure in low cuts on the east side of the Loves Creek road. Base not exposed but somewhere near the grade crossing of the old Millertown road and the railway.

Total lower shale unit, units 1 to 4

Total Maynardville limestone member, units $\overline{7}$ to 9

Total Nolichucky shale

There are many but discontinuous exposures of the older Cambrian formations along the railroad track and in cuts along the roads parallel to it from this point north to the trace of the Saltville fault that crosses the railway about 6,000 feet north of the initial point. The Maryville limestone is represented by a band of red soil about 400 feet wide, which, assuming a dip of $65^{\circ}$, would indicate a thickness of about 360 feet. The Rogersville shale is well exposed in the cuts at the overpass, where the present Millertown road crosses the railroad. Just north of this is a zone of limestone about 280 feet wide, representing a stratigraphic interval of about 255 feet. This zone seems to be the thinned remnant of the Rutledge limestone.

North of the base of this limestone unit, the shales of the upper part of the Rome formation (Pumpkin Valley shale of Rodgers and Kent, 1948) are rather complexly folded, dipping both southeast and northwest, and are cut by one or more small strile faults so that it is difficult to obtain an accurate estimate of their thickness. The shales here are now being quarried and expanded into lightweight aggregate.

\section{BEDROCK IITHOLOGY}

The most distinctive rock type of the Conper Ridge dolomite is a dark, medium to coarsely crystclline thickbedded dolomite. Freshly broken surfaces of this rock give off a strong fetid odor, which is one of the most characteristic aids in the recognition of the formation. A similar odor can be detected in fracturec rock from few beds in other formations in the section, and even in these the odor is rarely as strong as that from characteristic dark dolomite of the Copper Ridge.

The fracture is rough and hackly, and freshly broken surfaces are dark purplish gray to reddich or brownish gray. This dark color is also a distinctive characteristic. The texture appears sugary, and th a rock commonly shows many small veinlets and kncts of white dolomite or quartz. Beds are commonly from 12 to 24 inches thick. The principal bedding planes are essentially parallel, but their surfaces are irregularly knobbed and pitted, these minor features having a relief of an inch or less. Minor bedding planes are faint or invisible. Jointing is well developed, but the individual joint planes are commonly rather widely spaced. Weathering accentuates the joint and major bedding: planes and causes the outcrops to break into large blocks with rounded edges, more rarely into a mass of pinnacles.

Weathered surfaces are commonly dull lead gray, which however is of a lighter shade than the color of the fresh surfaces.

This dark odoriferous crystalline knotty dolomite is the most distinctive lithologic type found in the Copper Ridge dolomite, but normally it is interbadded with fine-grained light-steel-gray dolomite of a trpe common throughout the Knox group. The dark dolomite is confined to the lower two-thirds or three-fourths of the formation and is one of the best means of identifying the formation in fresh exposures. This criterion must be used with a certain amount of caution, lowever, for 
this lithologic type, together with its characteristic odor, reappears as single beds, or in short sections composed of several beds, at several levels through the Ordovician part of the Knox group. The most conspicuous recurrence of this type is found in a zone about 20 feet thick near the top of the Mascot dolomite.

The lithology of the upper part of the Copper Ridga dolomite is quite different from that of the lower part. The strata are mainly medium- to thin-bedded commonly laminated fine-grained to aphanitic light-gray to bluish-gray dolomite, similar in many respects to the dolomite in the upper part of the Maynardville limestone member and also to much of the dolomite found in the Ordovician formations of the Knox group. The distinctive lithologic features of this part of the formation are not found in these widely distributed rather nondescript rocks, but rather in the layers of chert, siliceous oolite, and calcareous sandstones that are interbedded with them. Many of these special lithologic types also persist into the overlying formations, and, as a general rule, it is the combination of several factors, rather than any single one, that is relied upon in making final identifications.

\section{RESIDUAL PRODUCTS}

The principal residual products of the Copper Ridge dolomite are clay, chert, and sandstone.

The clays are heavy, brittle when dry, sticky and tenacious when wet, and commonly orange to brick red where little or no soil is present. 'Soils developed on these clays are much lighter in color, gray and grayishbrown tints predominating.

Chert of various types, the greater part of it derived from the selective silicification of the dolomite during weathering, is extraordinarily abundant in the clay and soils of most areas underlain by the Copper Ridge dolomite. On the contrary, beds and layers of chert are not common in fresh exposures; many of those that are found seem to be replacements of structures that were originally deposited as limestone, that is, siliceous colites and silicified algal lime secretions (cryptozoa).

Layers of flat ovoid compact chert nodules arranged along bedding planes, such as are common in the Chepultepec and younger formations of the Knox group and could be regarded as syngenetic, are not conspicuously developed in the Copper Ridge. The dolomites of the formation contain much interstitial colloidal silica, invisible in hard samples but appearing as a characteristic insoluble residue when fragments of the dolomite are dissolved in hydrochloric acid. The writer believes that during the process of weathering this colloidal silica goes into solution and is redistributed and concentrated as chert on exposed surfaces, and that this process accounts for most of the surficial chert.
The silicified layers found not only in outcrops but also in drill holes and mine workings in all probability represent replacement of layers along which the movement of ground water was especially active.

The bulk of the residual chert from the Copper Ridge dolomite is dull and opaque, grayish white, with the surfaces commonly stained various shades of yellow, red, and black by the oxides of iron and manganese. It is mostly compact and even textured, finely grarular to aphanitic, and free from large cavities. On further weathering, it breaks down into smaller and smaller rectangular blocks and splinters.

In wooded areas where the soil has been undisturbed for years and where the ground cover of vegetation is sparse, the surface of areas underlain by the Conper Ridge dolomite is commonly covered by a pavement of small angular light-colored chert fragments, with very few large blocks of chert. Chert-covered slopes of this type are a rather reliable index to the underlying formation. Areas that have been cultivated seldom show this pavement, but on the other hand they show a nuch larger proportion of large chert blocks.

Another variety common in the lower part of the formation and rather characteristic of it is black semitranslucent chert in irregular masses, commonly stained a dull red on weathered faces but breaking with a conchoidal fracture and lacking the regular jointing of the other varieties. These black cherts are particuJarly abundant in the zone of the dark dolomites.

Oolitic cherts are found throughout the formations of the Knox group, but they are especially numerous and distinctive in the residual chert of the Copper Ridge dolomite. Several varieties are distinguishable, and because they can be recognized in drill cuttings and mine workings (Oder and Miller, 1945, p. 9; Allen, 1?48), they are extremely useful for correlation. About 33 feet above the base of the formation is a bed of oolitic dolomite, commonly silicified, which is a rather conspicuous marker (Oder, 1934, p. 477; Hall and Amick 1934, p. 195, unit 214). The ooids in this bed average $11 / 2$ millimeters in diameter and commonly are strikingly color banded. Except for the oolite in the $\mathbb{N}^{x}$ aynardville limestone member (p.12,18), this is the lowest bed of siliceous oolite known in the area. Other beds of siliceous oolite are found throughout the Copper Ridge dolomite, but they are most concentrated in the upper zone of light-colored dolomite. Some of the more conspicuous of these oolite beds in this zone are mentioned by Hall and Amick (1934, p. 197-199, units 271, 282, 302 ), but the most persistent and widely recognized one is the oolite bed in unit 304 of this section which they list as "an 18-inch chert bed." This bed is 27 feet below the top of the Copper Ridge dolomite as here delimited 
and, together with the bed 39 feet below it in unit 302, has been recognized in so many parts of East Tennessee that the two beds are commonly used as a guide to the top of the Copper Ridge dolomite. Beds of siliceous oolite believed to be equivalent to the beds at Thorn Hill have been recognized in the Lee Valley section (Rodgers and Kent, 1948, p. 17-19, units 132, 148, 157, 161), where the intervals between the two upper beds and between the uppermost bed and the top of the formation are 43 and 29 feet, respectively. This close agreement between the two sections some 16 miles apart emphasizes the persistence of small distinctive lithologic units and the importance of their recognition and use in correlation, a fact long recognized and used by Ulrich and repeatedly stressed by him.

Within the Mascot-Jefferson City area two beds of siliceous oolite-believed to be the same as those just mentioned-have been found in many places. In the Loves Creek section the two beds are 44 feet apart, a figure that is very close to the distance between the two beds in the Thorn Hill and Lee Valley sections. In the Loves Creek section, however, the uppermost bed is 48 feet below the heavy sandstone taken as the base of the Chepultepec dolomite. The greater thickness in this locality may be due to a local thickening of the Copper Ridge dolomite, or it may be due to a miscorrelation between the sandstones in the Copper Ridge belt and the ones in the Loves Creek section. It could also be due to local erosion of the upper beds of the Copper Ridge dolomite on Copper Ridge.

All these siliceous oolites are conspicuously color banded, and this, together with the comparatively large size of the individual ooids, distinguishes them from the smaller uniformly colored oolites of the younger formations of the Knox group.

Another common and distinctive variety of chert is made up of silicified masses of supposed lime-secreting algae, commonly and collectively known as cryptozoa. At some localities, notably in certain beds in the Thorn Fill section and also in the small abandoned quarry at the north end of the bridge across Holston River on State Highway 92 just west of Cherokee Dam, these structures are preserved in dolomite beds, thus indicating that the silicification so common in other layers and in residual materials is secondary. Thin sections, both of the dolomitic and siliceous varieties, have not shown any traces of plant structure, and because of this some have argued that the so-called cryptozoa are not fossils but merely inorganic structures. Opposed to this purely negative evidence are the facts that they occur at definite stratigraphic levels in certain formations, that certain broadly generalized types are restricted to certain stratigraphic levels, and that they have wide, though not universal, distribution at such levels and appear to be reefs or bioherms. They are conmmnly grouped under the generic designation Cryptozoon and a number of "genera" and "species" have been described. Their habits of growth are variable, however, and commonly one type passes into another by almost imperceptible gradations. The distance between the individual pillars of a colony, the diameter of these columns, and their relative spacing do not seem to be specific characters, although attempts hrve been made to use them as such. In this report about all that can be done is to class cryptozoans as solitary or colonial.

Several varieties of each of these troo classes are known at various levels in the Knox gro'p, but two of them are abundant and practically restricted to the Copper Ridge dolomite. One type, belonging to the solitary class, consists of circular or cup-shaped masses of chert ranging from 4 or 5 inches to more than a foot in diameter, the mass consisting of thin parallel plates concentrically arranged around a common center of attachment on the basal side. They resemble thickwalled shallow saucers and commonly oc?ur as isolated individuals distributed along certain badding planes but locally as loose colonies.

A second and more common type is the colonial variety that consists of a series of cores or pillars spaced from 1 to 2 inches to a foot or more apart. Each pillar is formed by a series of thin laminae convex upward. Where the pillars are widely spaced the cryptozoans have a superficial resemblance to cabbag? heads in longitudinal section; where they are tightly crowded they give the impression of closely contorted laminae in cross section and the surfaces of the laminae themselves exhibit a distinctive "waffle-iron" pattern of knobs and furrows. Entire layers 2 feet or more thick in the lower part of the Copper Ridge dolomite may be made up of this form and locally seroral such layers may be grouped together in a ratl or thick zone (Hall and Amick, 1934, units 226-232, p. 195-196). This small waffle-iron form is very common in the lower part of the Copper Ridge dolomite and was for many years believed to be restricted to that horizon. Recently, however, Cattermole (personal communication, 1949) has found quite similar cryftozoans in the Mascot dolomite. The colonies appear to be much smaller, seldom more than a foot in diameter, and are not so numerous or so widely distributed as in the Copper Ridge dolomite, so that abundant cryptozoans of this type are an almost certain indication of the Copper Ridge dolomite. One variety of this small colonial form has been described as Cryptozonn undulatum Bassler. It is well exposed in the small quarry at the north end of the bridge across Holston River near 
Cherokee Dam. Chert derived from beds of these cryptozoans is abundant on the hills just south of U. S. Highway $11-W$ about 0.75 mile north of Three Points on the John Sevier quadrangle and at many other localities both within and beyond the Mascot-Jefferson City district. A variety of this form in which the columns are more widely spaced is exposed in the bed of Buffalo Creek about 0.2 mile north of the road fork at BM 1057 on the Joppa quadrangle.

The large solitary saucer-shaped type is less common but it is also widely distributed. It has been seen in place in the Thorn Hill section, and at one time there was an excellent exposure weathered out along - the county road just east of Mascot on the Mascot quadrangle, about 0.25 mile south of the crossing of Roseberry Creek at BM 903.

All these forms are highly characteristic of the Copper Ridge dolomite, and their abundance in residual materials is of great value in mapping.

Many dolomitic layers in the upper part of the Copper Ridge dolomite are highly arenaceous and when weathered appear both on the outcrop and in residual accumulations as soft, porous brown sandstone. Locally, these sandstones are recemented by silica and thus become hard, impervious, and quartzitic. Beds of this material also occur in the base of the overlying Chepultepec dolomite and with the beds in the upper Copper Ridge mark one of the most distinctive zones in the Knox group. Other thin beds of arenaceous dolomite occur at higher levels and some of these are important key beds, but nowhere in the Knox group is the concentration of sandy layers as great as near the Copper Ridge-Chepultepec boundary.

\section{SUBDIVISIONS}

The Copper Ridge dolomite could be logically divided into two members: a thick lower member composed mainly of dark thick-bedded cherty dolomite, and an upper member consisting of light-colored thinner bedded dolomite, also chert-bearing and containing many arenaceous beds. If such a subdivision were made, the break would come within unit 282 in the Thorn Hill section and at the base of unit 148 in the Lee Valley section (Rodgers and Kent, 1948, p. 14). This upper member is about 228 to 235 feet thick along Copper Ridge, and, although it has not been named, it has been separately mapped there (Rodgers, 1943).

Oder (1934, p. 476-479) also divided the Copper Ridge dolomite into two members, calling them the Morristown dolomite and the Bloomingdale limestone members. He assigned a thickness of 800 to 1,000 feet to the Morristown dolomite member and included in it all strata from the top of the Maynardville limestone member up to and including some of the arenaceous layers. Thus his Morristown member seems to correspond approximately to the entire Copper Ridge dolomite as here delimited. The Bloomingdale limertone member was said to range from 170 to 650 feet in thickness in various parts of the Valley of East Tennessee, though no explanation of these variations in thiclness was given. It is now thought that most of the strata placed in the Bloomingdale member by Oder belong in the lower part of the Chepultepec dolomite as now recognized.

\section{FACIES RELATIONSHIPS}

The Copper Ridge is a dolomite in the type area, and this dolomitic phase extends along the western side of the Appalachian Valley in East Tennessee and southeastward into and across the Mascot-Jefferson City district. To the southeast of this area, however, beds of limestone wedge into the section, and on the eastern side of the Valley, particularly in the belts southeast of the Bays Mountain syncline (pl. 2), the entire fc rmation is dominantly a slightly magnesian limestone. This limestone extends northeastward along the eastern side of the Valley into Virginia, and in the central and northern parts of that State it extends prcorressively into the western belts as well, until in northern Virginia, Maryland, and southern Pennsylvania the limestone phase extends almost entirely across the Valley, though not into the western ridges of the Appalachians.

This limestone facies is commonly known as the Conococheague limestone, from Conococheague C reek, Franklin County, Pa. (Stose, 1908, p. 701-703), and the name has been extended into Virginia ( $\mathrm{W}^{\top} \mathrm{ood}-$ ward, 1932, p. 37; Butts, 1933, p. 8-9) and Tenrossee (Oder, 1934). Ulrich recognized the presence of the Conococheague limestone in these areas but contended that it was older than the Copper Ridge dolomite, and that it thinned westward and was overlapped unconformably by the Copper Ridge. For a while Butt: also maintained this view, but later as a result of detailed mapping he realized that the two formations were intergrading facies equivalents (Woodward, 1932, F. 37; Butts, $1940 \mathrm{~b}$, p. 90). This has been demonstrated at several places, and the correlation is strongly supported by paleontologic evidence.

Still farther north in central Pennsylvania, the Conococheague limestone seems to grade northwestward into a sandy magnesian limestone facies, the Gatesburr formation (Butts and Moore, 1936, p. 15-17; Butts, 1939, p. $10-12 ; 1945$, p. $2-3)$. The Gatesburg formation together with the overlying Mines dolomite (same reference) occupy about the same stratigraphic inter"al as the Conococheague limestone a few miles to the south- 
east. Resser (1938, p. 20) correlated the Mines and Gatesburg with the Conococheague, without, however, clearly stating his reasons. Still later (Howell and others, 1944), Resser made the Mines dolomite an upper member of the Gatesburg formation, assigned two wellknown Upper Cambrian faunal subzones to it, and again correlated his enlarged Gatesburg formation with the Conococheague, without giving definite reasons.

More recently Wilson (1949), in discussing this same general area, writes that "A general facies change west to east from arenaceous dolomite (Gatesburg formation) to silt-laminated limestone (Conococheague formation) is indicated in the geosyncline." This statement, based as it is on detailod field studies, strongly supports the idea of facies equivalence here advocated. Wilson says nothing about the relation of the Mines dolomite to this problem, but such evidence as is available indicates that Resser's assumption is logical and probably correct. This point is discussed in more detail below.

\section{PALEONTOLOGY AND CORRELATION}

No fossils, aside from cryptozoa, have been found in the Copper Ridge dolomite within the limits of the Mascot-Jefferson City district, and, although a few fossils have been found at widely separated localities throughout the Appalachian Valley, the formation is nowhere abundantly fossiliferous. This scarcity of well-preserved and identifiable fossils has been one of the most serious drawbacks in regional correlation, for many of the supposedly equivalent formations in other parts of the United States carry well-preserved and abundant fossils at many horizons. From the evidence now available the writer believes that the Copper Ridge and Conococheague formations of East Tennessee may be correlated almost exactly with the Madison, Trempealeau, and Franconia formations of the Upper Cambrian section in the upper Mississippi Valley and their equivalents elsewhere. Some of these correlations are based on the presence of identifiable fossils, whereas others are merely inferred from similarity of stratigraphic position.

In his original description of the formation, Ulrich $(1911$, p. 636), says :

So far as the collections go, they indicate at least two fossiliferous horizons, both apparently near the middle of the Copper Ridge formation. Aside from this, their stratigraphic relations are unknown. One contains Syntrophia campbelli and fragments of so-called Cambrian trilobites, the other gastropods and cephalopods found in the Eminence formation of Missouri. The same or a close ally of the Syntrophia, also trilobites of very similar character to those associated with it in Tennessee, are found in Shannon County, Missouri, in the same formation (Fminence) above the gastropods. If these faunal occurrences are trustworthy indications of one and the same stratigraphic zone, then a considerable hiatus is suggested in the Missonri section between the Eminence and Potosi formations.

It is now known that the Syntrophia campbelli fauna does not occur in the Copper Ridge dolomite but is confined to the upper part of the Chepultepec and the lower part of the Longview dolomites and to similar parts of equivalent formations elsewhere (see p. 43,49).

The gastropod-cephalopod fauna mentioned by U1rich does occur in the Eminence dolomite of Missouri, but the forms that Ulrich had in mind at the time he made that statement are now known to have come from the lower beds of the Van Buren member of the Gasconade dolomite (Bridge, 1930, p. 106-10尺). The statement that "several of the Van Buren species, and several others which are closely allied hare been found in the Copper Ridge dolomite in Alabama" (Bridge, 1930, p. 108) is an error resulting from this miscorrelation (see p. 36 ).

Oder $(1934$, p. 478,493$)$ discovered the trilobite Stenochilina spinifera Ulrich in float chert in the sandstone zone at the top of the Copper Ridge dolomite in the Thorn Hill section (p. 27). The exact layer is not known, and a careful search has yielded no additional specimens. From Oder's description it is entirely possible that the specimen came from bers that are included in the Chepultepec dolomite in this report. $\mathrm{He}$ also collected Calvinella cf. $C$. ozarkensis (Walcott) and $C$. minor Ulrich near the top of the formation at an unspecified locality in Greene County. These are all high Upper Cambrian forms, characteristic of the upper part of the Eminence dolomite of Missouri anc of the Jordan and Madison sandstones of Wisconsin.

In 1911 Ulrich and Kirk made an extensive collection of trilobites in thin-bedded platy black conglomeratic chert associated with a very fine grained black limestone and thin sandstone beds along the old Knoxville Pike (now approximately U. S. Highway 11-E) about 1 mile west of the railroad station at Gre?neville, Tenn. The trilobites, which are rather poorly preserved, all seem to belong to a single species, Plethopeltis saratogensis (Walcott), a species originally described from the Hoyt limestone of the Saratoga region in New York. The genus is also found in the Eminen?e dolomite of Missouri and in the Madison sandstone of Wisconsin. Its age is late Late Cambrian, and the level occupied by these fossils is approximately the same as the one carrying Stenochilina at Thorn Hill.

Ulrich provisionally referred the beds carrying this fauna to a new formation, the Greenerille limestone, and, according to his notes, the collection came from a horizon between 1,450 and 1,463 feet above the top of the Nolichucky shale. By this he meant the top of the lower shale unit as herein descriked. Thus the 
Greeneville limestone of Ulrich included not only the entire Copper Ridge dolomite or Conococheague limestone but also the Maynardville limestone member of the Nolichucky shale (chart 1).

Ulrich never published any description of his Greeneville limestone or of this fauna. In 1924, however, Nelson published two correlation tables (Gordon, 1924, p. 34; Secrist, 1924, p. 16) representing his interpretation of Ulrich's views. In these the Greenville [sic] dolomite was placed beneath the Copper Ridge dolomite and was credited with a thickness of 400 feet. Thus the Greenville dolomite of Nelson seems to be almost the exact correlative of the Maynardville limestone member of this report.

James L. Wilson (written communication, March 3, 1950) reports finding a specimen of Plethometopus(?) sp. somewhere in the upper 550 feet of the Conococheague limestone on the northwest side of the Mosheim dome just north of Big Spring Church, Mosheim quadrangle. This is about 7 miles west-northwest of the localities at Greeneville. These 4 localities are the only ones known to the writer from which trilobites have been collected in the upper part of the Conococheague or Copper Ridge formations of East Tennessee. In Virginia the trilobite Tellerina wardi (Walcott) has. been reported from at least 2 localities (Resser, 1938, p. 14, 16, 22, 24, 101; Butts, 1940b, p. 89) where it seems to occur in a thin zone about 150 feet below the top of the formation. Another species of Tellerina is reported from near Scotland, Pa., where it is associated with Saukiu stosei (Walcott). Wilson (ibid.) lists several trilobite genera from a locality about 1 mile northeast of Stonehenge, Pa., on the Chambersburg quadrangle. The exact stratigraphic level is not known but is believed to be near the top of the formation. These genera-Prosaulia, Plethometopus, Stenopilus, Bowmania, and Leiocoryphe-all occur in the upper part of the Upper Cambrian, more specifically in the upper part of the Trempealeau formation and in the Madison sandstone of Wisconsin, in the Eminence dolomite of Missouri, in the San Saba member of the Wilberns formation of Texas, and in equivalent strata elsewhere in the United States. These trilobites in the Copper Ridge and Conococheague formations in the Appalachian Valley serve to correlate the upper part of these formations with uppermost Upper Cambrian formations in other parts of the United States.

A second faunal zone is found about 550 to 600 feet below the top of the formation as here drawn. The dominant forms in this assemblage are species of Scaevogyra, a form which is easily recognizable because it is the only large gastropod in any of the formations of the Knox group that is coiled sinistrally. This fauna has been found at many localities in the Norris Reservoir area, ${ }^{14}$ commonly in residual cherts but locally from chert beds in place. At a locality in the LaFollette quadrangle, now submerged by the Norris Reservoir, it is associated with specimens of Plethometopus.

The Scaevogyra fauna has not been found in the Thorn Hill or Lee Valley sections nor within the Mascot-Jefferson City district, but it has been found at other localities in the Valley of East Tennessee to the south and southwest of the district. Presumably it occurs within the district, and more careful study and collecting should reveal its presence. It was or: ginally found in the southern Appalachian Valley by Butts $(1926$, p. 87 , pl. $14 ; 1927$, p. $4 ; 1940$ a, p. 7 ) at three widely separated localities, all east and soutr oast of Birmingham, and it is the gastropod-cephalopot fauna mentioned in Ulrich's original description of the formation. The list of species, in which the names hrve been revised to conform with current usage, is given below :

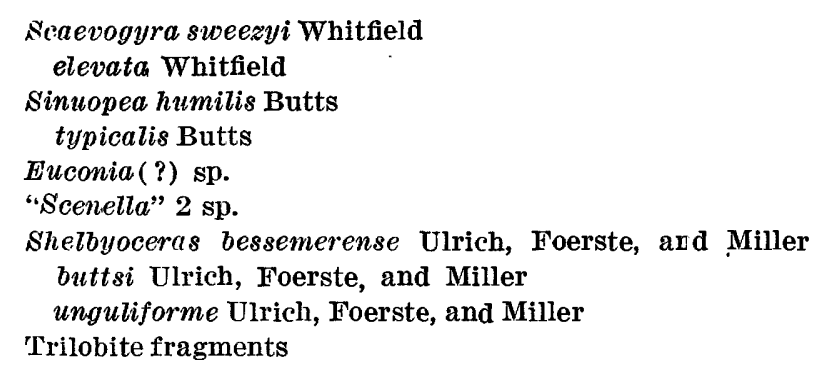

Elements of this fauna have also been found by Cloud (oral communication) in northeastern Alabama. From the above it would seem that the Scaevogyra fauna is widely distributed throughout the southern part of the Appalachian Valley, and that it is an important and useful faunal horizon.

Scaevogyra sweezyi was originally described from the St. Lawrence member of the Trempealeau formation of Wisconsin. It has subsequently been found in the upper part of the Potosi dolomite of Missouri, where it is associated with Shelbyoceras bessemerense Ulrich, Foerste, and Miller (Bridge, 1930, p. 208; Ulrich, Foerste, and Miller, 1943, p. 153), and in the lover part of the Eminence dolomite in the same area. Finally, it occurs in the Pedernales dolomite member of the Wilberns formation in central Texas (Dake and Bridge, 1932, p. 730, pl. 12; Bridge, Barnes, and Clouf, 1947, p. 122, 123). In all three States Scaevogyra is commonly associated with Platycolpus and in Missciri and Texas with Plethometopus also. It is possible trat some of the trilobite fragments in the collections made by Butts belong to these genera.

14 Cullison, J. S., 1937, Geology of Norris Reservoir basin : Ms. in files of Tenn. Valley Authority. 
Shelbyoceras, the oldest true cephalopod genus known in North America (Ulrich, Foerste, and Miller, 1943, p. 152-155), occurs sparingly in the Eminence and Potosi dolomites of Missouri-always in association with one or more of the other genera in the foregoing list-and seems to be restricted to Upper Cambrian rocks.

Sinuopea is a long-ranging genus, common in both Upper Cambrian and Lower Ordovician strata. It is a highly generalized form in which species are drawn on minute differences. These differences are seldom well-enough preserved for exact identification, and, because of this, the genus is of little use in exact correlation.

The other forms listed are too imperfectly known to be of much value.

It was elements of this fauna, particularly Sinuopea and Shelbyoceras, that Ulrich had in mind when he correlated the Copper Ridge fauna with the gastropodcephalopod fauna of the Eminence (Ulrich, 1911, p. 636). This "Eminence fauna" of Ulrich was subsequently found to occur actually in the base of the overlying Gasconade dolomite, the Van Buren formation of McQueen (1931) and of Bridge (1930, p. $98 \mathrm{ff}$.). This in turn explains Bridge's miscorrelation of the Copper Ridge and Van Buren formations (Bridge, 1930 , p. 108,208 ), a correlation that was repeated by Butts and Moore (1936, p. 18-19), and by others (Butts, 1939, p. 13; Ulrich, Foerste, Miller, and others, 1943, p. 2,$11 ; 1944$, p. 15). Actually the studies of Ulrich, Foerste, and Miller have shown that the cephalopods of the Copper Ridge dolomite in Alabama, formerly referred to such genera as Levisoceras, Quebecoceras, and Ectenoceras, all belong to the genus Shelbyoceras, and that this last form, so far as now known, is confined to the Copper Ridge, Eminence, and Potosi dolomites.

Because of its distinctive character and wide distribution, the Scaevogyra zone has been widely used in regional correlation (Howell and others, 1944, p. 994, chart), and its presence in the Copper Ridge dolonite indicates definitely that the lower part of the Trempealeau formation is also represented here.

Another form which may eventually become an important fossil for the Copper Ridge dolomite is the rather large planispiral gastropod Cloudia buttsi Knight $(1947$, p. 6-7, pl. 2). This species is known only from a rather large number of localities in central and northeastern Alabama and northeastern Georgia, but in all probability its geographic range will be extended with the progress of detailed mapping. It invariably occurs "just above a zone of digital Gymnosolen-like stromatolites in splotchy black-and-white chert" (P. E. Cloud, Jr., personal communication) that occurs near the base of the middle third of the Copper Ridge dolomite in Alabama and Georgia. The exact relation of the beds carrying this form to those carrying the Scaevogyra fauna is not knovn, but presumably they are slightly lower in the section. Inasmuch as Cloudia is unknown elsewhere, and as only fragmentary trilobites and possible pteropods are known in association with it, the genus is at present valueless for regional correlations. However, its large size and distinctive form make it extremely valuable in local correlation, and it (or forms closely allied to it) should be looked for in strata of equivalent age in other parts of the country. Its age, based entirely upon its known stratigraphic position, is either lates'. Franconia or early Trempealeau.

All these fossils indicate a definite cor"'elation between the upper two-thirds of the Copper Ridge and Conococheague formations of the Appalachian Valley and the Trempealeau and Madison formations of the upper Mississippi Valley section. Not all the faunal zones of this section have yet been identified in the Appalachian Valley. Possibly some of them never will be found, but probably most of the absences are due to lack of detailed mapping, changes in environment, or both, rather than to actual absence of time units.

The lower 250 to 300 feet of these formations presumably represents the Franconia sandstone of the upper Mississippi Valley section, but thus far no fossils, other than cryptozoans, have been found in these beds in East Tennessee and southern Virginia. Lower Franconia faunas do occur however in the Ore Hill limestone member in the lower part of the Gatesburg formation in central Pennsylvania, and as the Gatesburg is considered to be the general equivelent of the Conococheague on other grounds, the supposition that these unfossiliferous beds represent the Franconia interval is materially strengthened.

Because of the lack of physical evidence of a disconformity between the Maynardville limestcne member of the Nolichucky shale and the Copper Ridge and Conococheague formations, and because of the rather uniform thickness of the latter formations throughout the Appalachian region, the writer prefers to correlate the lower unfossiliferous beds of these formations with the Ore Hill member of the Gatesburg fcrmation of Pennsylvania, and through this member with the lower part of the Franconia sandstone of the standard Upper Cambrian section, and to ascribe the lack of characteristic faunas to environmental factors, such as conditions of sedimentation and preservation, rather than to erosion and nondeposition. It is believed that.further detailed mapping and collecting in the Appalachian 
Valley may eventually produce evidence of these missing faunas.

\section{CHEPULTEPEC DOLOMITE}

\section{NAME}

The Chepultepec dolomite was named by Ulrich (1911, p. 638-640), from Chepultepec, now Allgood, a small village on the Louisville and Nashville Railroad in Murphrees Valley about 31 miles northeast of Birmingham, Ala. According to Ulrich (1911, p. 639)

the section at the type locality begins in Murphrees Valley at Chepultepec Station [about 1 mile southeast of the village], which is located on the Conasauga formation, and passes upward through about 300 feet of non-cherty dolomite referred to the Ketona by Butts, then through approximately 1,700 feet of Conper Ridge cherty dolomites, then 300 to 400 feet of concealed beds thought to be "upper Knox", followed by about 1,000 feet of cherty magnesian limestone-the Chepultepec formation-and unconformably over this by Stones River limestone, which occupies the valley between Chert Ridge and West Red Mountain.

From this and other statements in the Revision of the Paleozoic Systems and from the accompanying correlation table (Ulrich, 1911, pl. 27), it would seem that Ulrich originally regarded the Chepultepec as younger than the "upper Knox" of Alabama and Tennessee, an error that was partly corrected without comment in a revised correlation table published a few years later (Bassler, 1915, pl. 2). The geology of the Birmingham 30-minute quadrangle that contains the type area was mapped by Butts (1910), but he made no attempt to subdivide the Knox except to split off the Ketona dolomite member at the base. The beds at Chepultepec were recognized as being younger than the bulk of the Knox dolomite elsewhere in the Birmingham Valley, but the entire sequence was assumed to belong to the lower part of the Knox dolomite and Butts (1910, p. $3,4)$ wrote that younger beds belonging to the Knox are to be found in the Cahaba Valley to the southeast. From the meager published record and from conversations with Ulrich and Butts, it would appear that the type section is in the row of hills immediately northwest of the village. No further detailed study of the Chepultepec dolomite in its type area has been made. Butts, however, mapped the geology of the four 15minute quadrangles immediately south of the Birmingham quadrangle (Butts, 1927, 1940a), and in these the Knox dolomite of the Birmingham folio was subdivided into a number of formations, one of which was the Chepultepec dolomite. This mapping established the position of the Chepultepec as directly orerlying the Copper Ridge dolomite and underlying the Longview dolomite.
As additional information was obtained, the name was extended to equivalent beds in Tennessee (Passler, 1915, pl. 1; Nelson in Gordon and others, 1924, p. 34, and Secrist, 1924, p. 16; Oder, 1934) and into Virginia (Butts, 1933 , p. $10 ; 1940$ b, p. 95 ff.), and the formation or its equivalents are now known to extend the length and breadth of the Appalachian Valley from New York to Alabama.

\section{IIMITS}

The Chepultepec dolomite, as used in this report, comprises units 305 to 406 of the beds in the Thorn Hill section (Hall and Amick, 1934, p. 199-203) and units 163 to 202 of the Lee Valley section (Rodgrors and Kent, 1948, p. 19-21). The lower boundary is drawn at about the middle of the thick series of calcareous sandstones that have already been described unter the Copper Ridge dolomite (p. 26-27).

The upper boundary is more difficult to place, particularly in fresh exposures, and in most areas is rather arbitrarily drawn, for the changes in bedrock lithology are so very slight as to make the transition from one formation to the other almost unnoticeable. The best evidence for the change from Chepultepec to Longview is found in the changes in the residual productsparticularly the cherts-in the fossils, and, in places, in topography. In the Thorn Hill section, the contact is assumed to lie at the base of a thin calcareou" sandstone forming the upper 2 inches of unit 406 ; elsewhere this sandstone is missing or unrecognized, and in practice the boundary is drawn on differences in residual chert and, wherever possible, on fossils.

The obscure nature of the Chepultepec-Longview contact is all the more surprising when it is remenbered that it has been interpreted as a plane of unconformity and that formations and faunas were believed to intervene between these two formations (Nelson, in Gordon and others, 1924, p. 34, and Secrist, 1924, p. 16; Butts, 1926 , p. 80 ; Oder, 1934, p. 481-482) ; in fact it was assumed to be a systemic boundary. Wherever tl ? writer has observed this contact throughout the entire Appalachian Valley, however, the Longview dolomite or its equivalents rest directly and conformably uron the Chepultepec dolomite or its equivalents; and he lnlieves that the same conditions will prove to hold t?ue for most of the areas in the central United States where the correlatives of these formations are exposed. The principal exception seems to be in the upper Mississippi Valley where the presence of a formation equivalent to the Longview dolomite lias not yet been conclusively demonstrated, and where beds roughly equivalent to the Kingsport and Mascot formations of this report appear to rest directly upon the Oneota dolomite which carries a Chepultepec fauna. 
In his report on the Burkes Garden area in Virginia, Cooper $(1944$, p. 27) implies that the Chepultepec is absent there, for "sandstone beds, believed to be characteristic of the Copper Ridge, occur directly beneath Lecanospira-bearing limestones" (Longview of this report), though "about 25 miles southwest of the Burkes Garden area, at Marion, Smyth County, Virginia, about 300 feet of Chepultepec limestone intervenes between the Conococheague (Copper Ridge equivalent) and the Lecanospira beds." Cooper concludes that "this may indicate the absence of the Chepultepec [in the Burkes Garden area]; on the other hand it is possible that the Chepultepec is represented by unfossiliferous dolomites and sandstones in the upper part of the Copper Ridge." Because of the great thickness (1,800 feet) assigned to the Copper Ridge in this area, the present writer believes the latter supposition is more probably correct.

\section{THICKNESS}

The Chepultepec dolomite is 689 feet thick in the Thorn Hill section and 721 feet thick in the Lee Valley section. Because of the lack of well-exposed sections, the lithologic similarity to adjacent formations, and the absence of fossils, the thickness of the Chepultepec dolomite in the Mascot-Jefferson City district is difficult to determine; it is believed, however, to be not less than 550 feet in the Mascot belt and may be somewhat more in the eastern belts. A fully exposed section in the valley of Loves Creek on the John Sevier quadrangle (base described on p. 27-28) has an outcrop width of between 850 and 900 feet and a calculated thickness of 562 feet for this portion of the section; it is by no means certain, however, that the arbitrary boundary selected is actually the top of the Chepultepec dolomite. At the abandoned TVA quarry about 1.25 miles westnorthwest of Cherokee Dam and a mile northwest of the bridge of State Highway 92 across the Holston River, the basal sandstones are exposed in the bed of Holston River, and about 300 feet of beds assigned to the lower part of the formation are exposed in the quarry face (see section, p. 39). Above the quarry are about 170 feet of poorly exposed strata representing the upper part of the formation, so that the total thickness of the Chepultepec in this area is at least 520 feet. The summit of the hill is capped by residual chert from the Longview dolomite, but it is by no means certain that this is in place.

\section{BEDROCK LITHOLOGY}

In the Mascot belt the Chepultepec dolomite is made up primarily of moderately thick beds of light-colored rather finely crystalline dolomite similar in most respects to the dolomitic layers in the upper part of the Copper Ridge dolomite. Most of the beds are a light steel gray but among them are a few individual layers that show a pinkish-brown or light-cho?olate color, which, however, is never as deep as the color found in the basal beds of the Copper Ridge dolomite.

The base of the formation is commonly marked by from 8 to 10 feet of coarse-grained soft rusty sandstone derived from the weathering of arenaceous dolomite layers and locally recemented to form hard quartzitic sandstone. Thinner sandstone layers are found above this bed through a thickness of about 100 feet, and a conspicuous bed of white siliceous oolite about 1 foot thick occurs about 32 feet above the base of the formation in the Loves Creek section (p. 28) and elsewhere through the district. This oolite differs from those in the underlying Copper Ridge dolomite in that the individual ooids are smaller in diameter (normally less than 1 millimeter), are white, and lack the conspicuous color banding that characterizes those in the Copper Ridge dolomite.

Ulrich (1911, pl. 27) did not recognize the Chepultepec dolomite in the "Knoxville trough," a term in which he included all the belts in the Mascot-Jefferson City district, and in the early mapping of this area in 1929 the present writer also failed to detect it. The following year, however, Oder, in extending the mapping of the previous year to the eastward, found Chepultepec fossils to the east and southeast of Jeffer:on City and conclusively demonstrated the presence of the formation throughout the district.

In the Jefferson City and Shields Ridge belts the formation becomes more calcareous and most of the strata composing it are best classed as slightly magnesian limestones. In these belts the dominant lithologic type is a finely crystalline medium- to dark-blue magnesian limestone. Beds commonly range from 6 or 8 inches to a foot or more in thickness and the major bedding planes are sharp and well defned. Minor bedding and lamination planes are uncommon. The rock breaks with a smooth, even, locally slightly conchoidal fracture. Interbedded with these magnesian limestones are beds of lighter colored more strongly dolomitic material. Both types contain considerable quantities of chert of various kinds in some layers.

The Chepultepec is one of the more soluble formations of the Knox group and good expo ures are not common. An almost complete section of the lower part of the formation is exposed in and above the TVA quarry on the south base of the 1,500-foot hill, 1 mile northwest of the bridge across Holston Biver on State Highway 92 on the Joppa quadrangle, 3 miles north of Jefferson City. This quarry, which supplied rock for fill and riprap in the construction of Clerokee Dam, was opened after the mapping was completed, and the 
following section was measured by R. A. Laurence and E. A. Finley, then of the Tennessee Valley Authority. ${ }^{15}$ Section of the lower two-thirds of the Chepultepec dolomite, exposed in the TVA quarry on Holston River, 1.25 miles northwest of Cherokee Dam

Top of quarry about $350 \mathrm{ft}$ above river level.

41. Dolomite, dark-gray, coarsely crystalline; a

single massive bed-D. Dolomite, light-gray, finely crystalline, with
40.

$\begin{array}{cc}\text { Unit } & \text { Total } \\ \text { thick- } & \text { thick } \\ \text { niess } & \text { ness }\end{array}$

$\begin{array}{cc}\text { ness } & \text { ness } \\ (\text { feet }) & (\text { feet })\end{array}$ thin bands of light-gray chert

39. Dolomite, light- and dark-gray, medium to coarsely crystalline; some scattered chert nodules

38. Chert, several types, mostly compact, white, angular ; in dolomite matrix

37. Dolomite, light- and dark-gray, finely crystalline, medium- to thin-bedded...........

36. Dolomite, coarsely crystalline, medium- to thick-bedded, with thin bands of chert....-

35. Dolomite, light-gray, finely crystalline; medium bedded at base becoming more thickly bedded toward the top; upper layer finely sandy

34. Dolomite, dark-gray, medium to coarsely crystalline, rather thin-bedded...........-

33. Dolomite, light-gray, medium-bedded, with chert bands.

32. Dolomite, dark-gray, medium to coarsely crystalline, medium- to thick-bedded...-

31. Dolomite, finely crystalline, light-gray, thinto medium-bedded.

30. Dolomite, finely crystalline, thin-bedded

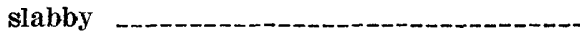

29. Sandstone, calcareous; light gray on fresh surfaces, weathering rusty brown

28. Dolomite, gray, finely crystalline; a single bed

27. Sandstone, calcareous, similar to unit 29...-

26. Chert, gray, compact._-_._._.

25. Dolomite, gray, medium to coarsely crystalline, medium- to thick-bedded.

$\begin{array}{rr}4.0 & 4.0 \\ 17.0 & 21.0 \\ 17.5 & 38.5 \\ 1.5 & 40.0 \\ 18.5 & 58.5 \\ 7.7 & 66.2\end{array}$

24. Sandstone, calcareous, similar to units 27 and 29

23. Dolomite, finely crystalline, banded light and dark gray, rather thick-bedded_...---

22. Dolomite, gray, coarsely crystalline, thickbedded

10.0147 .0

21. Dolomite, gray, finely to medium crystalline, thick-bedded thin- to medium bedded coarsely crystalline,

19. Dolomite, light-gray, finely crystalline, thick-bedded

18. Dolomite, cherty

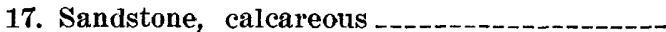

16. Dolomite, gray, finely crystalline, thinbedded

The original notes on this section were not avallable, and the descriptions and thicknesses given herewith have been compiled by the writer from a scale drawing ( 1 inch to 20 feet) furnished by the Tennecessee Valley Authority.
15. Dolomite, gray, finely crystalline, cherty

14. Dolomite, like unit $\mathbf{1 6}$

13. Dolomite, cherty, like unit $\mathbf{1 5}$

12. Dolomite, light-gray, finely crystalline, rather thick-bedded

11. Dolomite, dark-gray, coarsely crystalline, medium-bedded

10. Sandstone, calcareous

9. Dolomite, gray, finely to medium-crystalline, thick-bedded

8. Sandstone, calcareous

7. Dolomite, gray, finely crystalline, thickbedded

6. Sandstone, calcareous

5. Dolomite, like unit 7

4. Dolomite, gray, finely crystalline, thinbedded, weathers to thin slabs

3. Dolomite, gray, finely crystalline, thickbedded, with two or more thin $(0.5 \mathrm{ft})$ beds of calcareous sandstone. Bottom layer is at level of quarry floor.

$17.3 \quad 83.5$

3. 587.0

5. $0 \quad 92.0$

7. 299.2

$9.8 \quad 109.0$

$1.5 \quad 110.5$

$.7 \quad 111.2$

$2.3 \quad 113.5$

.5114 .0

.5114 .5

$10.0 \quad 124.5$

$2.5 \quad 127.0$

$10.0 \quad 137.0$

Total Total

thick- thick-

ness ness

(feet) (feet)

2.5197 .0

.5197 .5

.5198 .0

11. $3 \quad 209.3$

4. $5 \quad 213.8$

.6214 .4

56. $8 \quad 271.2$

1.5 272.7

5. $8 \quad 278.5$

$.7 \quad 279.2$

7. $7 \quad 286.9$

5. $0 \quad 291.9$

15.6307 .5

2. Largely covered interval between quarry fioor and river level. A few scattered ledges similar to beds in unit 12

1. Sandstone ledge, exposed in riverbed, thought to be the equivalent of unit 305 of the Thorn Hill section, and of the sandstone at the base of unit 15 of the Loves Creek section (p. 28)

6. 2 353. 7

NOTw.-The banded siliceous oolites characteristic of the urner part of the Copper Ridge dolomite also crop out in the bed of Holston River a few yards downstream from the sandstones of unit 1 .

Section of beds above TVA quarry

[Measured later by Laurence and Finley]

No outcrops to top of hill. Abundant large pieces of white chert.-.-.--

Dolomite, dark-gray, finely crystalline, with small angular chert fragments-.--_ine crystalline, thickbedded, with a few thin layers of dark chert Covered

Dolomite, dark-gray, finely crystalline, thinbedded, with a few thin layers of dark chert__- $\quad \begin{array}{lll}15.0 & 248.0\end{array}$

Thickness of beds above quarry

Thickness of section in quarry _._._.___._... 353. 7

Total thickness of beds in the two sections_._-_- $\quad 601.7$

A fair section of the dolomitic phase of the formation $19.5 \quad 189.5$ $2.5 \quad 192.0$

1. 0193.0 is exposed in the valley of Loves Creek in the v'estern part of the John Sevier quadrangle, but the fornation is very poorly exposed in the creeks to the east. A reasonably good section of the limestone phase of the formation is exposed in the valley of Mutton Creek in the Jefferson City quadrangle about 5 miles due scith of Jefferson City. Other good exposures of the limestone 
facies are found on the southeast flank of the Rocky Valley anticline on the eastern side of the county road about 0.75 mile north of Lebanon Church on the Jefferson City quadrangle; still other exposures can be found on either side of the road north of Buffalo Grove Church about 1 mile northwest of those just described. These outcrops expose only a small thickness of the formation but exhibit the composition of the limestone facies.

\section{RESIDUAL PRODUCTS}

The residual soils developed on the Chepultepec dolomite are commonly somewhat more brightly colored than those on the Copper Ridge or Longview dolomites. Dark-orange and reddish-orange tones predominate, and locally the soils are free from chert and sandstone debris.

Cherts of various types, some of them highly characteristic of the formation, are abundant at many localities.

One form of chert, common in the lower part of the formation, consists of oval flattened nodules as much as 8 inches in diameter and 2 inches thick. These occur with the longer axis parallel to the bedding planes and are believed to be syngenetic. The surfaces of these nodules are commonly stained a dull orange red. Freshly broken surfaces are black and show definite liesegang banding that is brought out by closely spaced curved concentric parallel fine white lines. These cherts are well developed in the lower part of the formation in the vicinity of Buffalo Grove Church and in the area immediately south of it on the southeastern flank of the Rocky Valley anticline.

Another very common and highly characteristic type is described by Ulrich $(1911$, p. 639) as "always relatively soft and more or less mealy in texture, and when resistant to the hammer it is because of toughness rather than hardness." These cherts are lightweight and highly porous, many of the cavities preserving the rhombic outlines of individual dolomite crystals from 1 to 2 millimeters in diameter. These impressions of dolomite crystals are an extremely constant and characteristic feature. The cherts are commonly light colored, ranging from white (on freshly broken surfaces) to various shades of cream, tan, yellow, and rusty brown. In general they are moderately fossiliferous.

Safford $(1869$, p. 215 , and footnote) describes these cherts as follows:

The chert in the uppel part, is to be noticed, inasmuch as it has supplied the gray, flinty gravel which, so extensively covers tlee ridges and knobs of this formation. This chert very generally has minute rhombohedral cavities interspersed through it, a character by which it may be distinguished from similar material in other formations.
I first observed these cavities many years ago. They present a character which has been of much use. At many points, loose chert is abundant on the surface, when the strata are entirely concealed. Among the dislocations of Eist Tennessee, it often becomes a question as to whether the rocks belong to the division under consideration, or to the S'liceous group [modern Fort Payne chert and associated strata], the chert of the two being much alike. The presence $o^{f}$. the cavities, I have, so far, found characteristic of the Knor. chert. They are the empty moulds of crystals of dolomite, once filling them. In rocks freshly quarried, showing chert, the crystals are seen. The chert of the Siliceous group, is, generally, characterized by the presence of large crinoidal buttons.

These dolomoldic ${ }^{16}$ cherts are virtually restricted to the Chepultepec dolomite in the Appalachian Valley and are rarely found at any other horizon. They are also rather characteristic of equivalent formations in such widely separated areas as Missouri and central Texas. In the latter areas some of the cherts are much harder than those in the Appalachian Valley, but they still exhibit the characteristic impression of the dolomite crystals.

These cherts appear to be developed in particular beds, but, as they do not appear in fresh exposures, they are probably selective replacements of a peculiar lithologic texture in which large crystals of dolomite were embedded in a more calcareous fine-grained groundmass, possibly a calcareo-siliceous groundmass. This type of chert is found at many localities.

A third type of chert consists of dull granular porous material containing many irregular brarching tubes, circular in cross section and averaging 0.25 inch in diameter. These cherts are dull gray $\mathrm{cn}$ weathered surfaces, but commonly stained various tones of red, reddish brown, and black on freshly broken surfaces. In form and texture they greatly resemble the Missouri cherts figured by Bridge (1930, pl. 13, especially 13b). Like the preceding variety, they are often fossiliferous, and like them they appear to be siliceous replacements of preexisting structures (possibly algae) in the limestome. Good accumulations are found in the fields north and northwest of the road corner 1 mile west of Buffalo Grove Church, Jefferson City quadrangle, and at many other places within the district.

Silicified cryptozoans, which are such o. conspicuous element in the Copper Ridge residual ruaterials, are almost completely absent in materials derived from the weathering of the Chepultepec dolomite. On the contrary, quartz cavity-fillings averaging 2 or 3 inches across are commonly found here but not in the Copper Ridge residuum.

16 A term proposed by Cloud and Barnes $(1948$, p. 17) to describe this texture. It replaces the earlier term dolocast, applied by McQueen (1931) to a similar texture. 
Arenaceous limestone or dolomite beds are common in the lower hundred feet and thin sandy beds rarely more than 2 or 3 inches in thickness occur sparingly throughout the formation. These weather to soft brown porous sandstone, fragments of which are present in the residual soils. These fragments are especially abundant near the base of the formation and in general they are indistinguishable from those in the Copper Ridge residual materials.

\section{FACIES RELATIONSHIPS}

The Chepultepec dolomite is a dolomitic or at best magnesian limestone unit, and until quite recently all regional correlations were made knowingly or unknowingly on this basis. Accordingly, the Chepultepec was considered to be equivalent to the Larke dolomite of the Pennsylvania section and to other dolomitic formations in the central United States (see p. 45). On the other hand, the Stomehenge limestone of Pennsylvania, which occupies the same stratigraphic interval and contains many of the same fossils, was correlated with the Tribes Hill limestone of the Mohawk Valley on the basis of lithologic and faunal similarity; these two formations were believed to be younger and to occupy the supposed time interval between the Chepultepec and Longview dolomites. This distinction and assumed difference in age was repeatedly stressed by Ulrich, Butts, Oder, and other workers in the Appalachian Valley.

Butts (1939) mapped the Larke and Stonehenge formations in different belts in the Tyrone, Pa., quadrangle, and commented on the absence of the latter formation in the Holidaysburg-Huntington quadrangle immediately to the south (Butts, 1945, p. 3). He also extended the Stonehenge limestone into Virginia (Butts, 1933, p. 11) but mapped it with the Chepultepec, and later (1940b, p. 101) suggested that it might be, in part at least, a facies equivalent of that formation, a suggestion that had already been made by Grabau (1937, p. $29,66-67)$.

At a field conference in 1934, attended by Ulrich, Butts, Oder, Pond, and the writer, Ulrich recognized the Stonehenge limestone in northeastern Tennessee, particularly in the belt passing through Church Hill in Hawkins County, and Oder (1934, p. 481-482) published this interpretation.

In the meantime, detailed studies on the brachiopods (Ulrich and Cooper, 1938) and on the cephalopods (UIrich, Foerste, Miller, and others, 1942, 1943, 1944) and unpublished work on the gastropods and trilobites by the writer and others have shown clearly that, although there are some differences between the faunas of the two groups of formations, they have many species in common (see discussion below under "Paleontolc ry and correlation"), and it now seems certain that the Tribes Hill and Stonehenge limestones are facies equivalents of the Chepultepec.

This interpretation brings the physical and paleontologic evidence into general agreement and disposes of the necessity of postulating a great unconformity between the Chepultepec and Longview dolomites, an unconformity for which there seems to be no physical or paleontologic evidence. The two formations apnear to be conformable at nearly every locality thus far studied (p. 37), and in addition there is a rather close relation between the faunas of the Chepultepec and the Longview dolomites, which suggests that no great time interval could have elapsed between them.

\section{PALEONTOLOGY AND CORRELATION}

The Chepultepec dolomite is moderately fossiliferous. Fossils are very rare in the dolomites and limestones themselves and where present are commonly unidentifiable unless silicified. The best and most abundant fossils are preserved in the cherts, commonly as external and internal molds. More rarely the fossil itself is silicified and stands out in relief on a limestone surface. The fauna is dominantly molluscar, with gastropods and cephalopods most abundant. T'ie lat-" ter group, although not completely unknown in older formations, makes its first appearance in large numbers and with great diversity of form in this formation; in fact, the finding of cephalopod fragments of any appreciable size is almost proof positive that the beds in question are of Chepultepec age or younger. Brack iopods and trilobites are next in importance among the Chepultepec faunas and members of these four classes alone make up between 90 and 95 percent of the known fauna. Minor elements are phyllocarid crustaceans, forms doubtfully classed as pteropods and chitons, and a few graptolites. The last were probably more abundant than their occurrence in the fossil faunas wonld indicate; their absence is most probably due to unfavorable conditions of preservation.

The complete fauna of the Chepultepec dolorite has never been described as a unit. Lists of species from it have appeared in various publications, among them Ulrich in Butts (1910, p. 4), Ulrich (1911, p. 639), Ulrich in Butts (1927, p. 4; 1940a, p. 7), Butts (1940b, p. 101), and Oder (1934, p. 480-481). A few of the more characteristic and distinctive fossils from the formation have been figured by Butts (1926, pl. 15; $1940 \mathrm{~b}$, pt. 2 , pls. 68, 69). Some of these lists have been republished by others without comment or correction (Grabau, 1937, p. 27). 
The lists mentioned above are unreliable, especially those that are unaccompanied by illustrations, for there are no descriptions and many of the generic and specific names were nomina nuda at the time of publication, and, although some of the forms have since been described under the names given, or under new names, many are still undescribed and the actual identity of some is not determinable. Furthermore, in the Alabama report (Butts, 1926), some of the specimens figured did not come from the Chepultepec dolomite in the Appalachian Valley but rather from equivalent strata in the central United States, statements in the report to the contrary notwithstanding.

A single example will suffice to show the unreliability of most of these lists. The list presumably prepared by 'Ulrich and given by Butts (1927) and repeated without comment or correction by Grabau (1937) and Butts (1940a) contains 30 species referred to 19 genera. Of these 19 genera, 9 were nomina nuda at the time of publication and 2 still are, and even of the 10 that are valid 3 had not been formally described at that time and are valid only because one or more of the species assigned to them had been previously described and assigned to some other genus.

Seven of the 30 species in the above list were designated as "sp." Of the 23 named forms, 14 were nomina ruda at the time of description and of these, 7 have since been validated, some of them under other generic names. This leaves only 9 species valid at the time of publication, and 2 of these were based entirely upon figures published without description in the preceding year.

Thus, out of the 19 genera and 30 species listed, only 10 genera and 9 species were actually valid at the time of publication and some of these were misidentified.

The list given by Oder (1934, p. 480-481) is much better. It contains 23 genera, all valid, although the presence of some of them in the Chepultepec dolomite is doubtful. The list contains about 54 species of which 7 are definitely identified with described forms, at least 14 others are designated as "cf." or "aff." described forms, and the remainder are designated as "sp." Such a list gives the reader a much better idea of the actual makeup of the fauna than the one used by Butts.

Detailed studies of the brachiopods (Ulrich and Cooper, 1938) and of the cephalopods (Ulrich, Foerste, Miller, and others, 1942, 1943, 1944) have been published; in these all the forms known from the Chepultepec dolomite and its equivalents elsewhere in North America are described and figured.

Lists of species, together with descriptions and illustrations of fossils from correlative formations in other parts of the country, have been published by Sardeson
(1896), Cleland $(1900,1903)$, Ulrich and Bridge, Ulrich and Foerste, and Ulrich in Bridge (1930), Dake and Bridge (1932), Bridge, in Sellards (1932, pls. II and III), Bridge and Cloud (1947), Cloud (1948), Cloud and Barnes (1948), and Ross (1951.). The following table, which is reasonably complete, as far as published forms go, has been compiled from recent sources and the nomenclature has been revised to conform to present usage. Only species which have been found in the Appalachian Valley either in the Chepultepec dolomite or in one of its recogeized equivalents are listed; their distribution elsewher 3 is indicated by appropriate symbols.

The Chepultepec fauna is one of the most widely distributed faunas of early Paleozoic age in the United States and forms an excellent datum for regional correlation. In the Appalachian Valley the Chepultepec is to be correlated directly with the Larke dolomite of Pennsylvania and possibly with all or at least the greater part of the underlying Mines dolomite. It also seems to be equivalent to the Stonehenge limestone of Pennsylvania and of the Tribes Hill limestone of New York (see section above on facies relationships). Many species found in the Chepultepec-Tribes Hill faunas occur in the Oneota dolomite of tha upper Mississippi Valley region; in the Van Buren and Gasconade dolomites of Missouri; ${ }^{17}$ in the Kindblade formation of the Arbuckle uplift; and in the Tanyard formation of central Texas. Still farthor west, elements of this fauna have been found in the so-called Bliss sandstone near Van Horn, Tex. (King, 1940, p. 154-155; Cloud and Barnes, 1948, p. 360-361) but not in the type area of the Bliss sandstone at El Paso. Elements of this same fauna also occur in the Manitou limestone of Colorado, in the lower part of the Pogonip limestone of the Great Basin area, anc' in the Mons formation of Alberta in the Canadian area. Finally some of the species characteristic of this fauna have been found in the Cass Fiord formation of northern Greenland (Poulsen, 1937).

The Chepultepec dolomite has been var: ously classed as Upper Cambrian, Cambrian or Ordovician, and most recently Lower Ordovician. It seens to be separated from the older formations by a minor but widespread disconformity, the physical evidere for which is clear at some places (Bridge, 1930, p. 142-145; Dake, 1930, p. 128-129), ${ }^{18}$ less clear at others. As would naturally be expected, the physical evidence is strongest

17 The Van Buren and Gasconade formations as described by Bridge (1930) are now considered by him to be a singls formation, the Gasconade.

18 Recent work by geologists of the Missouri Geolorical Survey may indicate that the evidence for the disconformity is not: as definite as it was thought to be by Dake and Bridge. 
TABLE 1.-Distribution of species from the Chepultepec dolomite

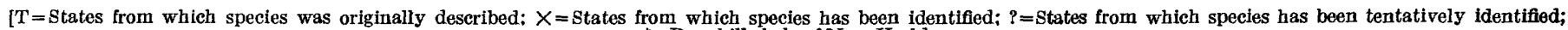
=Deepkill shale of New York]

Graptolites:

Airograptus furciferus Ruedemann.

Clarkella depressa Ulrich and Cooper

Finkelnburgia bellatula Ulrich an

Cooper.
buttsi Ulrich and Cooper.

plicata Ulrich and Cooper

plicata Uirich and

Glyptotrophia marylandica Uirich an

Cooper.

a? clelandi Ulrich and Cooper

anorthis difficilis Ulich and Cooper

Schizambon pennsylvanicum Uirich and

Cooper.

Syntrophina campbelli (Walcott)

impressa Ulrich and Cooper

Tetralobula delicatula Ulrich and Cooper

Gastropods:

Bellerophon calicifer Cleland.

subovatus Cleland

Chepultepecia leiosomella (Sardeson)-

Eccyliomphalus multiseptarius Cleland cf. E. gyroceras (Roemer)
omphalopsis involuta Ulich and

Buomphalopsis involuta Ulr

robusta Uirich and Bridge

Gasconadia putilla (Sardeson)

elicotoma uniangulata (Hall) .........

winonensis (Sardf Son)
Hemithecella ex pansa Ulrich and Bridge

Holopea? raymondi Cleland

voluta Cleland

Ophileta complanata Vanuxem

cf. O. complanat

hunterensis (Cle

supraplana Ulrich and Bridge

supraplana Urich and Bridape solida Butts

Ozarkina complanata Ürich and Bridge aff. O. complanata

typica Ulrich and $\mathrm{Bridge}$

ozarkispira subelevata Ulrich and

Bridge.

Pleurotomaria floridanus Cleland

Raphistoma obtusa Cleland

(1) umbilicata Ulrich and Bridge

vera Ulrich and Bridge

humerosa UIrich

turgida (Hall)

Schizopea grandis (Uilrich and Bridge) Cephalopods:

Bassleroceras clelandi Ulrich, Foerste, Miller, and Unklesbay -... Ulrich,

Bathmoceras? tennesseense Ulrich, Burenoceras peramplum Ulrich, Foerste, and Miller cf. B. ungulatum Ülrich, Foerste, Caseoceras conicum Ülrich, Foerste, Clarkoceras buttsi Ürich, Foerste, and Miller Clarkoceras? clelandi Ulrich, Foerste, and Miller

Clarkoceras curvatum Ürich, Foerste, and Miller................................... jasperense Uirich, Foerste, and
Miller

cf. C. newton-winchelli (Clarke) parvisiphonatum Ulrich, Foerste, and Miller mohawkense Ulrich, Foerste, and Miller

Conocerina? bassleri Ürich, Foerste, and Miller

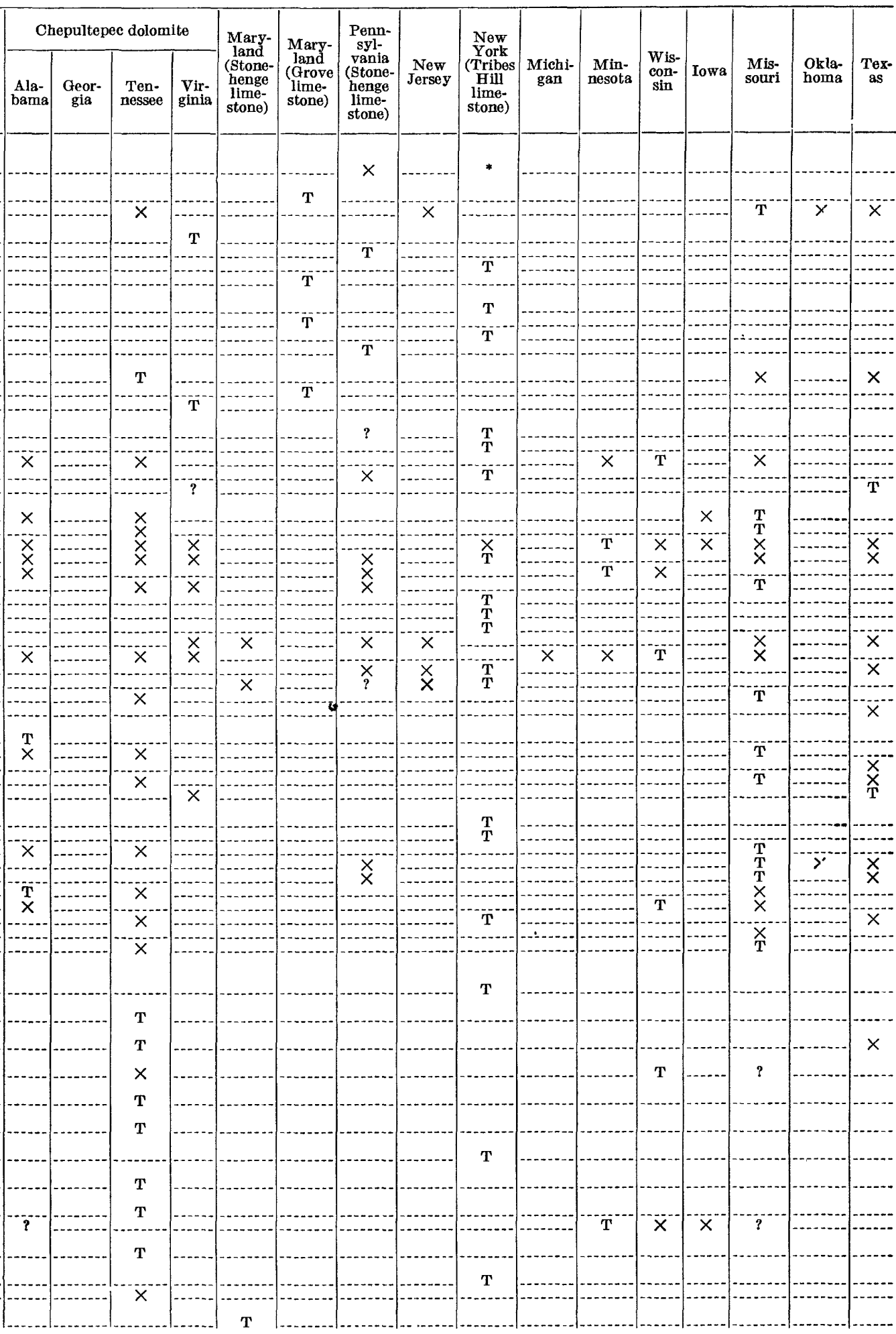


TABLE 1.-Distribution of species from the Chepultepec dolomite-Continued

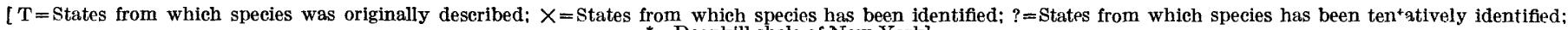
* = Deepkill shale of New York]

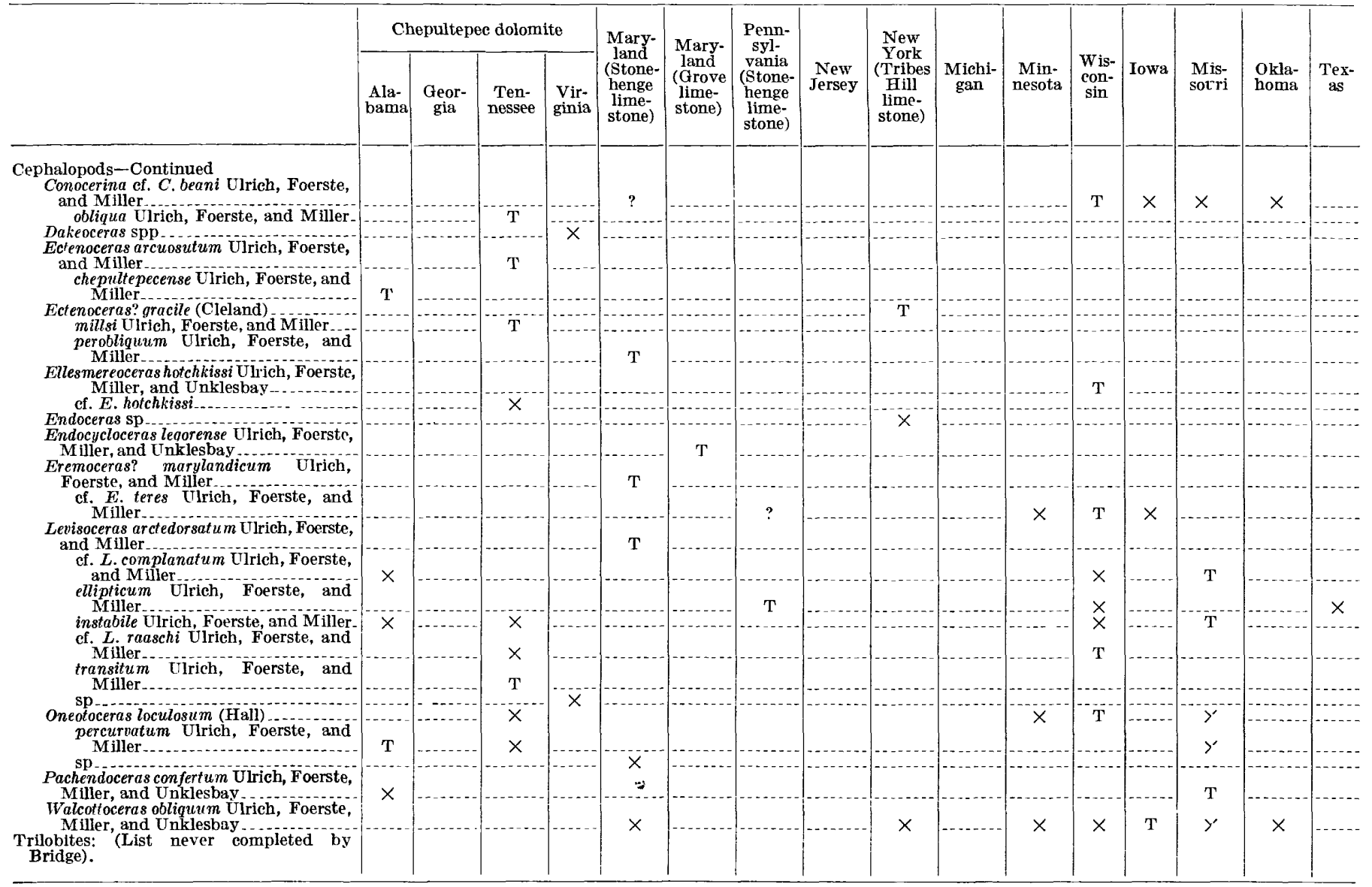

around old positive areas, such as the Adirondack uplift, the pre-Cambrian shield in Wisconsin and Minnesota, the Ozark dome, and the Llano uplift in Texas. Conversely the evidence is less strong in geosynclinal areas such as the Appalachian Valley, the Arbuckle uplift, and the Cordilleran area.

The principal evidence for drawing a systemic boundary between the Copper Ridge and Chepultepec dolomites and their equivalents is found in the abrupt faunal changes which occur at this boundary. These are of two types: the sudden development and expansion in the Chepultepec dolomite of classes of fossils that are absent, or at best only faintly represented, in the older formations, and the almost complete extinction of genera and families belonging to certain classes that were abundant in the older formations and their replacement in the younger formations by new groups.

The first type of change is represented by the nautiloid cephalopods. The early members of this group have recently been made the subject of an intensive study by Ulrich, Foerste, Miller, and others $(1943,1944)$, in the course of which all forms known from the Knox group and older formations of the Appalachian Valley and their equivalents throughout the United States were studied and described.

Only a single genus, Shelbyoceras, represented by three species, has been found in the Copper Ridge dolomite and its equivalents, ${ }^{19}$ but beginning with the Chepultepec the nautiloid group is represented by 26 genera and 199 species in which two of the three major divisions of this group, straight and curved types, are represented. The original source of this cephalopod fauna and the reasons for its sudden appearance are unknown, but the latter certainly suggests a rather sudden and drastic change in ecologic conditions.

The trilobite, gastropod, and brachiopod faunas all show changes of the second type. Among the trilobites there is an almost wholesale extinction of genera and families of the so-called Cambrian types at the close of Copper Ridge time and their replacement ir the Chepul-

$19 \mathrm{R}$. H. Flower, in a letter in 1951 , states that additional specimens belonging to other groups have been found in some of the high Upper Cambrian strata of central Texas, but even so the number of forms found in the Cambrian is still very small. 
tepec dolomite by new groups. Studies on this group are admittedly incomplete, but at present no genera are known to cross this boundary. Furthermore, the trilobites cease to be the dominant element in the faunas, and from here on are always subordinate both in kinds and in numbers of individuals.

Among the gastropods, Sinwopea, Schizopea, and Pelagiella, are common to both groups of formations, though represented for the most part by different species; most of the abundant Cambrian genera disappear at this boundary, however, and are replaced in the Chepultepec by a host of new forms whose affinities are largely with forms found in younger formations.

Furthermore, the gastropods, which have nearly always been a minor element in the Cambrian faunas, suddenly become the dominant element in the Chepultepec faunas, not only in numbers of individuals but also in numbers of genera and species. If the studies on this group had been completed in the same detail as those on the cephalopods, the list on page 43 would be nearly twice as long.

Like the cephalopods, the brachiopods on both sides of the Cambrian-Ordovician boundary have recently been studied by Ulrich and Cooper (1938). A few longranging genera, Finkelnburgia and Westonia, cross the boundary, but 5 genera die out at the top of the Cambrian, and 2, possibly 3 , die out in Chepultepec time. On the other hand, 11 genera appear for the first time in the Chepultepec; many of these continue into higher beds of Early Ordovician age and some extend into Middle Ordovician strata. Three of these 11 genera are doubtfully reported from the Upper Cambrian, but their occurrence may be based on misidentification of the formations involved.

Data on other groups are less complete but seem to be in line with those of the four dominant groups just mentioned.

\section{RELATION TO THE LONGVIEW DOLOMITE}

Although there appears to be no disconformity between the Chepultepec and the Longview dolomites, it has been repeatedly stated that such a break exists. The idea was first adrocated by Ulrich (in Bassler, 1915 , pls. 1,2) and was subsequently reaffirmed by Butts, Oder, and many others, including the writer. The main basis of this idea is found not in physical evidence of a disconformity that can be seen in any given section, but rather in the assumption that certain formations carrying specific faunas intervene between the Chepultepec and Longview dolomites or their recognized equivalents. The best evidence for this assumption is found in central Pennsylvania, where in some areas the Stonehenge limestone lies between the Mines and the Nittany dolomites, whereas in others the Larke dolomite lies between the same two units. The Mines dolomite is correlated with the upper part of the Copper Ridge or the lower part of the Chepultepec dolomite, ${ }^{20}$ and the basal part of the Nittany dolomite is admittedly the equivalent of the Longview.

Nowhere so far as known do all four formationsMines, Larke, Stonehenge, and Nittany-occur in the same section; the sequence is either (1) Mines, Tarke, Nittany or (2) Mines, Stonehenge, Nittany. From this, the assumption of disconformity arose. Except for New York State where the Tribes Hill limestone, the equivalent of the Stonehenge, was believed to occupy a similar position, there are no formations in other parts of the country that are known to lie between the equivalents of the Chepultepec and Longview dolomites, though the existence of such beds has been sugirested by Ulrich, Oder, and the writer in Oklahoma, Tennessee, and Texas, respectively. These, however, were the result of miscorrelation, and the only remaining strongholds of the so-called disconformity lie in central Pennsylvania and in the Mohawk Valley. Butts and Moore (1936, p. 20) gave typical evidence for the disconformity: "as the Larke dolomite is not gen rally recognizable and is believed to be generally absint in the Bellefonte quadrangle, there is a hiatus betwe?n the Mines and the Stonehenge due to its absence." This statement, of course, is not necessarily true.

In the northwestern part of the Tyrone quadrangle (Butts, 1939) the Stonehenge limestone is mapped as resting directly on the Mines dolomite, and the belts in which this relationship is shown continue on to the Bellefonte quadrangle to the northeast (Butts and Moore, 1936).

In the southwestern part of the Tyrone quadrangle the sequence is different, for in this area the Larke dolomite overlies the Mines, and in turn is overlain by the Nittany dolomite, the Stonehenge limestone being absent. The belts in which this sequence occurs continue to the southwest on to the Huntington and Hollidaysburg quadrangles (Butts, 1945), no Stonehenge being mapped in either of these two quadrangles. The geographic distribution of the two formations, Stonehenge and Larke, strongly suggests that here is another example of an intergrading limestone-dolomite facies, limestone to the northwest and dolomite to the south-

20 Resser and Howell (in Howell and others, 1944) placed the Mines dolomite in the Upper Cambrian and made it the npper member of the Gatesburg formation, but Butts (Butts and Moore, 1936, p. 18; Butts, 1939 , p. $13 ; 1945$, p. 3) lists three species of Sinuopea from the base of the Mines. In the first two reports Butts also classes the formation as Cambrian but in the final one he places it at the base of the Ordovician. If these gastropods are correctly identified, they indicate that the Mines is post-Copper Ridge and equivalent to the lower part of the Chepultepec dolomite. 
east. This supposition is strengthened by various comments in the texts of the publications just cited which indicate that the distinctions between the Larke and the Stonehenge are not nearly so clean cut as the mapping would suggest and that occasionally there has been some doubt in the mind of the author as to which formation was actually present. For example, in the Hollidaysburg-Huntington folio (Butts, 1945, p. 3), it is stated that

in these quadrangles the Stonehenge, which underlies the Nittany farther east, is not certainly known, but it may be represented by a few feet of dark, compact limestone at the base of Nittany exposed about four-fifths of a mile southeast of Ore Hill. About 10 feet of thin-bedded dolomite is exposed beneath this limestone at that point.

On the other hand it is stated (Butts and Moore, 1936, p. 19) that

the Larke is not generally recognizable or mappahle in the Bellefonte quadrangle, but [that] limestone believed to represent the Larke is exposed in an old ore pit $1 \%$ miles $N .75^{\circ} \mathrm{W}$. of Scotia. . . . Here about 200 feet of vertical rock has been exposed. It is mainly dolomite but includes thick layers of fossiliferous limestone near the middle. In this bed of limestone occul's a large gastropod provisionally referred by Ulrich to Helicotoma vinonensis (Sardeson); a large Ophileta shown in cross section and not positively identifiable specifically, but comparable to $O$. grandis; and numbers of specimens of a species of Hemitheca [Hemithecella]. . . A As the Larke also bebelongs to this general zone, the fossiliferous beds at the old ore pit are identified with the Larke. However, as the Larke is elsewhere unknown in the region and its known area in the old pit is very small, it is mapped with the Stonehenge in what seems to be a small fault block as shown on the geologic map.

Both of these quotations suggest the presence of an intergrading limestone-dolomite facies, and it is rather surprising that Butts, who was usually keenly aware of such gradations and their stratigraphic significance, failed to recognize it. He had his doubts on the subject, however, for in 1935 in the course of a field trip into the Tyrone area he remarked to the writer that it was very strange that the belt between the Mines and Nittany dolomites was always wide enough for one formation, either the Larke or the Stonehenge, but never wide enough for both, and at that time he seemed to be trying to convince himself of their equivalence. Later on (Butts, 1940b, p. 101), he stated that

the occurrence of several common species in the Chepultepec, Stonehenge, and Tribes Hill of New York has led some geologists to the tentative conclusion that those formations are all the same.

And at that time he had practically accepted this view in spite of seemingly later statements to the contrary such as the following (Butts, 1945, p. 3) : ${ }^{21}$

21 It should be remembered that the texts of the Bellefonte (Butts and Moore, 1936), Tyrone (Butts, 1939), and Hollidaysburg-Hunting-
At Bellefonte, in Centre County, the Mines dolomite is succeeded above by the Stonehenge limestone, which is 662 feet thick. Throughout most, if not all, of these quadrangles [the Hollidaysburg and Huntington quadrangles], however, the Stonehenge limestone is absent and the Larke dolomite is overlain unconformably by the Nittany dolomite.

Recognition of this facies relationship appears to have been delayed by Ulrich's view that the faunas of the two groups of formations are different and that the fossils of the Tribes Hill and Stonehenge limestones are younger than those of the Chepultepec and its equivalents. While differences do exist, the two groups of formations have many species in common, and had the facies relationship been recognized at the time when certain fossils were being described, more identical species would probably have been recognized in the two groups.

The writer's present view is that there is no convincing evidence, either physical or faunal, to prove the existence of a hiatus between the Chepultepec and the Longview dolomites and their equivalents elsewhere, and they are here regarded as a part of a conformable sequence.

\section{LONG VIEW DOLOMITE}

NAME

The name, Longview dolomite, was firs ${ }^{+}$published by Nelson, in a correlation chart based on Ulrich's ideas (Gordon, 1924, p. 34; Secrist, 1924, p. 16). The formation was first described by Butts (1926, p. 92-95) as the Longview limestone. The name was taken from exposures near Longview, Shelby County, Ala., and the formation was subsequently mapped in the BessemerVandiver and Montevallo-Columbiana folios (Butts, $1927,1940 \mathrm{a})$, the latter folio containing the town for which the formation was named and what may be considered its type area. No type section was ever described, and Butts states that the formation boundaries are not well exposed in the vicinity of Longview. He also lists (Butts, 1926, p. 92) three sections in Cahaba Valley and on Little Cahaba River which may well serve as typical sections.

The name was reintroduced into Tennessee during the course of this investigation as a substitute for the Pennsylvania name Nittany dolomite (Hall and Amick, 1934; Oder, 1934). This was done at the suggestion of Ulrich, who claimed that the Nittany formation in its type area in central Pennsylvania contained more time and faunal units than its so-called equivalent in Tenr ossee and suggested that until more detailed information about the Nittany in its type area became available it would be

ton (Butts, 1945) reports had all been written many years before their publication and that Butts' report on the geology of the Appalachian Valley in Virginia, though dated 1940 , actually presented his last published views on this subject. 
advisable to discontinue use of the name in Tennessee. The name Longview has been used as a formation name in Tennessee in several recent publications, notably Oder and Miller (1945) and Rodgers and Kent (1948). Though these publications do not entirely agree on the limits of the formation, both, as well as most other recent papers, have considered the Longview to be a formation. Allen (1947) on the other hand has regarded it as the lower member of an enlarged and expanded Kingsport formation.

\section{IIMITS}

The Longview dolomite in East Tennessee comprises units 406 to 458 of the Thorn Hill section (Hall and Amick, 1934, p. 203-205) and units 203 to 239 of the Lee Valley section (Rodgers and Kent, 1948, p. 22-25). Throughout the Valley of East Tennessee it is invariably underlain by the Chepultepec dolomite and overlain by the Kingsport limestone; these relations extend northward into Virginia and southward into Alabama and Georgia. The gradational contact with the Chepultepec dolomite has been described (p. 37). The upper contact is likewise conformable with the overlying Kingsport, but, because of sharp lithologic differences, the topography resulting from them, differences in the residual cherts, and differences in fossil content, it is generally much easier to place. In the Thorn Hill and Lee Valley sections and throughout the Mascot-Jefferson City district, this contact is commonly drawn at the base of a unit of aphanitic lightbluish to brownish semilithographic and normally moderately fossiliferous limestone from 25 to 50 feet thick. The individual beds of this limestone unit are in general a foot or more thick and are characterized by thin crinkly shale partings at intervals of about an inch. Locally, as on Copper Ridge and elsewhere, the upper part of the Longview also contains beds of fine-grained to aphanitic limestone that superficially resembles the limestone assigned to the overlying Kingsport in color and general texture. These layers are commonly much thinner and more discontinuous, however, and typically they lack the irregular crinkly shale partings that characterize the basal limestone of the Kingsport. Oder, Allen, and others have suggested that these thinner limestones also be included in the Kingsport, but the presence of Lecanospira in these beds in the Thorn Hill section and elsewhere indicates that they belong with the Longview dolomite.

\section{THICKNESS}

The Longview dolomite is 230 feet 8 inches thick in the Thorn Hill section and 264 feet thick in the Lee Valley section. It maintains a comparable thickness throughout the Mascot-Jefferson City district, though exact measurements between its contacts have been difficult to obtain. The calculated thickness of tho section on Loves Creek is between 458 and 554 feet. but here, as noted above, there is uncertainty as to the position of the contact between the Chepultepec and Iongview dolomite, which may have been placed too low in the section.

In the chart published by Nelson, the Longviow is given a thickness of 1,000 feet, but this thickness doubtless included beds now assigned to underlying and overlying formations. Butts (1926, p. 93, and elsewhere) gives a thickness of from 400 to 500 feet for secticns in Alabama, and Oder $(1934$, p. 482$)$ states that the thickness varies from 25 to 250 feet. These abnormally large and small thicknesses appear to depend on the ass $1 \mathrm{mp}$ tion that unconformities exist at the top and bottom of the formation and upon miscorrelations. The failure to find the distinctive faunal zones of the I rongview has many times resulted in its strata being placed either in the Chepultepec dolomite or in the overlying formation.

As pointed out by Rodgers and Kent (1948, p. 25-26), the contact between the Longview and Kingsport used herein lies about 100 feet above the contact as d"awn by Oder and Miller (1945) and appears to correspond exactly to the "zero bed" or "footwall sand" of the Mascot mine section described by them, though $r$ ?t to the "zero beds" of the New Market or Jefferson City sections.

\section{BEDROCK IITHOLOGY}

The bulk of the formation is composed of thin- to thick-bedded well-bedded fine-grained light-colored dolomite that closely resembles the dolomite in tho underlying Chepultepec. The upper half or third of the formation may include beds of fine-grained to aphanitic light-bluish-gray limestone, which locally may make up half of the upper part of the formation. Both the limestone and the fine-grained dolomite are locally replaced by a coarser grained "recrystalline" dolomite that is clearly younger than either of the primary types of rock. The transition from original carbonate into recrystalline dolomite is commonly sharp, and hand specimens showing both at once are easy to obtain. The recrystalline material is common in areas of structural complexity, along fault and shatter zones, and in areas of brecciation; it is invariably present where there is zinc mineralization though not all recrystalline areas contain zinc. As a general rule, the limestone is much more commonly replaced than the fine-grained dolomite, yet examples of both types of replacement $c n$ be found. 


\section{RESIDUAL PRODUCTS}

The rocks of the Longview dolomite commonly weather to a light-ash-gray soil that is in rather sharp contrast with the more highly colored soils developed on the Chepultepec and Kingsport formations. Weathered surfaces of the Longview rocks are commonly lighter than the fresh rock; light-gray, bluish-gray, and tan tones predominate. In the fine-grained dolomites, solution appears to be most active along closely spaced microscopic fracture planes. These are practically invisible in the unweathered rock but appear on weathered surfaces as narrow subparallel sets of gashes that intersect each other at various angles and give the dolomite a curious slashed appearance that is particularly noticeable on exposed bedding surfaces. This type of weathering is not confined to the dolomites of the Longview but is associated with fine-grained dolomite throughout the Knox group; it is one of the most useful criteria for distinguishing between limestone and dolomite.

Ordinarily the Longview yields abundant chert on weathering, but locally there may be almost none. Most of the chert belongs to a type that is highly characteristic of the formation, and a study of the residual materials affords the best means of separating the Longview from the associated formations. The bulk of it consists of massive porcellaneous dead-white to light pink, brown, and gray chert in large blocks as much as 2 feet or more in diameter. This chert is brittle and compact, very rarely cavernous, and never mealy or porous. Like the dolomite from which it is derived, it is cut by many closely spaced microscopic joints, and upon weathering it breaks down into small rectangular blocks and splinters that are normally white or light yellow though fairly commonly stained with iron and manganese oxide. Round or oval chert nodules occurring in specific layers, such as are characteristic of the Chepultepec and Kingsport formations, are not common in the Longview. Oolitic chert is sparingly present, and dolomoldic chert and the porous, ropy, and anastomosing chert that is such a conspicuous feature of certain parts of the Chepultepec dolomite are rare. Sandstone beds are thin and inconspicuous, though rounded sand grains occur in certain dolomite and limestone layers.

The chert of the Longview is well displayed in the ridge north of the John Sevier railway yards, on the low hill just west of Roseberry Creek at Mascot, in the ridge north of Friends Station, and in the high part of Crockett Ridge about 3 miles northwest of Morristown.

\section{PALEONTOLOGY AND CORRELATION}

Fossils are not abundant in the Longview dolomite, and most of those found occur as internal or external molds in residual cherts derived from the weathering of the formation. It is almost useless to search for fossils in fresh or even well-weathered exposures of the dolomite and limestone; the best collecting is commonly on the chert-covered hillsides where there are few or no outcrops. For this reason it is generally difficult or impossible to attribute collections to defnite parts of the section, and only in a few places is thare the fortunate combination of circumstances that makes this possible.

The fauna thus far recovered from the Longview dolomite and its equivalents in the Appalachian Valley is given in the following table.

The brachiopods occasionally provide an exception to the foregoing statements concerning the rarity of fossils in limestone, for locally they do occur as silicified shells in a limestone or dolomite matrix, from which they can be freed by etching witl acid. They are, however, not abundant in the Appalachian Valley, only six species having been recorled and only two of these from Tennessee. They ar much more abundant in equivalent formations in Oklahoma and Texas and there they form a most important element in the faunas.

The most important and characteristic fossils of the Longview dolomite, both from the $\mathrm{s}^{+}$andpoint of abundance and ease of recognition, are th 9 gastropods, particularly the genera Lecanospira and Rhombella, both of which seem to be confined to this formation and its equivalents. Of these, Lecanospira is by far the more abundant, the more widely distributed, and the more easily identified. Specimens belonging to various species of the genus have been found tl roughout the length of the Valley from Alabama to Quebec, and also in Newfoundland and in the Durness limestone at the northern tip of Scotland. The genus is abundant in the Roubidoux formation of Missouri (Bridge, 1930, p. 124) and in the Gorman formation of central Texas (Dake and Bridge, 1932, p. 737; Clouc ${ }^{1}$ and Barnes, 1948 , p. 40). It also occurs in the Cool Creek formation of the Arbuckle and Wichita Mountains and possibly at a level equivalent to the Gormar formation in the El Paso limestone of West Texas (Cloud and Barnes, 1948, p. 359). It has not yet been reported from the Rocky Mountains or from areas farther west. Rhombella (formerly called Roubidouxia) is nearly as widely distributed and about as characteristic, but it is much less abundant than Lecanospira. It is found mostly as molds in residual cherts, but specimens in limestone have been found at a few localities, particu- 
TABLE 2-Distribution of species from the Longview dolomite and equivalent formations

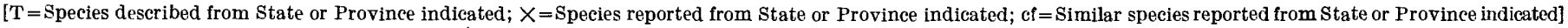

\begin{tabular}{|c|c|c|c|c|c|c|c|c|c|c|}
\hline & \multicolumn{3}{|c|}{ Longview dolomite } & \multirow{2}{*}{$\begin{array}{l}\text { Mary- } \\
\text { land }\end{array}$} & \multirow{2}{*}{$\begin{array}{c}\text { Pennsyl- } \\
\text { rania }\end{array}$} & \multirow{2}{*}{$\begin{array}{l}\text { New } \\
\text { York }\end{array}$} & \multirow{2}{*}{ Quebec } & \multirow{2}{*}{ Missouri } & \multirow{2}{*}{ Texas } & \multirow{2}{*}{$\begin{array}{l}\text { Okla- } \\
\text { homa }\end{array}$} \\
\hline & $\begin{array}{c}\text { Ala- } \\
\text { bama }\end{array}$ & $\begin{array}{c}\text { Ten- } \\
\text { nessee }\end{array}$ & $\begin{array}{l}\text { Vir- } \\
\text { ginia }\end{array}$ & & & & & & & \\
\hline 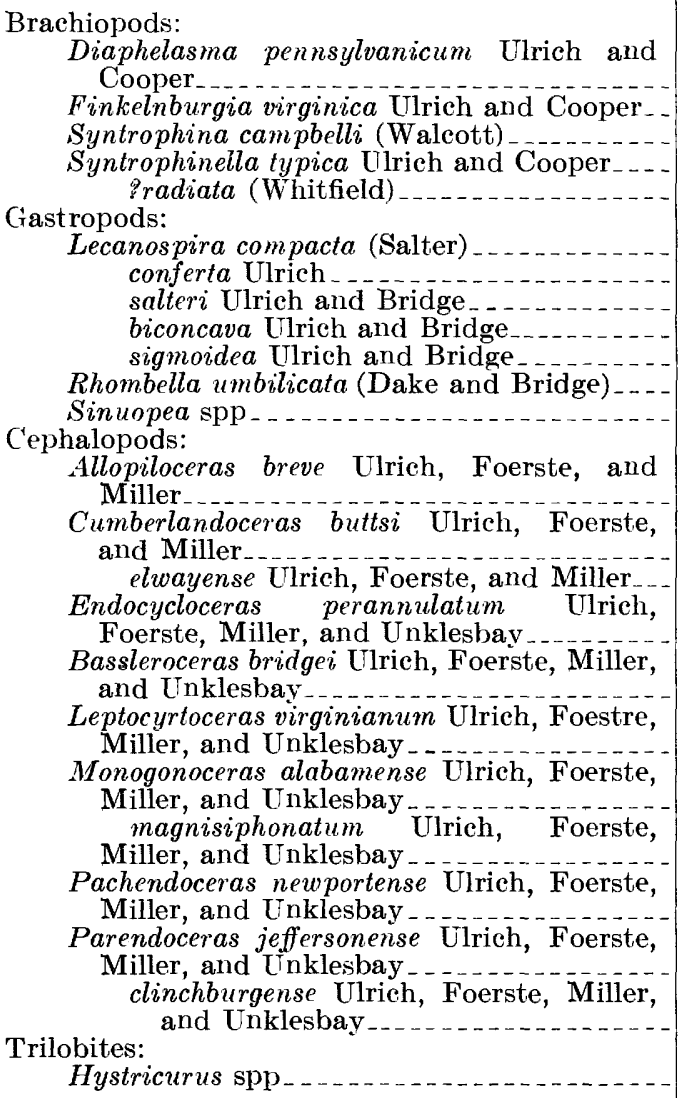 & \begin{tabular}{c}
$x$ \\
$\mathrm{~T}$ \\
\hdashline$x^{-}$ \\
\hdashline$-\cdots$ \\
\hdashline$-\cdots$
\end{tabular} & $\begin{array}{c}\mathrm{X} \\
\mathrm{T} \\
\mathrm{X} \\
\mathrm{T} \\
\mathrm{X} \\
\mathrm{T} \\
\mathrm{X} \\
\mathrm{T} \\
\mathrm{T} \\
\mathrm{T}\end{array}$ & 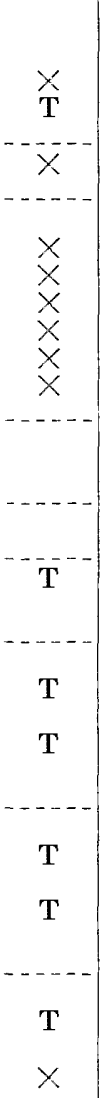 & 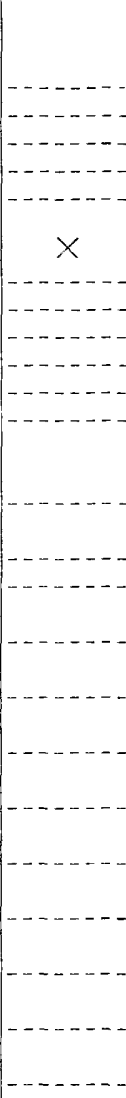 & 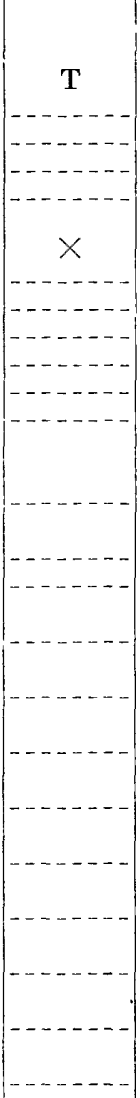 & T & $\mid$\begin{tabular}{c}
$\mathrm{T}$ \\
$-\mathrm{X}^{-}$ \\
\hdashline $\mathrm{X}^{-}$ \\
\hdashline$-\cdots$
\end{tabular} & \begin{tabular}{c}
$X_{X}$ \\
$X$ \\
$\mathrm{~T}$ \\
$\mathrm{X}$ \\
\hdashline
\end{tabular} & 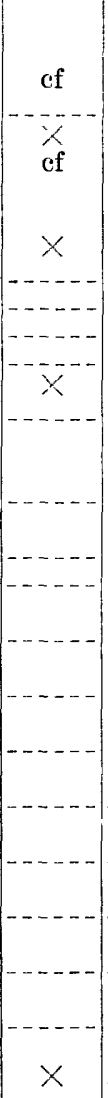 & מ \\
\hline
\end{tabular}

larly in Oklahoma and Texas and to a lesser extent in the northern Appalachians, in Pennsylvania and New York, and in certain areas in Quebec.

\section{KINGSPORT LIMESTONE}

\section{NAME}

The Kingsport limestone is named from exposures along U. S. Highway 23, beginning about 0.5 mile north of the junction of this road with U. S. Highway 11-W just north of Kingsport, Sullivan County, Tenn. The name was originally suggested by Oder (personal communication about 1937 for use in the present report. It replaces the names Jefferson City formation (Oder, 1934) and Forked Deer formation (Hall and Amick, 1934).

The name Jefferson City was discarded as a formation name in Tennessee to avoid confusion with its long-standing use in Missouri and Arkansas. The name has had a long and varied history in the Ozark region, and its present status there is not very well defined. The Jefferson City formation of the Ozark region, as originally proposed by Winslow $(1894$, p. 331), included all strata between the Roubidoux sandstone beneath and the Saccharoidal (St. Peter) sandstone above. Jlrich (1911, p. 632-633, pl. 27) restricted the Jefferson City limestone to the lower third of the rocks in this interval; subsequently Purdue and Miser (1916, p. 4-5) introduced the names Cotter dolomite and Powell limastone for the remaining two-thirds of the original Jeferson City of Winslow. Still later, Dake (1921, p. 12) raised the Jefferson City to the rank of a group composed of three formations, the Jefferson City formation (restricted) at the base followed by the Cotter and Powell dolomites. The boundaries of the three formations were never clearly defined. In brief, in the typ? area of the Jefferson City dolomite in and around Jef erson 
City, Mo., no Cotter is present, whereas at Cotter, Ark., the type locality for the Cotter dolomite, which is about 140 miles to the south on the opposite flank of the Ozark dome, the contact between Jefferson City and Cotter is below river level. As a result, the assumed contact between the two formations was a fairly arbitrary boundary.

On the basis of detailed stratigraphic and paleontologic studies, Cullison (1944) redefined the Jefferson City formation of Missouri, raised it to a group, and divided it into two formations-the Theodosia formation above and the Rich Fountain formation below. He discussed the relationship of the Jefferson City group to the overlying Cotter dolomite and described and figured many of the fossils characteristic of each of these formations, adding materially to our knowledge of these units in their type region. His conclusions, however, have not been adopted by either the Missouri or the U. S. Geological Surveys.

Although the Kingsport limestone is faunally equivalent to a part of the Jefferson City, there is still uncertainty and much difference of opinion as to exactly what is contained within the limits of the Jefferson City in Missouri.

The other older name, Forked Deer formation, was taken from Forked Deer Creek at the Thorn Hill section and was used only as a heading for a group of descriptions of individual strata in that section (Hall and Amick, 1934, p. 205). No attempt was made to define it as a formation or to give any account of its geographic or regional correlation. It was never formally adopted by the Tennessee Division of Geology and has never been used outside the original publication. In the meantime Oder's name Kingsport limestone was adopted informally by the various mining companies and formally by the State Division of Geology and the U. S. Geological Survey, and it is now well established in geologic literature.

The name Kingsport limestone was first published without description on several strategic mineral maps issued during and after the Second World War (Rodgers, 1943; Dunlap and Rodgers, 1945; Kent, Rodgers, and others, 1945 ; Dunlap, 1947). The first description of the formation was by Oder and Miller (1945), but this applied only to mine sections in the Mascot-Jefferson City district. Subsequently the formation was briefly described by Miller and Fuller (1947) for southwestern Virginia and by Rodgers and Kent (1948, p. 25-26) for the Thorn Hill and Lee Valley sections, but the present report contains the first description of the type section.

\section{IIMITS}

As here defined, the Kingsport limertone includes units 459 to 519 (lower 3 feet, 3 inches) of the Thorn Hill section (Hall and Amick, 1934, p. 205-208) and units 240 to 256 of the Lee Valley section (Rodgers and Kent, 1948, p. 25-27). The contacts in the Thorn Hill section are those originally selected by Oder and the writer about 1937 and subsequently used by the writer in revising the map of the Mascot-Jefferson City district. The base of the formation is drawn at the bottom of a thick unit of aphanitic sublithogr?phic "dove"colored limestone with thin crinkly shale partings; the top is drawn at the base of a thin but persistent sandstone whose grains are cemented with white chert-the chart-matrix sandstone of Oder, who discovered this valuable key bed. There are actually two or three chertcemented sandstone layers in most sections examined; the one here used, however, occurs at the top of a finegrained dolomite bed forming the lower part of unit 519 at Thorn Hill and unit 257 at Lee Valley. What is believed to be this same sandstone is well exposed in unit 68 in the type section of the Kings?ort limestone on U. S. Highway 23 (p. 51) and at many localities in the Mascot-Jefferson City district and elsewhere.

The boundaries of the Kingsport limastone as here drawn are not exactly the same as those of the Jefferson City formation of Oder or of the Forked Deer formation of Hall and Amick. Furthermore, the lower limit does not agree with the lower limit of the Kingsport limestone as now drawn by Oder and his associates (Oder and Miller, 1945; Allen, 1947, 194ع). In naming the Kingsport limestone, Oder and Miller $(1945$, p. 1) stated that the names Kingsport and Mascot had been selected by Oder and Bridge for use in their forthcoming reports on the Knox dolomite of East Tennessee. In their paper, the stratigraphic sections as developed in the mines at Mascot, New Market, and Jefferson City are described in considerable detail, and the characters and importance of a number of marker beds useful in subsurface correlation are thoroughly discussed; no attempt is made, however, to correlate this information with surface data, although residual materials from many of the marker beds have been found to be extremely useful in surface mapping. The top of the formation is placed at the base of the chert-matrix sandstone (Oder and Miller, 1945 , p. 5), but no mention is made of the contact with the Longviev dolomite beneath; in fact, one gets the impression on reading the paper that all the sections end below within the Kingsport. This is still Oder's opinion, but other workers including the writer now place the base of the formation at the "zero bed" in Oder and Miller's I Lascot section, at the -66 bed in their New Market section, and some- 
where in the 10-3 (T) bed in their Jefferson City section, for these beds are believed to correspond almost exactly to the base of the Kingsport limestone in the Thorn Hill and Lee Valley sections (Rodgers and Kent, 1948, p. 25-26; Brokaw, oral communication, 1950) and to the base of the formation as exposed in the type section on U. S. Highway 23.

The type section of the Kingsport limestone is on the east side of U. S. Highway 23 just northwest of Kingsport (pl. $3 E$ ). The top of the formation is 0.55 mile north of the traffic light at the intersection of U. S. Highways 23 and $11-W$; the base is 0.23 mile farther north. The section of the Kingsport proper was measured by Oder and the writer in 1940; the other details have been added by the writer on subsequent visits. The area is shown on plate $3 E$.

Section of the Kingsport limestone and associated formations on U. S. Highway 23 north of the junction with U. S. Highway 11-W, Kingsport quadrangle, Tennessee ( $p l .3 E$ )

[Units 68-85 measured by Josiah Bridge, 1951]

The contact of the Mosheim member of the Lenoir limestone and the Mascot dolomite crosses the highway about 0.15 mile north of the intersection and passes northeastward to the north of the school. It is not well exposed but is marked by a sudden break in topography and by a line of shallow sinks.

Between this point and the entrance to the Kingsport cemetery 0.45 mile north of the intersection, the section is largely covered, but scattered outcrops of Mascot dolomite appear in the fields along the east side of the highway. Specimens of Ceratopea keithi Ulrich and Orospira sp., both characteristic Mascot fossils, were found in the dolomites about $80 \mathrm{ft}$ stratigraphically above the base of the formation.

Section begins at the top of the continuous outcrops near the powerline pole north of the cemetery entrance.

Mascot dolomite:

85. Dolomite, fine-grained; light gray on freshly broken surfaces, darker on weathered surfaces

84. Dolomite, similar to unit 85 but with thin layers of chert, chert nodules, and small siliceous geodes

83. Dolomite, similar to unit 84. Two beds, each about 9 in. thick

82. Dolomite, similar to unit 83 , with many thin (half-inch to two-inch) chert layers, and with layers of small chert nodules and geodes near the top of the unit. The chert nodules are smooth, rounded, light gray to white on fresh surfaces, rusty tan on weathered surfaces. The geodes resemble small cauliflower heads averaging less than 1 in. across, rusty red on the outside, and filled with small clear quartz crystals

81. Dolomite, like unit 82 , but no chert; a single layer

80. Dolomite, like unit 82 , but no chert; a single layer.
Mascot dolomite-Continued

Feet inches

79. Chert, brittle; china white on fresh surfaces, rusty on weathered surfaces, banded and brecciated.

78. Dolomite, fine-grained, well-bedded; light bluish gray on freshly broken surfaces, dull gray on weathered surfaces. Many layers of small ovoid chert nodules, most of them 1 in. or less across, but with some as much as 2 in. Chert is light gray on freshly broken surfaces but rusty orange on the outside rind where weathered. Some layers of small siliceous geodes similar to those in unit 82. A powerline pole is opposite this exposure

77. Chert, brittle, white, porcellaneous; bluish white and semitranslucent where fresh, dead white with yellow stains where weathered

76. Dolomite, similar to unit 78 , with many scattered ovoid chert nodules (mostly less than 1 in. across) and with one or two layers of larger flat chert nodules_-

75. Chert, like unit $\mathbf{7 7}$

74. Dolomite, similar to units 76 and 78 , wellbedded; individual beds from 8 in. to 3 ft thick, a few thin bands of chert nodules

73. Dolomite, similar to unit $\mathbf{7 4}$, a single thick bed with widely spaced layers of small chert nodules (less than 1 in. across) arranged along incipient irregular poorly developed bedding planes

72. Dolomite, fine-grained, well-bedded, lightbluish-gray, similar to unit 78 , a single bed. Contains a few scattered chert nodules

71. Dolomite, like unit $\mathbf{7 2}$

70. Dolomite, fine-grained, light-bluish-gray ; weathering yellowish gray to dull gray. Contains from 6 to 8 bands of small ovoid chert nodules, most of them less than 1 in. across

69. Dolomite, like unit 70 with conspicuous band of chert nodules from 1 to 2 in. across, 9 in. above the base. Several thin bands of chert nodules less than 1 in. across in the upper 9 in

68. Dolomite, gray, fine-grained, almost pure at the top but becoming arenaceous below. The sand grains are well rounded, frosted, increasing in abundance toward the base of the unit; the lower 3 to 4 in. are almost pure sand cemented by chert, forming a chertmatrix sandstone. This sandstone is hard and white in fresh exposures, becoming rusty and crumbly in weathered pieces

Thickness, measured part of Mascot dolomite 
The total thickness of the Mascot dolomite in this section is calculated as either 545 or $670 \mathrm{ft}$, assuming uniform dips of 20 and 25 degrees, respectively. The larger figure is probably more nearly correct.

[Units 1-67 measured by C. R. L. Oder and Josiah Bridge, 1940]

Kingsport limestone:

67. Dolomite, fine-grained, light-gray, wellbedded with very little chert; unit partly covered

66. Chert layers, almost continuous, white, stained with yellow and orange, thick and nodular

65. Dolomite, fine-grained, light-gray, with scattered layers of flat ovoid chert nobules as much as 2 in. across and a few thin layers of white chert along bedding planes. A conspicuous layer at the top

64. Chert, dark-gray, with a sugary texture

63. Dolomite, fine-grained, light-gray, without chert

62. Dolomite, fine-grained, light-gray, witl thin chert layers in the base and siliceous rosettes or geodes in the upper part

61. Dolomite, like unit 62 , with thin slabby chert nodules, $1 \mathrm{in}$. thick and 8 to $10 \mathrm{in}$. long; also thin black shale partings...-.

60. Largely covered, probably dolomite with heavy white chert bands.

59. Dolomite, in part fine-grained, in part "recrystalline"

58. Covered interval

57. Chert, compact, white, ropy, in part conglomeratic and containing false oolite, fossiliferous

56. Largely covered; about $1 \mathrm{ft}$ of "recrystalline" dolomite at top

55. Limestone, blue, the lower inch coarsely "recrystalline," the remainder aphanitic.

54. Limestone, blue, aphanitic, no clay partings, with layer of black chert nodules at base

53. Dolomite, light-gray, fine-grained, with Ceratopea capuliformis Oder

52. Dolomite, with an irregular band of siliceous oolite (the $\mathrm{C}$ oolite of the Mascot geologists, $130 \mathrm{ft}$ below the top of the formation at Mascot)

51. Dolomite, fine-grained, light-gray

50. Limestone, very fine grained to aphanitic, light-blue; Ceratopea capuliformis Oder seen on upper surface.

49. Dolomite and limestone, most of the dolomite coarsely "recrystalline"

4\%. Chert, white, brittle, enclosed in gray very fine grained dolomite. Top and bottom surfaces brecciated; top fairly smooth, bottom with waffle-iron pattern
Feet inches

6

4
Kingsport limestone-Continued

47 Limestone, mostly fine-grained to arhanitic, light-blue; some beds near top coarsely "recrystalline"; fine-grained

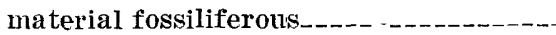

46. Nolomite, with thin bands of flat ovoid white chert nodules as much as 8 in. long. Upper 2 ft coarsely "recrystalline".

45. Limestone, thin-bedded, with some sl ale partings

44. Limestone, fine-grained to aphanitic, al out 1 in. of black chert at base

43. Limestone, blue, aphanitic to subcrystalline, with wavy very thin clay partings, subconchoidal fracture. The limestone weathers light blue; the clay partings weather to a chalky white and stand out in low relief. The "brown rock" of the Mascot district. Strike N. $60^{\circ}$ E., dip $20^{\circ} \mathrm{SE}$

42. Chert, ropy, porous, white, weathering to yellow

41. Shale, black, platy

40. Dolomite, fine-grained, light-gray, two beds

39. Limestone, like unit 43, thick-bed led, aphanitic to subrrystalline, fossilifer-

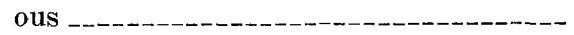

38. Clay, with flattened banded nodules of dead-white chert with black translusent streaks that weather vellow like chert of the Chepultepec dolomite

37. Limestone, like units 43 and 39 , tr ickbedded, aphanitic, fossiliferous_

36. Covered interval, much platy chert in the residual materials

35. Dolomite, light-gray, fine-grained...-.-.-

34. Limestone, like unit 43. A single bed 45 in. thick overlain by a 10-in. bed.....--

33. Shale parting

32. Limestone like unit 34, largely covered--

31. Covered interval, probably limestone (not recorded)

30. Limestone like unit 34 . Three massive beds exposed in small quarry

29. Covered interval, probably limestone-_---

28. Dolomite, coarsely "recrystalline," medium-gray, with pink rugs. A cast-iron pipe crosses this outcrop

27. Limestone, blue, aphanitic to subcrystalline, with thin crinkly shale parting: $\mathbf{s}_{--}$

26. Covered interval, probably limestone---_-

25. Chert, brittle, white, platy, with algal impressions on bedding planes, weathers yellowish on surface, oolitic and conglomeratic

24. Covered interval, mostly limestone

23. Limestone, like unit 27 , blue, aphanitic to subcrystalline

22. Covered interval, with limestone like unit 23 at base

Feet inches 4 10

4

5 3

4

1

2

6

8
0
0
7
6
0


8
0


6

4
0


Kingsport limestone-Continued

21. Dolomite, fine-grained, light-gray, with scattered vugs of pink dolomite, weathers buff to tan

20. Chert, brittle, white, platy, and laminated

19. Chert, rusty, porous, with many rectangular slots which may represent leached limestone pebbles. Fossiliferous, Hormotoma on upper surface

18. Dolomite, like unit 21

17. Limestone, blue, aphanitic to subcrystalline, with wavy clay partings, subconchoidal fracture. Weathers very light blue, the clay partings weather to chalky white and stand out in low relief, grades upward into unit 18

16. Dolomite, fine-grained, blue-gray

15. Limestone, similar to unit $\mathbf{1 7}$

14. Dolomite, very coarsely "recrystalline"

13. Covered interval, some outcrops of blue limestone like unit 15

12. Dolomite, in part fine-grained, in part coarsely "recrystalline." Some layers of chert nodules at the base and a few thin seams of chert

11. Dolomite, medium-gray, sandy and "recrystalline"; chert layer's at the base. Grades laterally down the dip into a tinegrained sandy limestone

10. Limestone, like unit 15 , with a drusy network of dolomite crystals and wavy green clay partings

9. Dolomite, light-gray, fine-grained, sandytextured, with several layers of ovoid chert nodules.

8. Shale, with ovoid chert nodules

7. Dolomite, like unit 9

6. Shale, greenish-gray

5. Limestone, like unit 15

4. Shale, parting, with platy chert

3. Limestone, blue, like unit $\mathbf{1 5}$

2. Dolomite, light-gray, coarsely "recrystalline"; grades locally into blue aphanitic limestone like unit 3

1. Dolomite, sandy-textured, fine-grained, light-bluish-gray. Weathers buff gray and locally to a rusty coarse sandstone. Two or three beds. Strike N. $55^{\circ}$ E., dip $20^{\circ} \mathrm{SE}$

Total Kingsport limestone

283

Longview dolomite:

Top $10 \mathrm{ft}$ massive, fine-grained, light-steel-gray, fine-grained dolomite. Some layers partly "recrystalline." Weathers cream colored. Overlies a massive chert bed.

Lower part of section not measured.

The Chepultepec and Longview dolomites are exposed to the north in a rather thickly settled area, and the contact between them could not be determined with certainty. About 0.7 mile north of the base of the Kingsport limestone are thick sandstones believed to mark the base of the Chepultepec; still farther north are fair exposures of the Copper Ridge dolomite. On the north face of the hill about 1.33 miles north of the base of the Kingsport, the contact between the Copper Ridge dolomite and the Maynardville limestone member of the Nolichucky shale is well exposed, and from Jere to the base of the hill the exposures are all Nolichucky shale.

Oder ( unpublished mimeographed notes, distributed during Kentucky Geological Society field trip in I Tay 1947 ) gives thicknesses of $346,1731 / 2$, and 605 feet for the Kingsport, Longview, and Chepultepec formations, respectively, in this section. Apparently he drew the base of the Kingsport 63 feet below the base as here described. These 63 feet should be added to the Longview dolomite, making its thickness in this section $2361 / 2$ feet.

\section{THICKNESS}

The Kingsport is about 280 feet thick in its type section along U. S. Highway 23 at Kingsport. It thins to the west, being but 218 feet thick in the Lee Valley section and 232 feet in the Thorn Hill section, both of which are in the Copper Ridge belt on the northwest side of Clinch Mountain. The formation beccmes thicker to the south; in the Mascot-Jefferson City district, Oder and Miller (1945) give thicknesses of 266, 306 , and 320 feet, respectively, for those beds in the mine sections at Mascot, New Market, and Jeffe"son City that are included in the Kingsport limestono by the present writer.

At Eve Mills in Monroe County southwest of Knoxville, approximately on strike southwest of the MascotJefferson City district, the formation averages 300 feet thick (Dunlap, 1947), but, to the southeast of Pays Mountain on the Mosheim anticline, it appears to have thinned to about 200 feet (Dunlap and Rodgers, $1 € 45$ ). According to Kent, Rodgers, and others (1945), the Kingsport limestone is about 250 feet thick in the Powell River area.

\section{BEDROCK IITHOLOGY}

The Kingsport limestone is composed of dolonite and limestone with subordinate amounts of shale, chert, siliceous oolite, and sand. The most abundant rock type is dolomite, but the most striking is the pure limestone, thick beds of which make up the bulk of the lower third to half of the formation; the limestone forms a conspicuous new element in the monotonous sequence of dolomitic strata that make up the formations of the Knox group.

The limestone is thick bedded ( 6 inches to 2 faet), compact, aphanitic, sublithographic, bluish gray to pinkish brown on freshly broken surfaces, bluish white to gray on clean weathered surfaces, breaking with a 
splintery to subconchoidal fracture. Some weathered surfaces show a thin white chalky rind. The limestone beds show rather closely spaced very thin irregular, wavy clay partings that are dark gray to black on fresh surfaces and weather tan to white and stand in low relief on weathered surfaces. The great bulk of the insoluble residues obtained from these limestones consists of thin flakes, representing fragments of these films. The limestones are the "brown rock" of the miners at Mascot, and the "dove limestones" of the miners at Jefferson City.

The dolomites are of two types: first, the very fine grained and light-colored variety that is common throughout the middle and upper parts of the Knox group, and second, a more coarsely crystalline granular gray and blue-gray variety. The latter, commonly called "recrystalline" in this district, is evidently a replacement of both the limestones and the fine-grained dolomites; the transition between the country rock and this coarse-grained phase may be seen at many places, both in surface exposures and in mine workings. No direct evidence bearing on the origin of the fine-grained dolomites can be cited; it is thought that they are also of secondary origin, but that they were formed at a much earlier time than the coarse-grained varieties.

Certain beds contain an abundance of small cavities, normally less than an inch in diameter, which have been filled or partly filled with calcite, dolomite, or milky quartz. The quartz fillings stand out in relief on weathered surfaces and are commonly found as sinall cauliflowerlike masses in the residual clays.

Chert occurs in several forms. Flattened nodules of light-gray compact chert occur in rows parallel to the bedding in certain layers and are so distinctive of particular layers that those layers can be recognized from one mine to another throughout the district. In addition, compact to finely porous white rusty-weathering chert occurs sparingly as layers in weathered exposures and abundantly as small blocks and chips in the red or orange residual clay derived from the dolomite and in the overlying soil.

A few thin layers consist of sandstone or of dolomite containing scattered rounded frosted sand grains; like the layers containing chert nodules, these sandy layers can be traced for miles even where the sand is confined to a layer an inch or two thick.

Detailed sections of the Kingsport limestone in the zinc mines of the district are given by Oder and Miller (1945, table 2).

\section{CORRELATION}

Fossils are more common in the Kingsport limestone than in the older formations of the Knox group, though still hardly abundant. They include the oldest species of the genus Ceratopea, $C$. capuliformis Oder, and also of several characteristic gastropods, notably Orospira.

The Kingsport limestone is shown by its fossils to be equivalent to the lower portion of the Newala limestone (Butts, 1926, p. 95-99) in southeastern Tennessee, northwestern Georgia, and northeasterm Alabama and to a portion of the Jonesboro limestone in the northeastern part of the Valley in East Tennessee where it is not possible to divide the Ordovician part of the Knox group into separate formations. It is also roughly equivalent to the Jefferson City of Missouri, but the exact correlation is not yet certain.

\section{MASCOT DOLOMITE}

NAME

The Mascot dolomite is named for the town of Mascot, Knox County, Tenn. The history of the name closely parallels that of the name Kingsport, and the reasons for preferring it to the older names CotterPowell beds (Oder, 1934) and Thorn Hill formation (Hall and Amick, 1934) are identical. The name first appeared on the geologic map of the Cc pper Ridge district (Rodgers, 1943) without description; it was subsequently published by Oder and MiJler (1945) and there credited to Oder and the writer. No description of the formation is contained in that paper, but several preliminary reports published as a result of the wartime investigations of the zinc deposits of East Tennessee contain brief descriptions of the formation and show its areal distribution in small areas.

\section{LIMITS AND THICKNESS}

The Mascot dolomite overlies the Kingsport limestone wherever the two have been recomnized. In turn it is overlain by limestone belonging to various Middle Ordovician formations; in the Mascot-Jefferson City district, the overlying unit is either the Mosheim member of the Lenoir limestone or more rarely the Lenoir limestone itself. The Mascot dolomite includes all beds from the upper 2 feet of unit 519 to that top of unit 687 in the Thorn Hill section (Hall and Amick, 1934, p. 208-214) and units 257 to 315 in the Lee Valley section (Rodgers and Kent, 1948, p. 27-32). No complete section is exposed in the vicinity of Mascot, but several partial sections are exposed nearby. The thickness at Thorn Hill is 520 feet 10 inches, and at Lee Valley 510 feet. In the Mascot-Jefferson City district, the formation may be as much as 600 feet thick. It is certain that the thickness varies considerably because of later erosion, which produced a pronounced disconformity at the top of the formation. 
BEDROCK LITHOLOGY

The Mascot consists chiefly of dolomite, similar to that in the Kingsport limestone, with chert layers, layers of chert nodules, and scattered beds of sandy dolomite that weather to rusty poorly cemented sandstones. Near the top in some sections, particularly in the Mascot-Jefferson City district, layers of aphanitic blue limestone are interbedded with the dolomites; these resemble the limestones of the Kingsport but lack, in the main, the thin clay partings. They also resemble the limestones of the overlying Mosheim member but in general lack the small clear calcite crystals that are so common in the Mosheim.

The chert of the Mascot is much like that of the Kingsport but is rather more abundant in the residuum over the lower part of the formation. The sandstone layers, especially close to the base of the formation, produce thin slabs and small blocks, which may also be found in the residuum over that part of the formation.

\section{CORRELATION}

Fossils, chiefly gastropods and cephalopods, serve to establish the general equivalence of the Mascot with the upper Newala limestone of Alabama, the uppermost Jonesboro limestone of northeast Tennessee, the Cotter dolomite (but not the Powell dolomite) of Missouri and Arkansas, and the Shakopee dolomite of the Upper Mississippi Valley region. Ceratopea is common, and the formation includes the zones of $C$. Keithi Ulrich and $C$. tennesseensis Oder in its lower part, and locally the zone of $C$. ankylosa Cullison close to the top (see p. 59).

\section{TOPOGRAPHIC EXPRESSION}

Areas underlain by the formations of the Knox group develop a characteristic topography that commonly is in sharp contrast to that developed on the underlying and overlying rocks. The details of this topography are beautifully shown on many of the new $71 / 2$-minute quadrangles of the TVA series, and elements of it can even be recognized on some of the old 30-minute quadrangles made a generation or more ago.

In general, this topography is characterized by moderate to gentle broad smoothly rounded slopes, without cliffs or abrupt changes of slope except along major streams. These characteristics are due, of course, to the homogeneous nature of the underlying rock. Although the area is well drained, the main drainage lines are widely spaced and commonly have gentle gradients, whereas the minor tributary valleys are shallow and also rather widely spaced. This again is due to the homogeneously resistant underlying rocks.
Belts underlain by these formations where ther have moderate to steep dips commonly rise above tha surrounding country as ridges of the second order, reaching approximately to the level of the so-called valley Floor or Harrisburg peneplain. They are about as high as the ridges developed on the Rome formation but are normally separated from those by a valley developed on the nonresistant Middle and lower Topper Cambrian rocks. The topographies of the two types of second-order ridges are entirely different: the ridges developed on the Rome formation are narrow, steep, intricately dissected, and commonly crit by closely spaced water and wind gaps; the Knox ridges are broader, with gentle slopes and few conspicuous gaps. Because of the nature of the underlying rocks and the sterility of the soils developed from them, Rome ridges are commonly forested, whereas Knox ridges are normally partly cleared and locall'r are farmed to their summits. Where associated with mountain ridges of the first order, such as Clinch Mountain (Avondale and Luttrell quadrangles), the second-order Knox ridges are separated from the firstorder ridge by a broad shallow high-level valley developed on the less resistant Middle Ordovician limestones and shales.

The same open rolling topography is found in areas where the strata of the Knox group are essentially horizontal, as, for example, over most of the Joppa quadrangle. The principal difference between the topography developed on the Knox group in this area ant that in the belts of steep dips, for example, the central part of the John Sevier quadrangle, is the dendritic drainage pattern and the absence of any conspicuous alinement of topographic features.

Where the formations of the Knox group dip at moderate to steep angles, it is often possible to recognize the approximate limit of the several formations from the topography alone. For example, on the Joln Sevier quadrangle, between the west edge of the map and Ellistown, the Copper Ridge dolomite forms a high continuous ridge along the northwestern side of the belt, the Longview dolomite forms a somewhat 1 igher and even more prominent ridge to the southeas', and the Chepultepec dolomite occupies a series of straight valleys and low saddles between.

The Kingsport and Mascot formations have less obvious topographic expression. The limestone in the lower part of the Kingsport may be recognized by a flat terrace or a series of saddles, commonly accompanied by sinks, developed on the southeast slope of the Longview ridge, whereas the somewhat more resistant lower part of the Mascot dolomite is indicated by the row of 
low inconspicuous knobs parallel to the Longview ridge and at a still greater distance from it.

This same sequence of topographic belts is even better shown on Copper Ridge in the western part of the Dutch Valley quadrangle, where the three ridges formed by the Copper Ridge, Longview, and lower Mascot dolomites and the strike valleys and sags developed on the Chepultepec and Kingsport formations are remarkably clear. Still farther northeast on Copper Ridge in the Avondale quadrangle, the ridges formed by the Copper Ridge and Longview dolomites unite to form a single high ridge on which the Chepultepec dolomite is represented by a break in slope which gives the effect of a broad terrace.

These are the normal aspects of the topography developed on the formations of the Knox group. There are also some surprising abnormalities. One of the most interesting of these is the band of sinkholes on the Talbott quadrangle southeast of U. S. Highway 11-E, between Rocktown Church and Alpha. This area of about 7 square miles is literally honeycombed with sinks of various sizes and depths, so much so that in the whole area there is virtually no surface drainage. At least three-fourths of the area is underlain by the Kingsport and Mascot formations. The explanation of this abnormal topography is that the area is a part of a belt of complex structure (p. 61-65) in which the Mascot dolomite has been crushed and broken by large and small faults and joints. This shattering together with the gentle sloping surface has favored the work of solution over that of normal surface erosion and produced the highly abnormal pitted plain shown on the map.

This general area is described by Safford (1869, p. 219) as follows:

There is an interesting platean of this formation [the Knox dolomite] in Jefferson County, between the Holston and the so-called Bay's Mountain, and extending from the vicinity of New Market to Russellville; these towns, and Morristown, being upon it. This area is from 300 to 400 feet above the Holston, and presents some excellent and extensive farming regions. A portion is called the New Market Valles, and is noted for its fertility. The rocks of this plateau, are at many points, but little inclined. They are, in reality, at the northern disappearing end of a synclinal trough.

Originally, the ridges of the Knox group were covered with a thick stand of hardwood timber, chiefly oak and hickory, and these were in sharp contrast to the pine-covered slopes of the ridges of the Rome. Much of this hardwood has been cut, and today the ridges are largely cultivated or used for pasture. Their soils, though stony, are among the best upland soils in the Valley, though like most soils derived from limestone they are commonly deficient in lime. The
American Zinc Co. has for years marketed the finely ground fresh tailings from its mills as agricultural limestone, and some of the best farms in the ajea have been consistently treated with this material.

\section{POST-KNOX FORMATIONS}

\section{THE NAME CHICKAMAUGA LIMESTONE}

The Chickamauga limestone was named by Hayes (1891, p. 142-144). The name replaced tl a term "blue limestone group" of Safford, the change being made in conformity with the practice of using geographic rather than lithologic names for formations. No type section was ever designated or described, but the name was taken from the area around South Chickamauga Creek in southeastern Tennessee and northwestern Georgia. As originally defined the formation included all limestone above the Knox dolomite and beneath the Sevier shale (which at that time was extended to include the Martinsburg and Reedsville shales), and in this sense it was used in all the folios of the southern Appalachian region, beginning with Hayes (1894) and ending with Butts (1910).

The Chickamauga limestone, as mapped in the folios, included the equivalents of the Kingsport and Mascot formations of this report in those areas in southeastern Tennessee, northwestern Georgia, and northeastern Alabama where they are represented by the Newala limestone (Butts and Gildersleeve, 1948, p. 19). With the close of the folio mapping in the Appalachian region the name Chickamauga fell into disuse, but it has recently been revived as a convenient general term by Rodgers (1953). In reviving the name, he has removed from it all beds known to be equivalent to strata of the Knox group, so that as now defined the unit includes limestone strata of Middle and Late Ordovician age. The unit is thinnest along the southeastern edge of the Valley where it represents a very short span of time; it is thickest in the sections near the Cumberland Plateau front where it represents practically all of Middle and Late Ordovician time.

About 1900 Ulrich began dividing the Chickamauga limestone into a number of formations. Some of these were described in the Revision of the Palezzoic Systems (Ulrich, 1911, pl. 27); others appeared only as names in correlation charts; and others were simply names used in notebooks and unpublished manuscripts. Only a few were ever adequately described, and still fewer have been mapped in detail over any considerable area.

In making these subdivisions Ulrich ras influenced by several ideas. He believed that sedimentation during this period took place in a number of parallel troughs, an idea he took from Safford (1869, p. 229-239) and greatly elaborated and expanded. He believed that 
these troughs were at times connected and at other times separate basins of sedimentation, and that some were dry or receiving terrestrial sediments while others were submerged. His units were based on specific faunas and lithology, for he had no concept of the lataral gradation of formations. These views seemed especially plausible because of the peculiar structural pattern of the region, for the formations in any structural belt may be quite different from those in adjoining belts, as a result of shortening by the thrusting of one belt over another.

Ulrich's general concept of the stratigraphy of the Chickamauga limestone is given in his Revision (Ulrich, 1911) ; later it was more fully elaborated by Butts (1928) and by Ulrich himself (1930). In general Ulrich believed that the strata included in the Chickamauga group consisted of a few widely distributed formations at the base, correlating with formations of Chazy age elsewhere; other widely distributed formations at the top, correlating with formations of Black River or later age elsewhere; and a great thickness of strata in between not equivalent to any formations elsewhere, the so-called Blount group, wedged in the middle between the Chazy and Black River beds (Butts, 1928, fig. 2). No complete section of the Blount group has ever been found, and at present the idea that such a unit exists, intermediate in age between the Chazy and Black River and represented only in the southern Appalachians, has been completely discarded.

The present theory is that there is a thick limestone sequence, the Chickamauga limestone, developed in the central and western parts of the Valley of East Tennessee and adjacent States, and that this grades laterally southeastward into a complementary shale and sandstone sequence, the Sevier shale and higher formations, developed along the southeastern side of the Valley. The two sequences intertongue in a central belt, and by the close of Middle Ordovician time shale deposition had lapped westward almost completely across the Valley. No complete statement of the details of Chickamauga stratigraphy can be given here, as they are in the course of being worked out by G. A. Cooper, B. N. Cooper, R. B. Neuman, and many others.

In the Mascot-Jefferson City district, the Chickamauga limestone-the Middle Ordovician limestone sequence-is made up of three units originally classed as separate formations. These are, in ascending order, the Mosheim limestone, the Lenoir limestone, and the Holston marble. These were all considered as distinct formations by Ulrich, Butts, and many others, including the writer, and are so shown on the map of the district published in 1945 (Bridge, 1945). The boundaries between them are rarely sharp and distinct, however, and the units commonly intergrade laterally. The Mosheim is best regarded as a member of the Lenoir limestone; it is considered separately below. Tho name Holston has been indiscriminately applied to the first marble (that is, coarsely crystalline pink or gray limestone that will take a polish) beds above the Lenoir in all parts of the Appalachian Valley, but it is by no means certain that all the beds so mapped reprosent a continuous unit, or that the top of the Lenoir loneath is everywhere the same. In fact, the preponder'nce of evidence would indicate otherwise.

The areas underlain by the Lenoir and Holston are normally characterized by gently rolling topography. Sinkholes are locally abundant, and in such places surface drainage lines are poorly developed. Cedar glades are practically limited to the outcrop of these limestones.

\section{UNCONFORMITY AT BASE OF LENOIR LIMESTONE}

The contact between the Knox group and tho overlying Middle Ordovician units in East Tennessee is marked by a surface of unconformity or, better, disconformity, which is inconspicuous at nany lonalities but which actually extends far beyond the boundaries of the State and marks one of the most widespread interruptions in deposition during Paleozoic time in eastern and central North America.

In general, throughout East Tennessee the uppermost formation of the Knox group is the Mascot dc'omite, and the writer knows of no place within the State where this formation has been completely removed $\mathrm{hy}$ preMiddle Ordovician erosion, though such places may exist. Such erosion has occurred locally, however, in Alabama, Georgia, and Virginia, and in those States Middle Ordovician rocks are known to rest on various older formations down to the Chepultepec dolomite-and possibly in Alabama even the Copper Ridge dolomite (Butts, 1926, p. 115, 117; Cooper, 1944, p. 33-34; Butts and Gildersleeve, 1948, p. 20). In other farts of Virginia, the reverse may be true, for fossils collected in Warm Springs Valley, near Healing Springs, suggest the presence of a Lower Ordovician formation of post-Mascot age. Similarly the Odenville limestone of Alabama (Butts, 1926, p. 99) appears to be Early Ordovician but post-Mascot.

Within the Mascot-Jefferson City district, the Mascot dolomite is overlain by the Mosheim member of the Lenoir limestone or, where this is locally wanting, by the typical Lenoir limestone itself. The contact is rarely well exposed, but it can commonly be located within a distance of a few feet. At most places, even where clearly exposed, it could easily be taken for a conformable contact. It is normally marked by an abrupt transition from dolomite beneath to linestone 
above, but the upper part of the Mascot dolomite may contain individual limestone beds as much as 6 feet thick, and at a few places these beds coalesce to make up the greater portion of the upper part of that formation. These limestones are lithologically similar to those in the overlying Mosheim member, and, where the two are in contact, the boundary may be difficult to locate. Often it can be located because abundant minute clear bits of calcite are present in the Mosheim but absent in the limestone in the Mascot. In other parts of East Tennessee the contact is further obscured by earthy dolomitic beds at the base of the Middle Ordovician, but these have not been found in the MascotJefferson City district.

A fair section across the contact is exposed on the south side of the 1,240-foot knob 0.8 mile southeast of Hodges Station in the New Market quadrangle. Here the upper beds of the Mascot dolomite are dominantly limestone and seemingly grade upward into the lithologically similar beds assigned to the Mosheim member of the Lenoir limestone. The chief distinction here is the presence or absence of the small clear calcite crystals believed to characterize the Mosheim.

A few localities show definite evidence of unconformity. At the mouth of Legg Creek in the John Sevier quadrangle, just west of McMillan Station between the Southern Railway and the Holston River, small outcrops of the basal limestone of the Mosheim member containing angular fragments of chert as much as 2 inches in diameter, clearly derived from the weathering of the Mascot dolomite, are exposed in the bed of the creek. The top of the Mascot dolomite is also exposed a few feet farther upstream, though the actual contact was not observed.

The contact is cleanly exposed in a cut on the Mascot road, at the crest of the slope about 0.65 mile west of the underpass beneath the Southern Railway about 1 mile west of Strawberry Plains, in the Mascot quadrangle. Slight irregularities in the contact can be detected, and the lower beds of the Mosheim member contain a conglomerate composed chiefly of small pebbles and fragments of dolomite, most of them less than 0.5 inch in diameter.

Chert conglomerate in the base of the Mosheim member, just like that found at McMillan Station, is exposed in the bed of a small tributary of Lewis Branch where it crosses the county road 1.5 miles north of the intersection of this road with old U.S. Highway 11-E just west of Friends Station, in the northwestern part of the New Market quadrangle.

A fourth locality for basal conglomerate was uncovered during construction of the new U. S. Highway
$11-\mathrm{E}^{22}$ about 0.6 mile southwest of its intersection with the road leading south from Friends Station. The exposure is in the ditch on the south side of the highway, 0.15 mile south of BM TGS 112 (1,033 fent), and consists of a deep-red hematitic clay containing small pebbles and fragments of chert. The actual contact is not exposed, but Mascot dolomite dipping gently southeast is exposed in the fields north of the lighway, and conglomeratic red and gray limestone in the Mosheim member is exposed at the base of the hill just south of the highway. The sequence is normal and there is no doubt of the position of the conglomerate.

These are the most conspicuous examples that were found during the detailed mapping of the district; doubtless there are others that were overlooked.

The most striking physical evidence of this unconformity in East Tennessee has been found at Douglas Lake, about 10 miles south of the Mascot-Jefferson City district. During the construction of the dam, an Ordovician sinkhole, 60 by 90 feet in plan and 150 feet deep, was encountered. This sink was filled with volcanic ash and shaly dolomite unlike any other rock in the region (Laurence, 1944; Caster, 1944). The contact of the Mascot dolomite and the Lenoir limestone is well exposed along the north shore of the reservoir at low stages of the lake (Bridge, 1955). In an area about a mile long, the relief on the surfacs of the Mascot dolomite measures at least 140 feet. There are also two sinks, each about 50 feet deep, filled in part by debris from the Mascot dolomite. This old surface is generally covered by impure dark-gray to black dolomite, locally as much as 50 feet thick, that grades upward into typical, nodular Lenoir limestone. In places the dolomite is absent, but, where present, it fills channels, sinks, and solution cavities along jcint and bedding planes in the Mascot dolomite, some of which extend to depths of 50 to 60 feet below the old surface. The lower beds are conglomeratic, containing angular and rounded bits of chert and dolomite and weathered chert nodules, all derived from the weatl sring of the Mascot dolomite, in a matrix of fine-grained dolomite. The conglomerate is thickest and coarsest in the large depressions on the upper surface of the Mascot dolomite; it becomes fine grained and thins to extinction on the intervening high areas. Where the dolomite is absent and the basal beds of the characteristic nodular Lenoir limestone overlap onto the Masiot dolomite, they are also finely conglomeratic; elsewhere within this area no conglomerate was seen above the dolomite.

22 In 1950, U. S. Highway 11-E was completely rel cated, beginning 0.5 mile west of the junction of the old highway with $U$. S. Highway 70 on the Mascot quadrangle and extending eastward across the remainder of the mapped area. 
Filled channels on the eroded surface of the Mascot dolomite have been mapped and discussed by Rodgers (1943) and Rodgers and Kent (1948, p. 32) on the south side of Copper Ridge, Grainger and Hancock Counties. One of these, near Shiloh School (Pressmens Home quadrangle), indicates a relief of nearly 200 feet on the surface of the Mascot dolomite. What are believed to be similar occurrences have been mentioned by Keith $(1901$, p. $2 ; 1905$, p. 8$)$ in East Tennessee, by Campbell (1894, p. 2) and by Cooper (1944, p. 33) in southwest Virginia, and by Munyan (1951, p. 54-59) in Georgia, but they have not been investigated by the writer. These widely scattered occurrences show that the disconformity extends throughout the region.

Within the Mascot-Jefferson City district there is also indirect evidence of unconformity, based entirely on the presence or absence of certain faunal zones. In the western part of the Mascot belt, Ceratopea ankylosa Cullison has been found at two localities, one near John Sevier Station, the other on the Mascot farm of the American Zinc Co. At the present writing (1953), it has been found only at two other localities in East Tennessee, one just north of Lickskillet in the Maynardville quadrangle, the other on the north shore of Douglas Lake in the western part of the area described above. At all four localities it occurs within a few feet of the top of the Mascot dolomite. At Douglas Lake the beds carrying this fossil are cut off by the unconformity, and this truncation can be clearly demonstrated.

Because of the intensive study that the Mascot-Jefferson City district has been given not only by the writer but by some of his associates on the Geological Survey and by geologists employed by the various zinc companies, the failure to find this fossil elsewhere within the area suggests very strongly that the beds carrying it were removed by erosion from most of the region before the deposition of the Middle Ordovician rocks.

\section{LENOIR LIMESTONE}

The Lenoir limestone was named by Safford and Killebrew (1876) from Lenoir City, Loudon County, Tenn.; the beds so named had previously been called the Blue or Maclurea limestone by Safford (1869, p. 232-233). Plate $3 F$ is a sketch map of the area around Lenoir City, based on a manuscript map prepared by J. C. Dunlap and P. P. Fox for the Geologic Division of the Tennessee Valley Authority, and kindly lent to the writer by Berlen C. Moneymaker, chief of the Division.
In the Mascot-Jefferson City district, the lower fart of the Lenoir limestone has been separately mapped as the Mosheim member.

\section{MOSHEIM MEMBER}

The Mosheim, considered in this report to be a brsal member of the Lenoir limestone, was named from M.osheim, a small village on the Southern Railway about 7 miles west of Greeneville, Greene County, Tenn. (Ulrich, 1911). No type section was ever published, but. in 1933 Ulrich took the writer to a cut on the Southorn Railway about 1 mile southwest of Mosheim and stated that the exposures in this cut were the type section. This area has been mapped by J. C. Dunlap (Dunlap and Rodgers, 1945), and the sketch map, plate $3 D$, has been compiled from his map with additions and details by the writer. At this locality, the beds strike N. $65^{\circ}-70^{\circ} \mathrm{E}$. and dip about $55^{\circ} \mathrm{SE}$. The strike of the railway cut is almost parallel to that of the beds, so that the belt of outcrop crosses the cut very gradually and the same units are exposed for long distances along its walls. The Middle Ordovician limestones are very thin at this point, measuring only about 180 feet across the outcrop from the base of the Athens shale to the top of the Mascot dolomite and having a calculated thickness of slightly less than 150 feet. Forming the basal member of the Athens shale is 30 to 35 feet of moderately crystalline compact dark-blue limestcne, which crops out in conspicuous ledges on the hills south of the railway cut and especially toward the western edge of the cut. This limestone is under]nin by 5 to 10 feet of thin irregularly bedded shaly notular blue limestone, which grades laterally into and is underlain in turn by 100 to 110 feet of thick-bedded very fine grained to aphanitic light-blue limestone, vell exposed along the south wall of the railway cut. "The base of this unit is concealed, but it evidently rests ujon a series of alternating fine-grained gray dolomites and fine-grained somewhat nodular blue limestones, which are exposed in the north wall of the cut. The comract crystalline limestones represent the Whitesburg limestone of Ulrich (1930, p. 2, footnote), the 5 to 10 feet of shaly nodular limestone appears to be typical Leroir limestone, and the massive aphanitic limestones are the Mosheim member, whereas the alternating dolomite and limestone beds represent the top of the Mascot dolomite. Strata near the base of the Athens shale are exposed in the road crossing the railway at the eastern end of the cut about 50 feet south of the tracks, and the compact limestone believed to represent the Whitesburg cross the cut about 300 feet west of this road crossing. No Mosheim appears on the north wall of the cut, the space where it should appear being covered. The ex- 
posures in the cut are about 0.25 mile long and the top of the Mascot apparently crosses the tracks about 0.4 mile west of the road crossing at the eastern end. To the west of the cut, the aphanitic limestone of the Mosheim intertongues with the typical nodular limestone of the Lenoir.

In the Mascot-Jefferson City district, the Mosheim member occurs in all three belts and commonly intervenes between the Mascot dolomite and the typical Lenoir limestone. Locally, however, it is absent-for example, in much of the area south of Friends Station and on the south side of the small knob of Mascot dolomite between the highway bridge and Mascot. In these areas it seems to have been overlapped by the typical Lenoir on an uneven surface of Mascot dolomite. Locally, as for example on the north side of this same knob, it is replaced by a crystalline limestome which at places is red and resembles the Holston marble.

At two other localities, both of them on the west side of the Strawberry Plains basin, coarsely crystalline red fossiliforous limestone, closely resembling the coarser and darker phases of the Holston marble, crops out where the Mosheim member should occur. The larger of these two areas begins in the woods just west of the American Limestone Co.'s quarry on Holston River just north of the Southern Railway bridge and extends in a southwesterly direction to within about 100 yards of the county road on the north side of the Holston River. The other outcrop is about a mile to the northwest, just west of the north-south road that connects the county road just mentioned with U. S. Highway 11-W. In both localities these beds rest on the Mascot dolomite and are overlain by typical nodular Lenoir limestene. Although the evidence is by no means conclusive, there is apparently a lateral gradation from typical aphanitic limestone of the Mosheim to red crystalline limestone in the woods west of the limestone quarry on Holston River.

At other localities coarsely crystalline limestone replacing the Mosheim is gray and resembles the basal beds in the type section of the Lenoir limestone at Lenoir City.

The distribution of the Mosheim member through the Appalachian Valley is at present uncertain. Ulrich (1911, p. 544) and Butts believed it to be widespread and they identified it in all belts from southeast to northwest and from Alabama far into Virginia. Actually they were applying the name Mosheim to the lowest fine grained lithographic limestone in the Middle Ordovician section. It is now known that the beds called Mosheim in the western belts are much younger than the true Mosheim of the central part of the Valley, and it is believed that the true Mosheim does not extend northwest of Clinch Mountain, but knowledge of its exact distribution will have to await tho results of detailed studies now in progress.

The Mosheim member is composed of thick-bedded very pure structureless light-pearl-gray or bluish-gray limestone, a typical lime-mudstone or calcilutite. It somewhat resembles the limestone of the Kingsport and Mascot formations, especially on weath red surfaces, but it lacks the crinkly shale partings that characterize the Kingsport limestone. In addition, the Mosheim is much bluer, locally almost black, although this dark phase is rare in the Mascot region. An additional peculiarity of the formation, and one which is a ready means of identification, is the abundance of very small crystals of clear calcite scattered through the aphanitic groundmass. The rock weathers to a deep-red clay and develops no chert. Weathered surfaces are either rounded or subpyramidal and are commonly radially fluted. This fluted weathering has also been seer on outcrops of the limestones in the Mascot and Kingsport formations, and it seems to be characteristic of the weathering of these aphanitic limestones.

\section{IENOIR LIMESTONE EXCLUSIVE OF MOSH 'IM MEMBER}

The typical limestone of the Lenoir is composed of thick- to thin-bedded irregularly bedded to nodular finegrained dark-blue to bluish-black limestone. Weathered surfaces are lighter bluish in color, and in weathering the rock commonly breaks up into small irregularly rounded nodules. The residual soils developed on the Lenoir limestone, including its Mo:heim member, are a deep maroon red, similar to those on the overlying Holston marble.

In the Mascot-Jefferson City distrist, the Lenoir limestone exclusive of the Mosheim member is rarely more than 250 feet thick.

The index fossil of the Lenoir limestone is the large gastropod Maclurites magnus Lesueur. In the MascotJefferson City district it is abundant st many localities, one of the best being the outcrops s.bout $31 / 2$ miles due south of New Market. Average specimens are 3 to 4 inches in diameter, but individuals as much as 8 inches across have been found. A number of smaller and less conspicuous gastropods are associated with Maclurites, and certain other beds are crowded with poorly preserved sponges.

[Bridge left no material describing the higher stratigraphic units of the Mascot-Jefferson City district-the Holston marble, the Tellico sandstone, and the Ottosee shale.] 


\section{STRUCTURE}

\section{APPALACHIAN VALLEY}

The major structural features of the Appalachian Valley have been described in many reports and only a brief discussion need be given here. The Valley in East Tennessee is a portion of a belt of faulted and folded Paleozoic rocks which extends from northern Alabama and Georgia through East Tennessee into Virginia and on to the northeast. The rocks exposed in the Valley range from Early Cambrian to early Pennsylvanian in age, and the proportion of rocks belonging to each period varies greatly in different parts of the Valley. Cambrian and Ordovician rocks predominate in the Valley in East Tennessee.

In East Tennessee the Valley is from 40 to 60 miles wide; it is bounded on the east by the major low-angle thrust faults of the Unaka and Great Smoky Mountains and on the west by the great east-facing escarpment of the Cumberland Plateau, beyond which the strata lie virtually flat. Its boundaries are thus determined by major structural features. Within the Valley itself, the outstanding structural features are a series of subparallel southeast-dipping thrust faults, which may be traced for long distances, and which divide the Valley into narrow, linear belts, each of which repeats, in general, the stratigraphic succession in the adjacent belts. The structure in most of these belts is homoclinal, and the prevailing dip is to the southeast. Anticlines and synclines are locally developed and may be the dominant structure in a given belt or portion of a belt, but in East Tennessee such structures are not as abundant as homoclines. Where developed, the axes of the anticlines and synclines are, in most places, roughly parallel to the thrust faults. This repetition of formational sequences of different degrees of resistance to erosion by folding and faulting is responsible for the peculiar and distinctive valley and ridge topography and the attendant trellis drainage that characterize the Appalachian Valley.

As noted above (p. 7, pl. 2), the Mascot-Jefferson City area includes three of these narrow, linear belts, here termed the Mascot, Jefferson City, and Shields Ridge belts. These belts strike northeast, and each extends beyond the limits of the area mapped. Each is a portion of a fault block that has been thrust out upon the block lying to the northwest of it. The faults forming the boundaries of these belts are here called (in order from northwest to southeast) the Saltville, ${ }^{23}$ Mill Spring, Rocky Valley, ${ }^{23}$ and Dumplin Valley faults.

${ }^{23}$ On the geologic map and sections published in 1945 (Bridge, 1945), the Saltville fault is called the Richland fault, and the Rocky Valley fault is called the Bays Mountain fault. See footnote, p. 6.

$339223-55-5$

\section{MASCOT BELT}

The Mascot belt is the northwesterly of the three belts. It is a portion of a major thrust slice that can be traced as a narrow continuous zone across the State. Beginning at the Tennessee-Georgia line this slice passes northward through Cleveland and swings northeasterly through Loudon, the northwestern portion of Knoxville, and Mascot. Throughout this entirs distance of about 110 miles it averages about 2.5 miles in width; the rocks are homoclinal, and dip to the southeast. A short distance east of Mascot the belt logins to widen, reaching a maximum width of about 8 miles in the area northwest of Jefferson City, changing from a homocline to a shallow syncline, pitching southwest. Northeast of Mooresburg (pl. 2) the belt again beromes liarrow but continues northeastward as a distinct structural unit at least to the Virginia-Tennessee lina. In this section the principal structure is again homoclinal with the prevailing dip to the southeast; there are, however, many minor structural irregularities.

Only that small portion of the Mascot belt extending from the northeastern city limits of Knoxville to the vicinity of Mill Spring is shown on the geologic map accompanying this report.

The northwestern edge of the Mascot belt is bo'unded by the trace of a major overthrust, which extends without interruption across the State. This is the Saltville fault, named for Saltville, Va., where it was ear'y recognized by Lesley $(1862$, p. 33) and named by Steronson $(1887$, p. 265). In the present study, this fault has been mapped only on the John Sevier quadrangle in the extreme western part of the area, between Loves Creek and Strong Creek, but its general course is shown on plate 2 and on the geologic map of the Maynardville folio (Keith, 1901). The average dip of the fault plane in the area mapped is about $40^{\circ}$ southeast.

Immediately northwest of the trace of the Saltville fault in this same general area are two small fault slices or slivers, which are clearly related to it. Only the southeastern one is shown on the accompanying map, but both are shown on the geologic map in the Maynardville folio (Keith, 1901). They are bounded along their northwest edges by small thrust faults that are presumably offshoots of the Saltville fault.

The southeastern fault diverges from the mair fault just west of Woods Creek and rejoins it between $S^{L}$ rong and Roseberry Creeks. The sliver included between this and the main thrust is a block of Nolichucky shale and the overlying Maynardville limestone member and not Knox dolomite as shown by Keith. ${ }^{24}$

24 On the 1945 map the dotted line connecting the northerr end of this fault with the main fault along the $05^{\prime}$ parallel is a print $r^{\prime}$ 's line used to delimit the color pattern and should have been removed before the edition was printed. 
The northwestern fault diverges from the Saltville fault about 2 miles west of Loves Creek and encircles the southeastern one. It encloses a block composed almost entirely of Copper Ridge dolomite. It was not mapped during this study, but its trace is believed to lie in the valley of Murphy Creek, and, according to Keith, it also rejoins or passes beneath the main Saltville thrust in the area between Strong and Roseberry Creeks.

The structure of the Mascot belt within the mapped area is comparatively simple. From Loves Creek at the western edge of the mapped area to Mascot, the belt is narrow and the strata strike N. $60^{\circ}-65^{\circ} \mathrm{E}$. and dip southeast, the average dip ranging from $50^{\circ}$ at Loves Creek to $25^{\circ}$ along Flat Creek at Mascot. The creeks that cross the belt between these limits expose the best and most complete sections of the Knox group within the mapped area.

Two tear faults displace the Maryville limestone along this belt near the west edge of the mapped area, and, though they have not been traced above the base of the Nolichucky shale, it is possible that the dolomite in the Knox group has been shattered in these areas by the same forces that produced the tear faults. It is noteworthy that both strike directly towards gaps in the topographic ridge underlain by the Copper Ridge dolomite. They also strike toward notches or gaps in the ridge to the northwest formed by the Rome formation; in fact, the one in the vicinity of Bethlehem Church may actually go through the gap. Both tear faults strike northwest obliquely to the strike of the rocks, and the southwest side of each has moved relatively northwest; in these respects they resemble many other tear faults in East Tennessee, for example, those in the Copper Ridge zinc district (Rodgers, 1943).

Near Mascot, the strike of the formations swings from N. $60^{\circ} \mathrm{E}$. to N. $35^{\circ} \mathrm{E}$. In the pre-Knox formations the swing is gradual, but in the formations of the Knox group, especially those near the top, the swing is fairly abrupt and forms a blunt anticlinal nose plunging southeast about a mile east of Mascot, close to the eastern end of the mine workings.

Northeast of Mascot the strike remains N. $35^{\circ} \mathrm{E}$. and the dip is $20^{\circ}$ to $30^{\circ} \mathrm{SE}$. as far as Richland (Ada on the Maynardville 30-minute quadrangle) ; no irregularities are known. Near Richland, however, the structure changes considerably. The formation from the Nolichucky shale down continue northeastward along Richland Valley with little change in strike or dip, but the formations above the Chepultepec swing abruptly east and southeast through $90^{\circ}$ around a synclinal mass of Ottosee shale centering in the unmapped area northeast of Strawberry Plains. This synclinal structure is here called the Strawberry Plains basin. Beyond this swing, the formations between the Ottosee and the Chepultepec strike about S. $65^{\circ}$ E. and dip $10^{\circ}$ to $25^{\circ} \mathrm{SW}$., until they pass beneath the Mill Spring fault that forms the northern edge of the Jefferson City belt.

Between these diverging strike belts, the intervening formations flatten out into a broad and shellow syncline in which few dips exceed $10^{\circ}$ and most arß less than $5^{\circ}$. This syncline contains some minor folds and small faults. It plunges gently southwest toward the Strawberry Plains basin of which it is the northeastern continuation. To the northeast it extends for some miles beyond the limits of the map. For the most part it includes nearly horizontal strata belonging to the Copper Ridge dolomite, though some of the higher hills, especially along the southeastern limb, are capped by remnants of the Chepultepec and Longviow dolomites.

\section{JEFFERSON CITY BELT}

The Jefferson City belt is part of a thrust slice that can be traced from Strawberry Plains rortheastward beyond the area mapped. To the southwest it seems to merge with the Mascot belt in the vicinity of Mascot, because of the dying out of the Mill Spring fault, which in this area forms the boundary between these two belts. The displacement along this fault diminishes in a southwesterly direction; the fault itself has not been traced beyond the general vicinity of Mascot.

The Mill Spring fault is named for Mill Spring, a small settlement in the southeastern part of the Joppa quadrangle, about 3 miles northwest of Jefferson City. It is a minor thrust fault which emerges from the eastern side of the Strawberry Plains basin ak out 1.25 miles north of East Hodges Station and has be^n traced in a northeasterly direction through Mill Spring to the northern edge of the map. It has not been traced beyond this point; it is believed to die out in the long, shallow syncline that forms the northeas' extension of the Strawberry Plains basin. The trace of this fault can be readily observed along both side of the road leading north from U. S. Highway 11-E to Nances Grove Church. The fault has not been rapped to the southwest across the central part of tha Strawberry Plains basin, because this structure is filled with a mass of structurally complex Ottosee shale, th? mapping of which was not a part of the project. In s.ll probability it does cross this unmapped area and connects with one of the faults shown emerging from the southwest side of the basin.

The surface evidence for the faults on the southwest side of the basin is well shown along both sides of the county road, about 1.5 miles east of Mascot, that connects the Mascot-Strawberry Plains road with U. S. 
Highway 11-W, along Holston River on the west side of Big Bend, and along the road in Big Bend. The general trend of the faults was established by these observations, and the projection to the southwest through the Mascot mine of at least the northern fault coincides, according to Harley M. Coy (personal communication, 1940 ), with zones of extensive shattering in the mine which have permitted extensive leakage in the past from both Big Flat and Roseberry Creeks. This fault may continue to the southwest beyond the mine and eventually die out in the thick mass of Lenoir limestone between Mascot and John Sevier.

None of these faults was recognized by Keith (1901) in his mapping of the Maynardville quadrangle, but the course of the Mill Spring thrust across the Strawberry Plains basin is indicated on his map by sharp zigzags in the formation boundaries on both sides of the basin.

The relatively straight traces of the faults in the area to the southwest of the Strawberry Plains basin would seem to indicate that the fault planes dip at comparatively steep angles. The small amount of offset of formation boundaries suggests that the amount of displacement is relatively slight (pl. 1, sections $E-E^{\prime}, F-F^{\prime}$ and $\left.G-G^{\prime}\right)$.

On the eastern side of the Strawberry Plains basin the fault plane dips at a much lower angle, as is shown on the map by the sinuous trace of the fault in the vicinity of the Nances Grove Church road. Further confirmation of the low dip of the fault plane in this area is to be found in the logs of certain drill holes put down many years ago by the American Zinc Co. According to M. H. Newman (personal communication, 1929), these holes were drilled in the fields adjacent to the road south from Nances Grove Church, about 0.25 mile south of the outcrop of the fault. They started in the Mascot dolomite and passed through the fault plane into Lenoir limestone within a few hundred feet of the surface.

For 3 to 4 miles northeast of a point about a mile east of the Nances Grove Church road, the trace of the Mill Spring fault is only approximately located. This is partly because of lack of outcrops and also partly because much of the area through which this portion of the fault passes has been under cultivation for many years, so that large quantities of the residual chert boulders have been removed from the fields by successive generations of farmers. Further evidence for the approximate position of the fault is found in the large blocks of sandstone, from high in the Copper Ridge dolomite, in cuts along the road 2.25 to 2.5 miles east of Nances Grove Church, and in the abundance of Copper Ridge residuum on the northwest slope of a wooded hill about 0.5 mile north of this point. Still farther northeast, in the vicinity of Mill Spring, the evidense for the fault becomes much more definite, and displacement of strata caused by it can be seen in the low bluff on the southwest side of Holston River about 1 mile northwest (downstream) of Cherokee Dam, and also in the riverbed when the water is low. At this point the fault plane dips steeply southeast and the displacement is small. Both of these features suggest that it is dying out to the northeast. Hence in this direction also the Jefferson City belt merges with the Mascot belt.

The structure of the Jefferson City belt is dominated by the large anticline lying just southeast of the Cherokee Dam, here called the Cherokee anticline. Tra axis of this fold strikes N. $40^{\circ}$ E. near the dam and extends in this direction for 10 miles or more to the northeast. The northeastern part of this fold lies beyord the boundaries of the map and was not studied in the preparation of this report. It is fairly well shown, however, by the mapping of the Cambrian formations on tr 9 geologic map of the Morristown folio (Keith, 1896). The axial part of this fold, including most of the exposures of the Nolichucky shale and all those of the formations beneath it, is now submerged beneath Cherokee Lake. To the southwest of Cherokee Dam the axis of the fold turns more nearly south, and the anticline plunges southward, passes between the towns of Jefferson City and New Market, and heads into the large reentrant in the trace of the Rocky Valley fault between 'T' 'mas and Koppick Knobs. Near the dam the dips on the flanks of the fold range from $15^{\circ}$ to $30^{\circ}$, but farther south the dip is much more gentle, rarely exceeding $10^{\circ}$ as each formation of the Knox group swings around the plunging nose of the anticline.

West of the south-plunging portion of the Charokee anticline is a broad, shallow syncline, plunging south past New Market beneath a large projecting mass of the Rocky Valley thrust block, and broken by minor faults parallel to the axis. On the west limb of this syncline the higher formations of the Knox group strike S. $70^{\circ} \mathrm{W}$. and dip gently south for 2 miles; then the strike swings northwest and north around an ant clinal nose until the rocks are cut off by the Mill Spring fault. This nose appears to represent the anticline out of which the Mill Spring fault developed.

Farther southwest, extending to and beyond strawberry Plains, is an area of complex structure lying between the Strawberry Plains basin and the Rocky Valley fault. This area has not been completely mapped because it involves chiefly beds younger than the Knox group and therefore was not relevant to the project. The structure of the narrow central part of 
this area, where the Strawberry Plains basin and the Rocky Valley fault come closest together, seems to be a succession of thrust slivers, but at the ends of the belt the structure is more open and includes two small domical uplifts: one in the Lower Bend of Holston River west of Strawberry Plains, the other between the valleys of Beaver Creek and Lost Creek south of East Hodges.

These domes, though minor, are among the most unusual structural features of the region. They do not seem to be directly related to any of the major structural features of the area but are a part of the highly irregular fold pattern developed in the Jefferson City block. Possibly they are complementary to the deep Strawberry Plains basin that lies just north of and between them, though it is presumably cut by the Mill Spring fault and more of it is on the Mascot block than on the Jefferson City block. The two domes expose strata of the upper Mascot dolomite in their centers and show gentle quaquaversal dips both in the Mascot and in the overlying and surrounding formations.

The western dome is elongated east and west, and its main crest is on the summit of a low grass-covered hill rising about 80 feet above the surrounding country and composed entirely of the Mascot dolomite. A minor crest about 0.75 mile to the east appears on the map to be larger than it actually is because of the Holston quarry excavated in its center.

The structural center of the East Hodges dome is eccentric to the area of outcrop of the Mascot dolomite and to the topography. It is about 0.5 mile due south of East Hodges in the northwest corner of the Mascot outcrop area. To the southeast is a hill more than 250 feet high composed of Mascot dolomite overlain by the Mosheim member and a small thickness of typical Lenoir limestone and capped by a small klippe of residual chert from the Copper Ridge dolomite, a remnant of the Rocky Valley fault.

Both domes clearly owe most of their present structural elevation to the major post-Pennsylvanian period of folding (p. 68), but the irregular wedging in and out of the encircling Mosheim member and the abrupt facies changes within it (p. 60) suggest that both domes may originally have been low hills formed during the erosion of the pre-Mosheim surface, standing slightly above the general level at the time of Mosheim and early Lenoir sedimentation, and that this slight relief may have been a significant factor in determining their later deformation.

The southeast flank of the Cherokee anticline exhibits several marked changes in the strike of the beds exposed along it. Between Lost Creek and the southern part of Jefferson City the strike of the Kingsport lime- stone averages N. $50^{\circ} \mathrm{E}$.; in the eastern part of Jefferson City it changes to an average of N. $20^{\circ}$ E.; and about 0.5 mile north of the Southern Railwny it swings back again to an average of N. $65^{\circ} \mathrm{E}$., close to the average regional strike.

In the area east of Jefferson City the Mrscot formation and the Lenoir formation (including the Mosheim member) are deformed in two tightly folded and faulted complex synclines. The axes of these folds trend approximately N. $60^{\circ}$ E., and the folds themselves are asymmetrical, the southeastern limb being the steeper, and in places overturned (pl. 1, sections $Q-Q^{\prime}$ and $R-R^{\prime}$ ). The faults associated with them are minor thrusts whose strikes roughly parallel the fold axes. They are best seen where they cut and offset the contacts between the different formations. They are difficult to locate and in fact may be entirely absorbed in the mass of tightly folded incompetent somewhat metamorphosed Lenoir limeston? that occupies the center of these synclines.

The western of the two synclinal masses shown on the map is bounded along its southeastern side by a small but well-defined thrust which dips steeply southeast. Although the trace of this fault has been located definitely only in that part of the area wher the Mascot is thrust onto the Lenoir, it is believed to extend a considerable distance in both directions. To the northeast it may connect with the fault shown cutting the Mascot dolomite just south of Talbott; to the routhwest it probably extends into the highly disturhed belt of Mascot in the valley of Mossy Creek and its most western tributary. North of this is a second stenply dipping thrust, presumably of smaller magnitude. This fault has been observed to cut all the contacts from the Lenoir to the Kingsport, and it may extend westward into the pits in the southern part of the old Mossy Creek mine. It is known that there are other small thrust faults in this area, but they are all of small displacement and it has not been possible to trace them into the formations of the Knox group.

In the valley of Mossy Creek and its north-flowing tributaries just east and southeast of Jefferson City is an area about 2 miles long and a mile wide of extremely complex structure that is related to and a continuation of the structure just described. This area is underlain by the Mascot dolomite, and within it the rocks have been strongly deformed and crumpled into a series of minor folds, none of which can be traced for any appreciable distance, and whose axes strike in vrrious directions. Many of the folds are roughly parallel to the regional strike, but others cut directly across it. Minor faulting undoubtedly accompanies this folding though no faults large enough to show on the map were found. 
Some exposures show obvious evidence of bedding slips. The uniform lithologic character of the rock and the lack of continuous exposures increase the difficulties of interpretation.

Most of these structural features are probably the result of crumpling in the synclinal trough between the Cherokee and Rocky Valley anticlines during the main period of deformation. Subsequently the area has been profoundly affected by solution, and it now has a welldeveloped subterranean drainage. The surface shows many sinks, and it is reasonable to assume that some of the aberrant dips are caused by recent slumping.

Traced toward the southwest the structure tends to become more regular and larger and to merge into a single strongly compressed and overturned syncline whose axis strikes about $\mathrm{N}$. $70^{\circ} \mathrm{E}$. This axis is well exposed on the crest of the ridge 0.6 mile north of the cross roads at Gravelly Hill. If the interpretation of structure given on p. 68-69 is correct, the overturned upper strata of the Mascot dolomite in this exposure could represent the lower part of the ruptured middle limb between this syncline and the Rocky Valley anticline.

Between this outcrop and State Highway 92, many oval flattened chert nodules of the type commonly found along bedding planes in the dolomite layers of the Mascot and Kingsport formations are strewn through the soil, especially in the cultivated fields. They have clearly weathered from the enclosing dolomites, and in this area almost all have been fractured by one or two sets of joints, and then have healed so that the nodule is as solid as ever. These joints are commonly normal to the long axes of the concretions, indicating that they are also normal to the bedding planes of the parent rock. The various parts of the nodules have been displaced in varying degree along these fractures, giving the effect of step faulting in miniature. In some the displacement is confined to a single fracture, in others it is spread through a zone of fractures, and in still others it is distributed over the entire nodule. Fractured nodules similar to those just described have been found in residual soils in other areas of intense deformation, notably on the sides of the valley south of the Athletic mine in the southeastern edge of Jefferson City. They have not been found in place in the unweathered rock.

Another area of complex structure lies in the center of Rocky Valley along and east of the New MarketPiedmont road, extending to and perhaps in part hidden under the Rocky Valley fault. This area is cut by a series of parallel thrust faults of small displacement into closely spaced slices, each one partly overlapping the slice immediately northwest, and each repeating parts of the upper Mascot dolomite and the Lenoir lime- stone, including its Mosheim member. Some of these faults were traced to the Rocky Valley fault under which they may disappear, whereas others were lost in the incompetent closely folded slightly metamorphosed homogeneous mass of the Lenoir. To the northeast they appear to die out in the more competent dolomites of the upper Mascot. They may, however, continue farther into the Mascot dolomite, and it is worthy of note that they trend toward and are in direct prolongation of the closely folded and faulted area near Jefferson City, described above. Surface mpping alone can hardly be expected to show whether the deformation is continuous between these two areas, for the uniform lithology of the Mascot dolomite and the lack of outcrops in the intervening area make the recognition of shatter zones and faults of small displacement difficult if not impossible.

The structure of the complex area in Rocky Valley is too complicated to be shown accurately on tr a scale of the map accompanying this report; therefore the fault pattern shown is to be regarded only as a generalization of the actual structure. In 1944 and 1945 . Kent, Brokaw, and others commenced detailed planetable mapping of this area and of part of the area east of Jefferson City and found many additional detrils too small to be shown here.

The several areas of complex structure just described strike toward one another and are alined along the southeast flank of the Cherokee anticline roughly parallel to the regional strike. Together they form a belt of generally synclinal structure in which the rocks are tightly compressed and intensely crushed and sliced, presumably because they lie just under the Rocly Valley thrust fault. This fault is nearly horizontal and probably originally passed not more than a few hundred feet over the whole belt of tight folding, which represents a zone of drag under it. The differ`nce in structure of the several areas reflects the differ $\urcorner$ nce in competence of the rocks involved.

Between the complex area in Rocky Valley and New Market, three more widely spaced faults, all trending northeast, displace the strata in the Jefferson City block and seem to pass beneath the Shields Ridge block. These faults appear to dip more steeply than those in Rocky Valley and may be strike-slip faults ins'ead of thrust faults. They are most easily recognized in the incompetent beds of the Lenoir limestone and seem to die out in the more resistant beds of the Mascot and Kingsport formations, but just north of New Market the northern fault displaces the chert-matrix sar dstone at the base of the Mascot dolomite 0.1 mile. Along the northern and southern faults, the block on the northwest appears to have moved relatively northeast; along 
the center fault the displacement is the opposite. Thus between the center and northern faults a narrow prism of sediments forming the axis of the shallow syncline already mentioned (p. 63) has been displaced southwest (or up) relative to the limbs.

A similar fault crosses U. S. Highway 11-E 0.5 mile east of East Hodges station, and may be seen in the railroad cuts and in the fields north of the highway.

\section{SHIELDS RIDGE BELT}

The Shields Ridge belt takes its name from Shields Ridge, a conspicuous ridge south of Jefferson City. The ridge is also locally called Bays Mountain (see footnote on p. 6). The belt begins as a distinct topographic and structural feature about 1 mile south of Morristown and extends southwestward across much of the mapped area to the area south of Strawberry Plains, beyond which its continuation is uncertain.

The northern boundary of the Shields Ridge belt is marked by the trace of the Rocky Valley fault, a lowangle thrust of considerable magnitude. The general course of this fault is shown on the geologic maps of the Morristown and Maynardville folios (Keith, 1896, 1901), but the present work has shown that it was incorrectly located in several places, especially east of Jefferson City. The generally low angle of dip $\left(3^{\circ}\right.$ to $5^{\circ}$ ) of the fault surface and the well-dissected topography make the fault trace very sinuous in the area between Koppick Knob and Strawberry Plains; in places on the hills southeast of U. S. Highway 11-E in the vicinity of East Hodges, small areas of the overthrust mass have been completely or almost completely separated from the main block, forming small klippen and semiklippen.

The map accompanying the Maynardville folio (Keith, 1901) shows the fault dying out to the west about 2 miles southwest of Strawberry Plains. Whether the fault actually terminates as shown by the folio, continues across the crumpled mass of Ottosee (Sevier) shale south of Mascot to join the fault passing through Knoxville in the extreme southwest corner of the area here mapped, or turns southward and joins a fault mapped in the folio south of Trentville and Wooddale, was not determined in the fieldwork for this report.

In tracing this fault for the Morristown folio (Keith, 1896, map), Keith was evidently misled by the breccias in the workings of the old Mossy Creek mine, for the fault is drawn north from Koppick Knob through the mine, and thence northeastward along the north face of Crockett Ridge for about 18 miles. The beds adjacent to this "fault" have been examined at a number of localities between Jefferson City and Morristown, and in all places a perfectly normal stratigraphic sequence has been found. Actually the trace of the fault plane turns eastward along the north face of Koppick Knob and has been traced in a northeasterly direction along the northwest slope of the ridge south of Mossy Creek to a point south of Talbott. Here the results of surface mapping have since been confirmed by drilling. Undoubtedly the fault continues in the direction of Morristown for a considerable distance.

On Koppick Knob itself the upper beds of the Nolichucky shale and its Maynardville limestc ne member rest on the Mascot dolomite. Traced eastrard in the valley of Lost Creek south of the knob, the I Lascot soon disappears beneath the floor of the valley, but the Cambrian formations are well exposed in the eroded center of the Rocky Valley anticline (p. 67) and extend eastward for about a mile, finally passing beneath the surface a few hundred feet west of the junction of the Rocky Valley road and State Highway 92 . This is the most easterly exposure of these formations in the Shields Ridge belt within the mapped ares.

The fault relation of the Maynardville to the Mascot is plainly demonstrated on the southwest slope of Koppick Knob on the hillside just east of the road fork 1.2 miles south of the Davis mine and 0.6 raile west of the knob. The lower part of this slope is a grassy pasture containing several small outcrops of Mascot dolomite. One of these is a small abandoned cuarry, now largely filled with trash. In 1929, on the vralls of this quarry, Ulrich, Butts, and the writer collected specimens of Ceratopea and a few other fossils characteristic of the Mascot dolomite. Scattered outcrops of the Mascot dolomite are found on the hillside above this quarry. In the woods just east of the secondary road these scattered exposures are replaced by almost continuous outcropping ledges to the summit of the low knob 0.25 mile west of the main summit. The lower ledges carry white chert and belong to the Mascot dolomite; they are succeeded above by a thick series of ribboned noncherty limestone belonging to the Maynardville limestone member. These upper beds dip gently north and northeast in conformit: with the structure of the Rocky Valley anticline. In this particular knob, the relation of the Maynardville to the Nolichucky shale is somewhat confused by the minor fault described on page 67 , and the rocks in these exposures have been correlated with the Lenoir limestone by some geologists, but mapping to the north and east shows that they occupy the normal position of the Maynardville limestone member and their lithology and fossils are characteristic of that unit.

For most of the distance between Koppic' Knob and the eastern edge of the mapped area the trace of the Rocky Valley fault lies between rocks of the Mascot 
dolomite in the Jefferson City block and rocks of all the units of the Knox group in regular succession in the Shields Ridge block, until near the eastern edge of the area the fault lies entirely within the Mascot dolomite. Locally, however, the beds below the fault are Lenoir limestone in one of the synclines described (p. 64). Throughout this stretch of the fault, there are very few outcrops above the fault in the Shields Ridge block, but outcrops of the Mascot dolomite are abundant at many localities in the underlying Jefferson City block. Over most of this distance the trace of the fault has been mapped chiefly on the character of the residual materials and on the general absence of outcrops in the Shields Ridge block, supplemented of course by the discordances in strikes and dips in those few limited areas in which outcrops are found. For example, in the area between Koppick Knob and the point where the fault trace crosses State Highway 92, at a place 0.3 mile north of Gravelly Hill and again on the hills northwest of Buffalo Grove Church, the trace of the fault is mapped almost entirely on the distribution of residual materials. Gravelly Hill itself was undoubtedly so named because of the thick accumulation on its summit of finely broken chert and sandstone blocks from the Copper Ridge dolomite.

About 0.6 mile due north of the crossroad at Gravelly Hill the Mascot dolomite is exposed in the axis of the tightly folded overturned syncline (p. 65). Less than 0.1 mile south of these extensive outcrops the north face of Gravelly Hill is completely mantled with thick Copper Ridge residuum in which no outcrops were found. The topographic relations here are such that, even with due allowance for creep in the residual materials, the nearly horizontal plane of the Rocky Valley thrust must have passed only a few tens of feet above the outcrops mentioned.

Similar relations were noted in the creek valley immediately east of Gravelly Hill and at other places between this valley and the eastern edge of the mapped area.

The southern boundary of the Shields Ridge belt is formed by another thrust fault, the Dumplin Valley fault, which begins southeast of Morristown and extends southwestward along or just northwest of Dumplin Valley. This fault marks in general the southeastern limit of the mapped area and was not studied in detail.

About 1 mile south of Mount Horeb, a small thrust either splits off or emerges from beneath the Dumplin Valley fault and extends northeastward approximately parallel to it for about 2.5 miles, dying out half a mile northwest of Mt. Vale Church, about 5 miles east of Jefferson City. The narrow sliver between it and the main Dumplin Valley fault repeats a part of the Mascot-Lenoir succession.

Just north of Piedmont at the western end of the mapped portion of the Dumplin Valley fault, a similar thrust fault encloses a block of Copper Ridge dolomite north of the main fault. South of this sliver, the structure of the area in the immediate vicinity of Piedmont is extremely complex and was not mapped for the present report; it involves chiefly the Cambrian formations older than the Knox group.

These small faults and the slivers they enclose are similar to those along the Saltville fault (p. 6).

The major structure of the Shields Ridge blo:k is anticlinal. The axis of the anticline strikes about $\mathrm{N}$. $70^{\circ} \mathrm{E}$. and lies just north of Shields Ridge, following in general the long dimension of Rocky Valley; it is here called the Rocky Valley anticline. The fold is strcngly asymmetrical; the northeast flank includes vertical and even overturned beds, especially to the west, whoreas the southeast flank is rather gentle and conforms to the general pattern of the homoclines in this rerion. The northwest flank of the anticline has been gratly eroded, and between Jefferson City and New Market erosion has cut back across the crest into the southeast flank, creating a great reentrant in the trace of the Rocky Valley fault that accommodates the plur ging end of the Cherokee anticline on the Jefferson City block. Farther west a lesser reentrant nearly surrounds the domical uplift on the Jefferson City block south of East Hodges.

At each end the Rocky Valley anticline plunges away from Rocky Valley. To the east it terminates in a simple nose which plunges northeast and can be traced as far as the eastern edge of the area mapped. The Copper Ridge dolomite swinging around the nose forms a conspicuous topographic feature when viewed from U. S. Highway 11-E or the hills farther north. A small fault, possibly a split from the main thrust fault. offsets the strata of the Maynardville and Copper Pidge on the west side of Koppick Knob. Aside from this minor fault and the downward truncation of the northeastern limb of the fold by the Rocky Valley faul', the northeastern end of the Rocky Valley anticline is a textbook example of a plunging anticlinal nose.

At the west end, the Rocky Valley anticline is double, the northern anticline being broken by a minor thrust fault that may be a split from the Rocky Valley fault. This anticline dies out a mile or so west cf the edge of the mapped area, but the southern anticline continues southwest as far as the south environs of Knoxville. 


\section{MECHANICS OF ROCK STRUCTURE}

The Mascot-Jefferson City district is unusual for the Appalachian Valley of East Tennessee. Although some parts of the district, notably the area west of Mascot, exhibit typical homoclinal thrust slices in which the rocks all strike northeast and dip southeast, most of it is characterized by more irregular structure with prominent anticlines and synclines whose axes strike in various directions, so that rocks strike northwest nearly as commonly as northeast and dip in all directions. There is no strictly comparable area anywhere else in the Valley of East Tennessee.

The district exhibits in general the typical structural asymmetry of the Appalachian Valley; that is, the thrust faults and the axial planes of the folds (whether broken by faults or not) dip to the southeast, but generally speaking the folds are more open than is normal in the Valley, and the entire area appears to have been less strongly compressed. The best example of an asymmetrical fold in this area is the Rocky Valley anticline (pl. 1, sections $B-H^{\prime}, K-K^{\prime}, L-L^{\prime}, M-M^{\prime}$ ). This asymmetry reflects the predominant horizontal force couple of the Appalachian orogeny: over to the northwest, under to the southeast. In the irregular structure of the Mascot-Jefferson City district, this couple was probably resolved in different directions in different parts of the area, but its impress is clear even in the most irregular and complex areas. Such a couple could presumably have been caused by an active orogenic force pushing northwestward in the upper layers of the earth's crust from the general vicinity of the present Atlantic Coastal Plain-under this assumption all the thrust faults in the area are overthrust faults-but there is no evidence in this district to prove or disprove the assumption.

The time of application of the forces must have been post-Mississippian, for just north of the mapped area the Saltville fault cuts Mississippian rocks. Elsewhere in East Tennessee, structures that are almost certainly of the same age cut Pennsylvanian rocks, and there is little doubt that the main structural features of the region were formed during or at the end of the Permian period in the Appalachian orogeny. There is no evidence in the district for more than one period of major deformation. The unconformity at the top of the Knox group represents, however, a period of widespread uplift and erosion and perhaps of gentle warping. It is possible that the sandstones close to the Cambrian-Ordovician boundary record a period of less pronounced uplift and warping in this or adjacent areas. Evidence outside the area studied in detail also suggests other periods of warping, one of the most conspicuous preceding the deposition of the Upper Devonian Chat- tanooga shale. The number of unconformities in the Mascot-Jefferson City district and, for trat matter, in East Tennessee, is, however, much fewer than has been advocated by some writers.

The combination of folds and thrust faults in the area makes it possible to suggest several stages in the process by which the typical thrust faults of East Tennessee developed out of folds (Willis, 1893, p. 269). It seems probable that the stresses that finally broke the rocks to form faults first caused the strata to buckle, the buckle in most cases taking the form of a pair of folds-an anticline to the southeast and a syncline to the northwest. The flank between the axes of each pair of folds, which is shared by them and commonly termed their "middle limb," dipped northwest and hence was in a weak position athwart the force couple, and here the break began. After the rocks had broken the fault grew by further movement along the fault surface rather than by an increase in the size of the folds. Thus the thrust fault grew at the expense of the folds, and where the process was carried to completion the remnants of the original folds are no longer evidentthe anticlinal axis and the upper part of the middle limb having been removed by erosion and the synclinal axis and the lower part of the middle limb having been buried beneath the thrust fault.

The first stage in this development may be exhibited by the fault in the valley of Blue Spring Branch north of Roderick Mountain at the west end of Rocky Valley (p1. 1, section $H-H^{\prime}$ ). Here the northern of the two anticlinal noses at the west end of the Rocky Valley anticline is broken by a small thrust farlt. The total movement is small and most of it was taken up by the fold rather than the fault.

Another stage may be shown by the Mill Spring fault northwest of Friends Station on the New Market quadrangle (pl. 1, sections $K-K^{\prime}$ and $L-L^{\prime}$ ). Near Lost Creek, an anticline lies just south of the frult and a syncline just north of it; these probably ar? remnants of the buckle out of which the fault developed. The total movement on either fold or fault is not great at this point, but most of the movement is now lopresented by the fault rather than the fold.

A further stage is excellently displayec'. by the Rocky Valley fault (pl. 1, sections $K-K^{\prime}$ to $Q-Q^{\prime}$; on the map published in 1945 the fault is called the Bays Mountain fault). Part of the original buckle from which the fault developed is represented by the Rocl y Valley anticline on the Shields Ridge block. The complementary syncline on the Jefferson City block is mostly buried beneath the overriding thrust block, but it appears to be represented by the belt of complex structure extending from east of Jefferson City southwest into Rocky Val- 
ley; its probable location is suggested on some of the cross sections ( $p l .1$, sections $P-P^{\prime}$ to $R-R^{\prime}$ ). The anticline, which originally lay southeast of the syncline, has been moved bodily until it rests on top of the syncline or even lies northwest of it. Where this has happened, the thrust surface beneath the anticline lies nearly horizontal, though southeast of the anticlinal axis it probably dips southeastward 20 or 30 degrees. In the area just east of Strawberry Plains, the fault surface also becomes steeper northwest of the horizontal portion, but in the vicinity of New Market and eastward this steep portion has been removed by erosion. Thus the movement of the Shields Ridge block on the Rocky Valley fault probably was in order: up, across, up. Where the Rocky Valley anticline plunges to the west (pl. 1, section $H-H^{\prime}$ ), and perhaps also where it plunges to the northeast (pl. 1, sections $Q-Q^{\prime}$ and $R-R^{\prime}$ ), the horizontal portion of the fault descends below ground level and probably narrows and disappears.

The final stage of fault development is exhibited within this area by the Saltville and Dumplin Valley faults and outside it by the majority of the thrust faults in the Valley of East Tennessee. Along these faults practically no traces remain of the anticline and syncline that were originally present; the crest of the anticline was presumably carried upwards and eroded away, the southeastern limb remains as a homocline, and the syncline is presumably buried. The slices along these faults appear to represent last remnants of the middle limb, caught and dragged along the fault surfaces.

It is of interest that the major faults in the district (the Saltville, Rocky Valley, and Dumplin Valley) all bring the Rome formation to the surface but that none of them cuts lower in the section. This same general rule holds for all the major faults in the Valley of East Tennessee, Virginia, and Alabama; only the great lowangle thrusts along the front of the Unaka and Great Smoky Mountains on the southeast side of the Valley reach into lower beds. Presumably the rule indicates that the lower beds of the Rome (beneath the thick sandstone beds) were incompetent and served as a gliding plane on which the sedimentary rocks of the Valley area tore loose from the crystalline basement when they were deformed into the present folds and fault slices. Possibly the lower Rome is the first such incompetent layer above the pre-Cambrian basement, for many of the pre-Rome sedimentary formations now exposed in the mountains southeast of the Valley may never have been deposited in the central and western parts of the Valley.

\section{ECONOMIC GENERALIZATIONS}

There is no evident structural explanation for the unusual geological character of the Mascot-Jefferson
City district, but perhaps it is more than a coincidence that this district, characterized by diverse and irre ?ular structure, should also be the most important zinc-mining district in the southeastern United States. Within the mapped area, the zinc deposits are confined to the $\mathbf{M}_{\text {ascot }}$ and Jefferson City belts, none being known south of the Rocky Valley fault. The Mascot belt contains the Mascot mine of the American Zinc Co. of Tennessee and a number of prospects; the Jefferson City belt contains the following mines that are either active or have been worked during the course of this investigation : Gresselli or New Market mine and Jarnagin mine of the A.merican Zinc Co., Davis mine and Athletic mine of the Tennessee Coal \& Iron Division, U. S. Steel Corp., and also a number of abandoned mines and prospects. The location of practically all the mines and prospects is shown on the accompanying map, and descriptions of most of them may be found in reports on the zinc deposits of East Tennessee (Purdue, 1912; Secrist, 1924; Brokaw, $1955)$.

A thorough investigation of the zinc deposits of East Tennessee was carried out by the U. S. Geolngical Survey in cooperation with the Tennessee Division of Geology during World War II. A number of proliminary maps and short reports were issued during the war, and final reports have either been puklished (Rodgers, 1948) or are in preparation (Brokaw, 1955).

The zinc in the district occurs partly as the sulfide sphalerite disseminated in the bedrock and partly as the carbonate smithsonite and the silicate hemimorphite (calamine) in irregular bodies scattered in the c verlying residual clay, commonly close to or again ${ }^{-1}$ the weathered surfaces of pinnacles of the bedrock. The oxidized (carbonate and silicate) deposits have resulted from the weathering of former upward extensions of the sulfide deposits. Practically every mine anc' prospect in the area was originally worked for oxidized ore, but all mining at present is for sphalerite. The ensuing remarks refer entirely to the sphalerite deposits and their relation to the stratigraphy and structure of the district.

The sphalerite in the district is a very pale honey yellow and is entirely free from appreciable amounts of galena, pyrite, barite, or fluorite; one or more of these characteristics distinguish the sulfide ore of this c'istrict from the ores of most of the other zinc districts in the southern Appalachians. Moreover all the mines and prospects within the mapped area occur in a cefinite stratigraphic zone not over 300 feet thick including the uppermost 50 feet or less of the Longview dolomite and the lower half or two-thirds of the Kingsport limistone. This zone consists largely of an alternation of limestone and dolomite, limestone predominating below and 
dolomite above. (See p. 47, 53.) The upper and lower boundaries of the ore-bearing zone vary somewhat in different areas but rarely transgress the limits given above (see Oder and Miller, 1945, table 2; as noted on p. 50, however, the Kingsport-Longview contact used in the present report corresponds to the "footwall sand" or "zero bed" of the Mascot section as given by Oder and Miller; see also Brokaw, 1955). Because the zinc deposits are restricted to this zone, prospecting and mining can be greatly aided by close attention to the stratigraphy ; for example, when prospecting is carried on by drilling, the drill holes can be aimed at the significant stratigraphic zone and can be bottomed as soon as this zone is passed.

The distribution of prospects illustrates this stratigraphic restriction. Thus in the belt I4 miles long between Mascot and Knoxville there has been a zinc prospect at practically every point where a stream crosses and exposes the lower part of the Kingsport, but at no other place in that area. Similarly there is a horseshoe of mines and prospects from New Market to Jefferson City where the outcrop belt of the Kingsport limestone swings around the southward plunging end of the Cherokee anticline.

Locally the ore-bearing zone is strongly brecciated, and in general it may be said that the stronger the brecciation, the larger the ore deposit is likely to be. There are exceptions, however; extensively brecciated areas may be entirely barren, and on the other hand very rich deposits of sphalerite have been found in places that are only slightly brecciated. The breccia ranges from crackle and mosaic types, in which the fragments are rudely oriented and the relations of adjacent fragments to one another are obvious, to breccias in which the disruption of the rock has been much more complete and no relationship is apparent between adjacent fragments. The fragments themselves range from minute particles to masses several feet across. In most areas they are composed of fine-grained dolomites of various colors, from light gray to black, the darker shades predominating. At a few localities, notably at the Grasselli mine, fragments of the dove limestones are abundant in the breccia, but they are not common elsewhere. The cementing material is white coarsely crystalline dolomite and pale sphalerite.

The brecciated bodies are very irregular in shape. Within this area they appear largely in the ore-bearing zone or in the overlying upper Kingsport and Mascot strata.

Another feature always present where ore is found, though by no means absent elsewhere, is granular coarsely crystalline dolomite, the so-called "recrystalline" (p. 47-54). This dolomite evidently replaced pre- existing limestone (and perhaps fine-grained dolomite) at about the time of brecciation and ore deposition (Oder and Miller, 1945, p. 3-4). The richest ore bodies in the district, though not necessarily the largest, are in this rock, whose regional distrik'tion is not greatly different from that of the breccia.

The origin of these breccias has been the subject of considerable controversy. The older workers (Keith, 1896, p. 5; Purdue, 1912, p. 27-28; Secrist, 1924, p. 104-105) were inclined to believe that the breccias lay along major thrusts, and Keith postuleted a major fault through the Mossy Creek mine on the evidence of the breccias there (p. 66). An alterrative theory, which also assumes that the breccias are caused by major displacements, postulates that they are produced by movement along large-scale bedding slips.

Ulrich (1931), on the other hand, interpreted the breccia at the Mossy Creek mine as a cave breccia and extended this explanation to all the other breccias in the area.

Oder and Hook (1950), following their colleague Odell, though accepting much of the krecciation as tectonic, ascribe some of it to the foundering of dolomite blocks into cavities formed by the solution of limestone by hydrothermal fluids.

The writer's interpretation, which he owes largely to - Currier (1935, also many informal discussions), is that the breccias are of tectonic origin, but that they are related to minor folds, faults, and bedding slips, especially local cross folds and cross faults, rather than to the major thrust faults of the region.

The outstanding objection to the first interpretation is that in no place are these breccias directly associated with the major thrust faults, and that in tead they are restricted to certain stratigraphic zones in relatively undisturbed areas.

The cave hypothesis was originally advanced by Ulrich to explain these two facts: restriction to a certain zone and lack of relation to major faults. In addition, the general appearance of the breccia in the pits of the Mossy Creek mine, where it has been somewhat weathered, lends support to the idea. The evidence against the cave hypothesis is best seen in fresh exposures, particularly in the mine workings, and may be summed up as follows:

1. Although the breccias may be sharply bounded above and below by bedding planes, thero is no definite border along the sides of the deposit which could be compared to the wall of the cave. On the contrary, the intensity of the brecciation diminishes laterally, passing by very gradual stages from rubble to mosaic, from mosaic to crackle, and from crackle into the unfractured rock. 
2. There is no evidence around the brecciated masses of the inward-dipping rim rock which is so characteristic of filled caves.

3. The brecciated fragments are clean and sharp and show no evidence of transportation.

4. The fragments are all derived from the strata peculiar to that part of the section, chiefly the finegrained dolomites and secondarily the interbedded limestones. There is no admixture of material from younger formations and no residual cherts, cave marble, or cave earth.

The statement by Ulrich (1931, p. 31) that "fossiliferous residual material of the Cotter [Mascot] formation has slumped down into the horizon of the Jefferson City [Kingsport] formation" is unquestionably true at certain places around the old Mossy Creek pits, but this slumping probably occurred during the present cycle of erosion and long after the formation of the breccias. It is an interesting and significant fact that no fossils have been found in place in the matrix of the breccias, though they have been found in the pinnacles of unbrecciated rock between the brecciated zones.

The breccias are clearly tectonic in origin and were presumably formed during the deformation of the region. They probably owe their stratigraphic distribution to differences in the competence of the strata. They are most common in that part of the section that consists of interbedded limestone and dolomite. The limestone is more plastic under deformation than the dolomite and tends to flow under forces that shatter the more brittle dolomite. Thus great numbers of joints cut the dolomite, but few cut the limestone in the same areas. The amount of fracturing suffered by the dolomite is naturally proportional to the amount of deformation which it has undergone, but the amount of displacement which individual fragments in the breccia have suffered depends in part on the relative competence of the different lithologic types involved, for the presence of beds of weaker more incompetent limestone allows a freer movement of the fragments of the more resistant dolomite beds than would occur were the entire mass homogeneous.

The geographic distribution of the breccias seems to indicate that they are closely related to the folding and faulting, for, although there is little or no brecciation along the major faults themselves, the heaviest brecciation seems to occur along the prolongation of faults that die out in a series of alternating dolomites and limestones. For example, in the vicinity of the Mascot mine, the Mill Spring fault zone dies out in strata of the Mascot and Kingsport formations, and a zone of brecciation extends in these strata from Mascot south- west to Knoxville. The amount of brecciation in this zone decreases generally to the southwest, though it is greater close to Legg and Woods Creeks, where the zone crosses the projection of the tear faults that cut the Cambrian rocks to the north. It is interesting and perhaps significant to note that although the Mascot belt can be traced as a distinct structural unit from Knoxville to the southern boundary of the State, and although it contains throughout this distance the same stratigraphic divisions of the Knox group, there are no zinc prospects (nor even barite prospects) in the belt from Knoxville to Cleveland. ${ }^{25}$ The published folio sheets and also local mapping in selected areas by others show no faults dying out in the Knox group of this belt in this distance.

Similarly the breccias exposed in the old Mossy Creek mine workings and those in the Davis mirs of the Tennessee Coal \& Iron Division, U. S. Steel Corp. lie southwest of the zone of complex small-scale tr rust faulting east of Jefferson City; the faults of that zone head toward the mines, one of them directly toward the Mossy Creek cut, where the brecciation is so well displayed. The brecciation in this area is not dirsctly connected with the Rocky Valley thrust to the soutl but rather with these minor faults in the Jefferson City block. No faulting was proved in other brecciated areas in the block.

It is also entirely possible that some of the brexciation in the region is related to minor longitudinal and transverse folding.

Breccias thus occur at many places in the district, especially where faults of small displacement enter the the ore-bearing zone, and zinc showings can be found in many of these places. Only a relatively few of these mineralized breccias contain minable zinc ore, however, and presumably some additional factor is responsible for the difference between ore-bearing breccias and barren or sparsely mineralized breccias. An examination of the geologic setting of the known major deposits in the district reveals that they lie not merely in areas where the Kingsport limestone is broken by minor faults of the sort that cause brecciation but exclusively in areas near marked changes of strike that outline anticlinal noses. Similar synclinal changos in strike are barren. Thus, around the Mascot mine the strike changes from N. $70^{\circ}$ E. along Roseberry Creek to N. $25^{\circ}$ E. north of the Mascot Rocks; yet the even sharper synclinal change in strike at Richland only 3 miles to the northeast is as far as known quite barren.

25 Secrist's map (1924) shows the Harwick mine (his no. 51) in this belt south of Cleveland, but the mine is actually located in the be't next to the west, a little north of Blue Spring. 
The group of mines from the Grasselli to the Jarnagin is draped in an almost continuous arc around the southplunging nose of the Cherokee anticline; at either end the belt of mines stops abruptly just short of synclinal changes in strike. As an empirical rule, therefore, it may be suggested that in this district commercial bodies of zinc ore are to be expected only where the Kingsport limestone is cut by faults of small displacement as it passes around the noses of anticlines.

To summarize, the following generalizations may be of value in future prospecting in the Mascot and Jefferson City belts:

1. The great bulk of the ore occurs in a zone about 250 feet thick centered in the lower part of the Kingsport limestone. (This does not apply to other zinc districts in the State; in each strike belt the ore appears to accupy a definite stratigraphic zone of limited vertical extent, but the zone is different from belt to belt. Occurrences are known in the Shady and Rome formations (Lower Cambrian), in the upper Honaker dolomite (Middle Cambrian), in the Nolichucky shale and especially in its Maynardville limestone member (Upper Cambrian), and in all the formations of the Knox group.)

2. The ore is commonly associated with extensive brecciation and the richest ore with secondary dolomitization. Areas that are not extensively brecciated, even though in the correct stratigraphic zone, are apt to be barren or at best only slightly mineralized.

3. The breccias do not occur along the major faults of the region but appear to be localized (a) in prolongation of faults that are dying out and (b) along minor folds, especially cross folds.

4. Breccias containing commercial zinc ore seem to be further restricted to the vicinity of marked anticlinal changes in strike.

Application of these generalizations to the district resulted during the war in recommendations for "wildcat" prospecting for zinc northwest and west of Friends Station, where the Kingsport limestone swings around the small anticline close to the Mill Spring fault, and on the dome exposing the Mascot dolomite south of East Hodges.

[Exploration by the American Zinc Co. of Tennessee in these two localities between 1946 and 1952 resulted in discovery of two major ore bodies. One is now in production, as the North Friends Station mine; the other is in the development stage (shaft sinking began in June 1953) as the Young mine. This is one of the most outstanding recent examples of ore discovery resulting from geologic prediction. Note contributed by Robert A. Laurence, July 1953.]

\section{LITERATURE CITED}

Allen, A. T., 1947, The Longview member of tr $\because$ Kingsport formation: Jour. Geology, v. 55, p. 412-419.

1948, Chert in the Kingsport formation $\varepsilon . t$ Mascot, Tenn. : Am. Inst. Min. Met. Eng. Tech. Pub. 2299 ; ibid., Trans. v. 178, p. 232-239.

Bassler, R. S., 1915, Bibliographic index of American Ordovician and Silurian fossils: U. S. Natl. Mus. Bull. 92, 2 v., $1521 \mathrm{p}$.

Bridge, Josiah, 1930, Geology of the Eminence and Cardareva quadrangles: Mo. Bur. Geology and Mines $2 d$ ser., v. 24, 228 p. [1931].

1945, Geologic map with stratigraphic sections of the Mascot-Jefferson City zinc mining dist:ict: Tenn. Div. Geology.

- 1955, Disconformity between Lower and Middle Ordovician series at Douglas Lake, Tenn.: Geol. Soc. America Bull., v. 66, p. 725-730.

Bridge, Josiah, and Cloud, P. E., Jr., 1947, Ner gastropods and trilobites critical in the correlation of Lower Ordovician rocks : Am. Jour. Sci., v. 245, p. 545-559.

Bridge, Josiah, Barnes, v. E., and Cloud, P. E., Jr., 1947, Stratigraphy of the Upper Cambrian, Llano uplift, Texas: Geol. Soc. America Bull., v. 58, p. 109-123.

Brokaw, A. L., 1955, Geology of the East Tennessee zinc deposits: U. S. Geol. Survey Prof. Paper [in preparation].

Butts, Charles, 1910, Description of the Birmingham quadrangle, Alabama: U. S. Geol. Survey Geol. Atlas, folio 175.

1926, The Paleozoic rocks, in Geology of Alabama: Ala. Geol. Survey Special Rept. 14, p. 41-230.

1927, Description of the Bessemer and Vandiver quadrangles: U. S. Geol. Survey Geol. Atlas, folio 221.

1928, Variations in Appalachian stretigraphy: Washington Acad. Sci. Jour., v. 18, p. 357-380.

- 1933, Geologic map of the Appalachian Valley of Virginia with explanatory text: Va. Geol. Survey Bull. 42, 56 p. - 1940a, Description of the Montevallo and Columbiana quadrangles: U. S. Geol. Survey Geol. At'as, folio 226.

1940b, Geology of the Appalachian Vølley in Virginia: Va. Geol. Survey Bull. 52 [1942].

1945, Description of the Hollidaysbure: and Huntington quadrangles [Pa.]: U. S. Geol. Survey Geol. Atlas, folio 227 [1946].

Butts, Charles, and Gildersleeve, Benjamin, 1948, Geology and mineral resources of the Paleozoic ar?a in northwest Georgia : Ga. Geol. Survey Bull. 54, 176 p.

Butts, Charles, and Moore, E. S., 1936, Geology and mineral resources of Bellefonte quadrangle, Pernsylvania: U. S. Geol. Survey Bull. 855, 111 p.

Butts, Charles, Swartz, F. M., and Willard. Bradford, 1939, Geology and mineral resources, Tyrone quadrangle [Pa.]: Pa. Geol. Survey 4th ser., Topog. and Geol. Atlas 96.

Campbell, M. R., 1894, Description of the Estillville shcet [Ky.Va.-Tenn.] : U. S. Geol. Survey Geol. Atlas, folio 12.

Caster, K. E., 1944, New synziphosuroid merostome from the Lower Ordovician [of Tenn.] [abst.] : Gool. Soc. America Bull., จ. 55, p. 1465-1466.

Cleland, H. F., 1900, The Calciferous of the Mohawk Valley: Bull. Am. Paleontology, v. 3, no. 13, 26 p. 1903, Further notes on the Calciferous' (Beekmantown). formation of the Mohawk Valley, with descriptions of new species: Bull. Am. Paleontology, v. 4, no. 18, 24 p. 
Cloud, P. E., Jr., 1948, Brachiopods from the Lower Ordovician of Texas: Harvard Coll. Mus. Comp. Zoology Bull., v. 100, p. 451-472.

Cloud, P. E., Jr., and Barnes, V. E., 1948, The Ellenburger group of central Texas: Tex. Univ. Bur. Econ. Geology Pub. 4621, $473 \mathrm{p}$.

Cooper, B. N., 1944, Geology and mineral resources of the Burkes Garden quadrangle, Virginia: Va. Geol. Survey Bull. 60, 299 p.

Cullison, J. S., 1944, The stratigraphy of some Lower Ordovician formations of the Ozark uplift: Mo. Univ. School Mines and Metallurgy Bull., Tech. Ser., v. 15, no. 2, 112 p.

Currier, L. W., 1935, Structural relations of southern Appalachian zinc deposits : Econ. Geology, v. 30, p. 260-286.

Dake, C. L., 1921, The problem of the St. Peter sandstone: Mo. Univ. School of Mines and Metallurgy Bull., Tech. Ser., v. 6 , no. 1,225 p.

- 1930, The geology of the Potosi and Edgehill quadrangles : Mo. Bur. Geology and Mines 2d ser., v. 23, 233 p. [1931].

Dake, C. L., and Bridge, Josiah, 1932, Faunal correlation of the Ellenburger limestone of Texas: Geol. Soc. America Bull., v. 43 , p. $725-741$.

Dunlap, J. C., 1947, The Eve Mills zine area, Monroe County, Tenn.: U. S. Geol. Survey Strategic Minerals Inv. Prelim. Rept. 3-215.

Dunlap, J. C., and Rodgers, John, 1945, Geologic map of the Mosheim anticline, Greene County, Tenn. : U. S. Geol. Survey Strategic Minerals Inv. Prelim. Map.

Gordon, C. H., 1918, Barite deposits of the Sweetwater district, East Tennessee: Tenn. Geol. Survey, Res. Tenn., v. 8, p. 48-82.

Gordon, C. H., and others, 1924, Marble deposits of East Tennessee: Tenn., Dept. Education, Div. Geology, Bull. 28, $264 \mathrm{p}$.

Grabau, A. W., 1937, Paleozoic formations in the light of the pulsation theory, v. 3, pt. 2 : Peking Univ. Press.

Hall, G. M., and Amick, H. C., 1934, The section on the west side of Clinch Mountain, Tenn.: Tenn. Acad. Sci. Jour., v. 9, p. 157-168, 195-220.

Hayes, C. W., 1891, The overthrust faults of the southern Appalachians: Geol. Soc. America Bull., v. 2, p. 141-152.

- 1894, Ringgold atlas sheet [Ga.-Tenn.]: U. S. Geol. Survey Geol. Atlas, folio 2.

Howell, B. F., and others, 1944, Correlation of the Cambrian formations of North America [Chart no. 1]: Geol. Soc. America Bull., v. 55, p. 993-1003.

Keith, Arthur, 1895, Description of the Knoxville sheet [Tenn.N. C.] : U. S. Geol. Survey Geol. Atlas, folio 16.

__ 1896, Description of the Morristown sheet [Tenn.] : U. S. Geol. Survey Geol. Atlas, folio 27.

1901, Description of the Maynardville quadrangle [Tenn.] : U. S. Geol. Atlas, folio 75 .

1905, Description of the Greeneville quadrangle [Tenn.N. C.] : U. S. Geol. Survey Geol. Atlas, folio 118.

Kent, D. F., Rodgers, John, and others, 1945, Areal and economic geology of the Powell River area, Claiborne and Union Counties, Tenn.: U. S. Geol. Survey Strategic Mineral Inv. Prelim. Map.

King, P. B., 1940, West Texas-New Mexico symposium, Part 1, Older rocks of Van Horn region, Texas: Am. Assoc. Petroleum Geologists Bull., v. 24, p. 143-156.

Knight, J. B., 1947, Some new Cambrian bellerophont gastropods : Smithsonian Misc. Coll., v. 106, no. 17, 11 p.
Laurence, R. A., 1944, An early Ordovician sinkhole deporit of volcanic ash and fossilferous sediments in East Tenne ${ }^{\text {rsee : }}$ Jour. Geology, v. 52, p. 235-249.

Lesley, J. P., 1862, On the coal formation of southern Virginia: Am. Philos. Soc. Proc., v. 9, p. 30-38.

Lochman, Christina, and Duncan, D. C., 1944, Early Upper Cambrian faunas of central Montana: Geol. Soc. America Special Paper 54, 181 p.

McQueen, H. S., 1931, Insoluble residues as a guide in stratigraphic studies: Mo. Bur. Geology and Mines Bienn. Rept. State Geologist [1929-30], p. 102-131 [preprint, 1930].

Miller, R. L., and Fuller, J. O., 1947, Geologic and structure contour map of the Rose Hill oil field, Lee County, Va.: U. S. Geol. Survey Oil and Gas Inv. Prelim. Map 76.

Moneymaker, B. C., Leonard, G. K., and others, 1949, Ge?logy and foundation treatment, Tennessee Valley Autrority projects: Tenn. Valley Authority Tech. Rept. 22.

Munyan, A. C., 1951, Geology and mineral resources of the Dalton quadrangle, Georgia-Tennessee: Ga. Geol. Survey Bull. $57,128 \mathrm{p}$.

Oder, C. R. L., 1934, Preliminary subdivision of the Knox dolomite in East Tennessee: Jour. Geology, v. 42, p. 469-4§7.

Oder, C. R. L., and Hook, J. W., 1950, Zinc deposits of the Southeastern States, in Snyder, F. E., ed., Symposium on mineral resources of the Southeastern United States, 1949 Proc., p. 72-87 : Knoxville, Univ. Tenn. Press.

Oder, C. R. L., and Miller, H. W., 1945, Stratigraphy of the Mascot-Jefferson City zinc district [Tenn.] : Am. Inst. Min. Met. Eng. Tech. Pub. 1818; ibid., Trans., v. 178, p. 22א-231, 1948.

Poulsen, Christian, 1937, On the Lower Ordivician faun"s of East Greenland; Meddelelser om Grönland, band 11 $、 \mathrm{Nr}$. 3 ; reprinted in Copenhagen Univ. Mus. minéralogie et géologie Commun. paléont. 57.

Purdue, A. H., 1912, The zinc deposits of northeastern Tennessee : Tenn. Geol. Survey Bull. 14, 69 p.

Purdue, A. H., and Miser, H. D., 1916, Description of the Erreka Springs and Harrison quadrangles [Ark.-Mo.] : U. S. Geol. Survey Geol. folio 202.

Resser, C. E., 1938, Cambrian system (restricted) of the southern Appalachians: Geol. Soc. America Special Paper 15, $140 \mathrm{p}$.

- 1942, Faunal content of the Maryville formation [Ala., Ga., Tenn.]: Smithsonian Misc. Coll., v. 101, no. 10, Pub. 3676.

Resser, C. E., and Howell, B. F., 1938, Lower Cambriar Olenellus zone of the Appalachians: Geol. Soc. America Bull., v. 49 , p. $195-248$.

Rodgers, John, 1943, Geologic map of Copper Ridge district, Hawkins, Hancock, and Grainger Counties, Tenn.: U. S. Geol. Survey Strategic Minerals Inv. Prelim. Map.

- 1948, Geology and mineral deposits of Bumpass Cove, Unicoi and Washington Counties, Tenn.: Tenn. Dept. Conserv., Div. Geology Bull. 54, 82 p.

- 1953, Geologic map of East Tennessee with explaratory text: Tenn. Dept. Conserv., Div. Geology Bull. 58, pt. 2, 168 p.

Rodgers, John, and Kent, D. F., 1948, Stratigraphic section at Lee Valley, Hawkins County, Tenn. : Tenn. Dept. Corserv., Div. Geology Bull. 55, 47 p.

Ross, R. J., Jr., 1951, Stratigraphy of the Garden City formation in northeastern Utah, and its trilobite faunas: Yale Univ. Peabody Mus. Nat. Hist. Bull. 6, 161 p. 
Safford, J. M., 1869, Geology of Tennessee : 550 p., Nashville. Safford, J. M., and Killebrew, J. B., 1876, The elementary geology of Tennessee: 255 p., Nashville.

Sardeson, F. W., 1896, The fauna of the Magnesian series : Minn. Acad. Nat. Sci. Bull., v. 4, p. 92-105.

Secrist, M. H., 1924, Zinc deposits of East Tennessee: Tenn. Dept. Education, Div. Geology Bull. 31, 165 p.

Sellards, E. H., 1932, The pre-Paleozoic and Paleozoic systems in Texas, in The geology of Texas, v. 1, Stratigraphy, p. 15-231 : Tex. Univ. Bur. Econ. Geology Bull. 3232 [1933].

Smith, E. A., 1876, Report of progress for 1875 : Ala. Geol. Survey, $220 \mathrm{p}$.

Stevenson, J. J., 1887, The faults of southwest Virginia: Am. Jour. Sci., 3d ser., v. 33, p. 262-270.

Stose, G. W., 1908, The Cambro-Ordovician limestones of the Appalachian Valley in southern Pennsylvania: Jour. Geology, v. 16, p. 698-714.

Trowbridge, A. C., and Atwater, G. I., 1934, Stratigraphic problems in the upper Mississippi Valley: Geol. Soc. America Bull., v. 45, p. 21-79.

Ulrich, E. O., 1911, Revision of the Paleozoic systems: Geol. Soc. America Bull., v. 22, p. 281-680; Index, v. 24, p. 625-668, 1913.
1930, Ordovician trilobites of the family Telephidae and concerned stratigraphic relations: U. S. I'ratl. Mus. Proc., v. 76, art. $21,101 \mathrm{p}$.

1931, Origin and stratigraphic horizon of the zinc ores of the Mascot district of East Tennessee [abst.] : Washington Acad. Sci. Jour., v. 21, p. 30-31.

Ulrich, E. O., and Cooper, G. A., 1938, Ozarkis n and Canadian Brachiopoda: Geol. Soc. America Special Paper 13, 323 p.

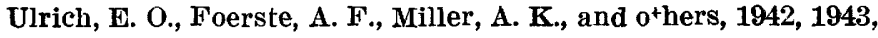
1944, Ozarkian and Canadian cephalopods: Geol. Soc. America Special Papers 37, 49, 58.

Walcott, C. D., 1916, Cambrian trilobites: Smithsonian Misc. Coll., v. 64 , p. 303-456.

Willis, Bailey, 1893, The mechanics of Appalarhian structure: U. S. Geol. Survey 13th Ann. Rept., pt. 2, p. 211-281.

Wilmarth, M. G., 1938, Lexicon of geologic names of the United States: U. S. Geol. Survey Bull. 896.

Wilson, J. L., 1949, Stratigraphy and faunal rel'tionships of the Upper Cambrian in the central Appalachians [abst.] : Geol. Soc. America Bull. v. 60, p. 1929-1930.

Winslow, Arthur, 1894, Lead and zinc deposits : Mo. Geol. Survey, v. 6, 7, $763 \mathrm{p}$.

Woodward, H. P., 1932, Geology and mineral resources of the Roanoke area, Virginia : Va. Geol. Survey Bull. 34, 172 p. 


\section{INDEX}

A

Acknowledgments.

American Zinc Co. of Tennessee

mines

A phelaspis zone, list of characteristic species.

Appalachian Valley, structural features.

B

Balk, Christina Lochman. See Lochman, Christina.

Bays Mountain

Bays Mountain fault

$6,56,66$

$7,61,68$

Bays Mountains

Butts, Charles, quoted

6,7
$70-71,72$

$70-71,72$

Canadian system of Ulrich

Cedaria zone, fauna

Chepultepec dolomite. correlation.

description

distribution of species........... 43-44

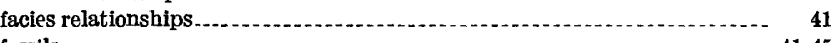

fossils..._.

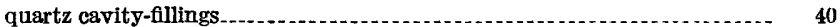

relation to Longview dolomite.

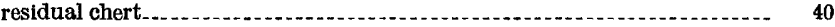

TVA quarry section

Chepultepec-Longview contact.

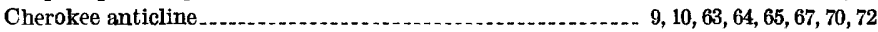

Cherokee Dam

Cherokee Lake

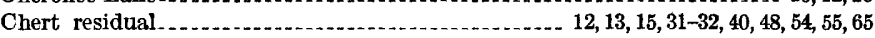

Chickamauga limestone, description

Clay, residual

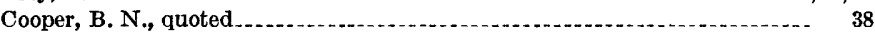

Copper Ridge dolomite

correlation

description ..................... 25-37

facies relationships......... $33-34$

fossils.

Loves Creek section

residual cheri........................... 31-32

Craig limestone member of Rogersville shale _..........

type section -

topographic expression

Crepicephalus zone, list of characteristic species

Cryptozoans

$32-33,40$

$\mathrm{D}$

Domes.

64,72

Douglas Lake

58,59

Drainage.

by Holston River

underground.

$6,56,65$

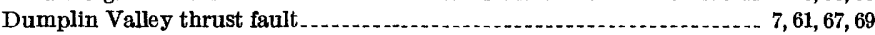

Duncan, D. C., quoted

F.

Faults

$61-66,68-69,71,72$

Faunal lists, Aphelaspis zone

Cedaria zone..

Crepicephalus zone

Longview dolomite.

Folds

Geography

G

6-7
H $\quad$ Page

Holston marble.

Jefferson City belt

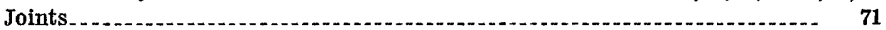

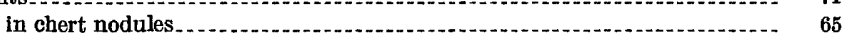

Kingspor limestone 1 Correlation

description. ...

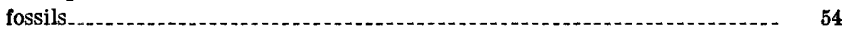

occurrence of ore

section

Kingsport-Longview contact-_. 70

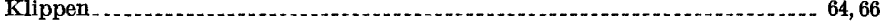

Knox dolomite. . . .

Knox group . .

history of terminology

present usage

recent work. . . . .

ridges........... $55-56$

unconformity at top of....... 23-24

work before 1929

Koppick Knob

$\mathbf{L}$

Laurence, R. A., color measurements. _ _ _ _

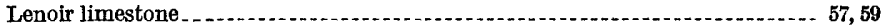

description

fossils.............. 60

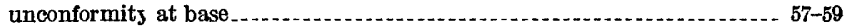

See also Mosheim member.

Location of area............................................ 1

Lochman, Chr istina, quoted................. 20

Longview dolomite correlation

description ............ 46-49

distribution of species. . . .

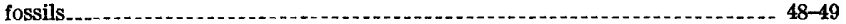

relation to Chepultepec dolomite.

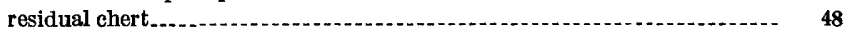

Mapping procedures

Maryville limestone

description - . .

facies relationships..... 17-18

topographic expression

Mascot belt..... $7,9,10,12,21,26,38,61-62,63,69,71,72$

Mascot dolomite..................................................... 23, 55, 56, 57-58;72 correlation -

description. . .

relief on surface

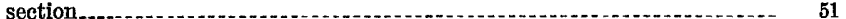

Maynardville limestone member of Nolichucky shale................ 7, 8, 53, 61, 72 Aphelas pis fauna. description . . .

Loves Creek section. . . .

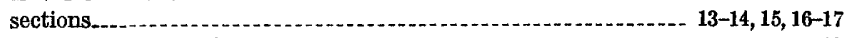

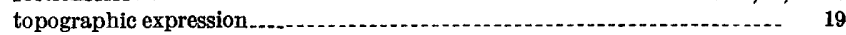

Mill Spring thrust fault. ............................... 7, 61, 62, 63, 64 68, 71, 72

Mines, Athletic. ................. 69 Davis distribution . . . 
Mines-Continued

Page

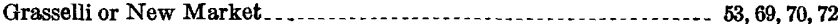

Jarnagin

Mascot_................. 47, 69, 71

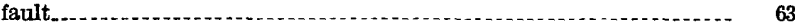

Mossy Creek

Rocky Valley fault through. . ......... 66,70

North Friends Station................ 72

Young -

Moccrsin Ridge.

Moore, E. S., quoted.

Mosheim anticline

Mosheim member of Lenoir limestone ___ 57, 58 description . .

$\mathbf{N}$

Nolichucky shale............ 7, 8. 61, 72 description . . . .

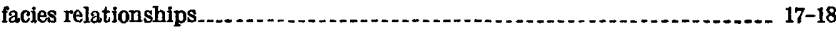

faunal zones $\ldots$

Loves Creek section ............. 29-30

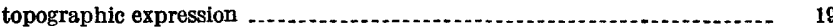

See also Maynardville limestone member.

Norris Dam

Norris Lake.

Oder, C. R. L., quoted.

Ore-bearing zone of sphalerite

$P \quad$ 24-25
names and distribution................ 7-8 Prospects, distribution . . . . Pumpkin Valley shale ....................................................... 8, 30

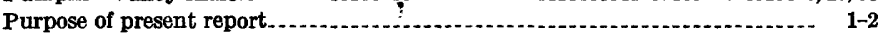

$\mathbf{Q}$

Quarries, Biagiotti............ 17 Craig Knox County at Tecoy

Knox County workhouso

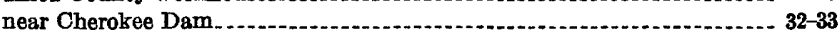

Owl Hole Gap, veinlets of sphalerite.

State Highway Department

TVA

Quartz cavity-fillings, Chepultepec dolomite

"Recrystalline" dolomite. ore bodies.

Relief, of the area

on surface of Mascot dolomite.

Resser, C. E., quoted.

Richland fault

escarpment $10,15,19$

Ridges, description . . . .

Roads, county

Rock structure, mechanics.

Rocks of the Appalachian Valley

Rocky Valley anticline.

$9,40,66,67,68-69$

material in crest

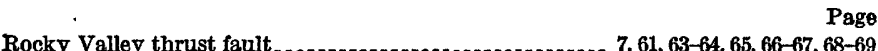
gersville shale

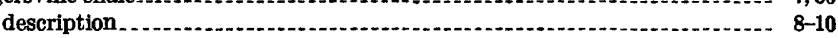
facies relationships...... 17-18

topographic expression

See also Craig limestone member.

Rome formation

ridges ............... 55-56, 62

topographic expression

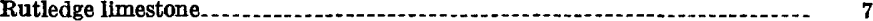

description . . . . .

facies relationships.

topographic expression

$\mathbf{s}$

Safford, J. M., quoted

$21,40,56$

$7,29,30,61,62,67,68,69$

Sandstone, residual ........................................................ $33,41,48,54,55$

Scope of present report. . . . .

Shady dolomite.

Shields Ridge

Shields Ridge belt........ 7.8, 38, 61, 66-67

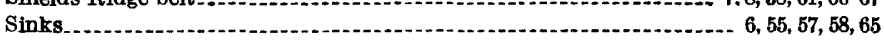

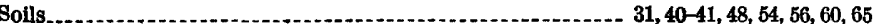

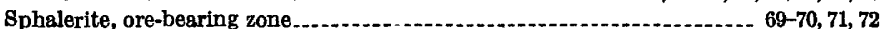

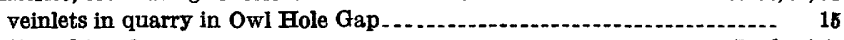

Stratigraphic columns............................................... 7; chart 1.

Stratigraphy _ 7-60

Strawberry Plains basin.

Structural belts...................... $55-56,61-68$

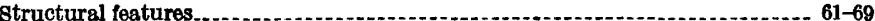

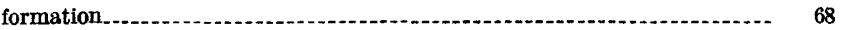

Synclines, between Cherokee and Rocky Valley anticlines................... 65 east of Jefferson City. . . . . . .

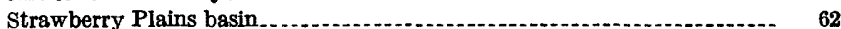

$\mathrm{T}$

Tennessee Co\&l \& Iron Division, U. 8. 8teel, mines.......................... 69, 71 Tennessee Valley Authority, Geologic Division, work in East Tennessee ....... 4

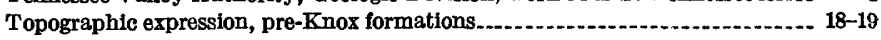

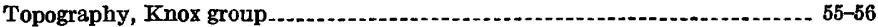

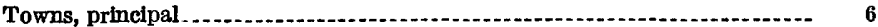

Troughs, parallel

$11,24,34,37,40$

Unconformity, at base of Lenoir limestone_.................. 57-59

at top of Canadian or Lower Ordovician

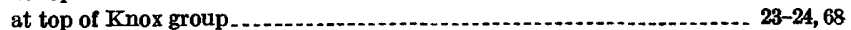

$\boldsymbol{V}$

Veinlets of sphalerite in quarry in Owl Hole Gap

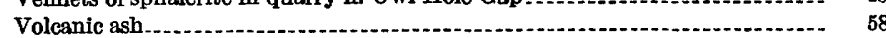

W

Wilson, J. L., quoted

Work before 1929

$\mathbf{Z}$ 